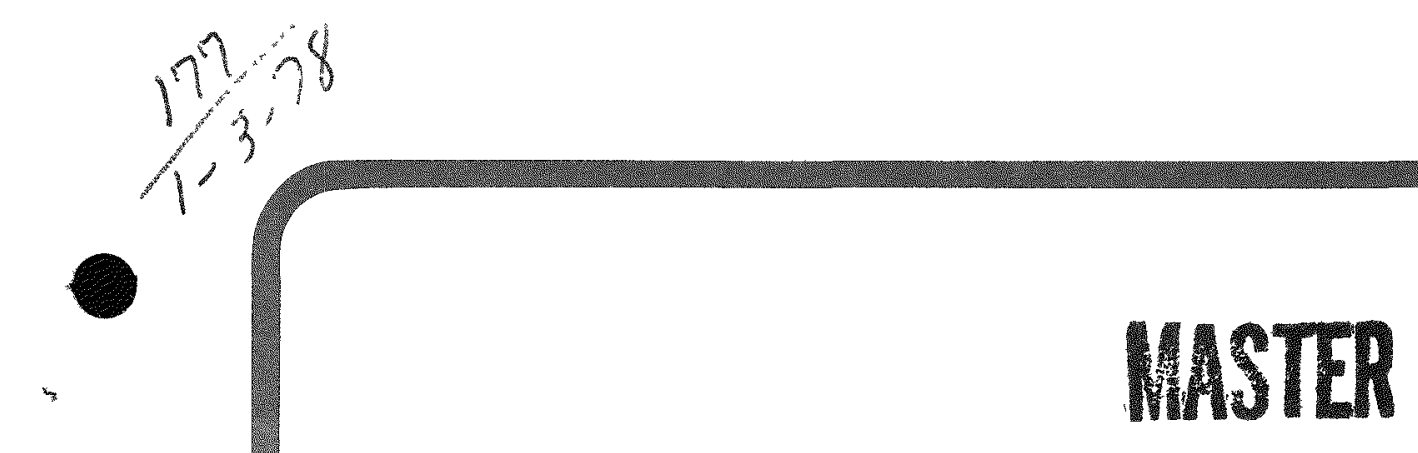

\title{
REPROCESSING FLOWSHEET AND MATERIAL BALANCE FOR MEU SPENT FUEL
}

\author{
by \\ L. ABRAHAM
}

Prepared under

Contract EY-76-C-03-0167

Project Agreement No. 53

for the San Francisco Operations Office

Department of Energy

DATE PUBLISHED: OCTOBER 1978 


\section{NOTICE}

This report was prepared as an account of work sponsored by the United States Government. Neither the United States nor the Department of Energy, nor any of their employees, nor any of their contractors, subcontractors, or their employees, makes any warranty, express or implied, or assumes any legal hiability or responsibility for the accuracy, completeness or usefulness of any information, apparatus, product or process disclosed, or represents that its use would not infringe privately owned rights.

Printed in the United States of America Available from

National Technical Information Service

U.S. Department of Commerce

5285 Port Royal Road

Springfield, Virginia 22161

Price: Printed Copy $\$ 5.25$; Microfiche $\$ 3.00$ 


\section{DISCLAIMER}

This report was prepared as an account of work sponsored by an agency of the United States Government. Neither the United States Government nor any agency Thereof, nor any of their employees, makes any warranty, express or implied, or assumes any legal liability or responsibility for the accuracy, completeness, or usefulness of any information, apparatus, product, or process disclosed, or represents that its use would not infringe privately owned rights. Reference herein to any specific commercial product, process, or service by trade name, trademark, manufacturer, or otherwise does not necessarily constitute or imply its endorsement, recommendation, or favoring by the United States Government or any agency thereof. The views and opinions of authors expressed herein do not necessarily state or reflect those of the United States Government or any agency thereof. 


\section{DISCLAIMER}

Portions of this document may be illegible in electronic image products. Images are produced from the best available original document. 


\title{
REPROCESSING FLOWSHEET AND MATERIAL BALANCE FOR MEU SPENT FUEL
}

\author{
by \\ L. ABRAHAM \\ Prepared under \\ Contract EY-76-C-03-0167 \\ Project Agreement No. 53 \\ for the San Francisco Operations Office \\ Department of Energy
}

GENERAL ATOMIC PROJECT 3261

DATE PUBLISHED: OCTOBER 1978 
-

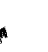
. . 


\begin{abstract}
In response to nonproliferation concerns, the high-temperature gas-cooled reactor (HTGR) Fuel Recycle Development Program is investigating the processing requirements for a denatured medium-enriched uranium-thorium (MEU/Th) fuel cycle. Prior work emphasized the processing requirements for a high-enriched uranium-thorium (HEU/Th) fuel cycle.

This report presents reprocessing flowsheets for an HTGR/MEU fuel recycle base case. Material balance data have been calculated for reprocessing of spent MEU and recycle fuels in the HTGR Recycle Reference Facility (HRRF). Flowsheet and mass flow effects in MEU-cycle reprocessing are discussed in comparison with prior HEU-cycle flowsheets.
\end{abstract}


-

$-4$

- 
CONTENTS

ABSTRACT . . . . . . . . . . . . . . . . . . $i i i$

1. INTRODUCTION ...................... . . . . . 1

2. MEU FUEL RECYCLE BASE CASE ................. . . . 2

2.1. Fue1 Cycle Description ............. 2

2.2. Fuel Element Description ............ 8

2.3. Reprocessing Flowsheet Scheme . . . . . . . . 8

3. IMPACT OF MEU FUEL REPROCESSING FLOWSHEET ON HRRF DESIGN • • 14

3.1. HRRF-Reprocessing Design Assumptions . . . . . . . . 14

3.2. HRRF Reprocessing Operating Mode .......... 15

4. FLOWSHEET AND MATERIAL BALANCE UPDATE . . . . . . . . 17

4.1. Characteristics of Spent HTGR Fuels in the MEU Cycle . 17

4.2. Flowsheet Update for MEU-Cycle Reprocessing . . . . . 21

4.3. Material Balance Update for MEU-Cycle Reprocessing . . 23

5. SUMMARY AND CONCLUSIONS . . . . . . . . . . . . 29

ACKNOWLEDGMENTS . . . . . . . . . . . . . . . . 30

REFERENCES ........................ 31

APPENDIX A: HRRF REPROCESSING FLOWSHEETS FOR MEU-CYCLE FUELS

APPENDIX B: HRRF REPROCESSING MATERIAL BALANCE DATA FOR MEUCYCLE FUELS

FIGURES

1. HTGR standard fuel element . . . . . . . . . . . 9

2. HTGR coated fuel particles . . . . . . . . . . . 10

3. HTGR/MEU fuel recycle base case reprocessing flowsheet . . . 12 
1. Recycle base case fuel cycle definition and desirable flexibilities................... 3

2. Characteristic HTGR core parameters ............. 4

3. Equilibrium $M$ fuel element summary . . . . . . . . . . 5

4. Equilibrium 23R fuel element summary ........... 6

5. Supplemental equilibrium fuel characteristics . . . . . . 7

6. Spent fuel element definition for average HTGR standard makeup element - MEU cycle . . . . . . . . . . 18

7. Spent fuel element definition for average HTGR standard U-233 recycle element - MEU cycle . . . . . . . . . 19

8. Plutonium content in spent MEU-cycle fuels . . . . . . . 20

9. Radiological characteristics of equilibrium spent fuels . . . 20

10. Spent fuel definitions for makeup elements . . . . . . . 25

11. Spent fuel definitions for recycle fuels . . . . . . . . 26

12. Equilibrium makeup fuel element summary . . . . . . . . 28 


\section{INTRODUCTION}

The principal fuel cycle considered for commercialization of the high-temperature gas-cooled reactor (HTGR) has generally been the highenriched uranium-thorium (HEU/Th) fuel cycle. Recent governmental policy pronouncements and heightened concerns about safeguards for minimizing the weapons proliferation potential of nuclear fuel cycles have stimulated interest in operation of the HTGR on a denatured uranium-thorium fuel cycle. Therefore, the HTGR Fuel Recycle Development Program (Ref. 1) has been redirected to address the recycle requirements for a mediumenriched uranium-thorium (MEU/Th) fuel system. The MEU cycle (approximately $20 \%$ enriched fissile uranium two-particle proliferation-resistant fuel) is the current reference fuel cycle for HTGR recycle development, while HEU (approximately 93\% fissile) and LEU (low-enriched, approximately $9 \%$ fissile) are designated the first and second alternates, respectively.

The MEU HTGRs are fueled initially with fissile particles that contain about $20 \% \mathrm{U}-235$ in $\mathrm{U}-238$, plus $\mathrm{ThO}_{2}$ fertile particles. This reactor cycle meets the presently postulated nonproliferation criterion that the risk of surreptitious use of strategic nuclear materials from its fresh or spent fuel will be equivalent to or less than that from present LWR spent fuel.

The technology for reprocessing spent fuel for the MEU cycle is similar to that for the HEU cycle, requiring relatively minor adjustments in the reprocessing flowsheets but resulting in changed mass flows and material balances for the reprocessing system flowsheets. This report updates the reprocessing flowsheet for the HTGR MEU fuel recycle base case and summarizes the material balance for the HTGR Recycle Reference Facility (HRRF) reprocessing plant. 


\section{MEU FUEL RECYCLE BASE CASE}

\subsection{FUEL CYCLE DESCRIPTION}

A reference MEU/Th cycle with nondenatured U-233 recycle in the HTGR was selected as the basis for spent fuel composition calculations for the HRRF reprocessing material balance update. The recycle of nondenatured U-233 is based on the assumption that its gamma activity in conjunction with engineered safeguards fuel cycle design features will be a sufficient deterrent against special nuclear material (SNM) diversion. The savings in $\mathrm{U}_{3} \mathrm{O}_{8}$ requirements achieved by not denaturing the recycle $\mathrm{U}-233$ with U-238 are of the order of $12 \%$. Additional savings of $6 \%$ are achieved by using continuous rather than once-through recycle (Ref. 2).

The MEU fuel recycle base case, including flexibility options to be considered during the course of later HRRF engineering feasibility studies, was approved as the FY-78 reference for HRRF studies and requirements definition (Refs. 3, 4). The flexibility options will also be evaluated in reactor optimization and nonproliferation assessment studies. Table 1 summarizes the recycle base case fuel cycle definition and desirable flexibilities as originally approved. Table 2 summarizes characteristic HTGR core parameters that evolved from subsequent iterative computer code calculations, which established equilibrium spent fuel compositions for MEU makeup fuel elements and for U-233 recycle elements (Ref. 5). An equilibrium core reload segment for a 1330-MW(e) HTGR will include 872 MEU makeup elements and 450 nondenatured U-233 recycle elements.

Core-averaged compositions of MEU makeup fuel elements (M) and of $\mathrm{U}-233$ recycle elements (23R) are defined in Tables 3 and 4, respectively, and fuel particle characteristics for makeup and recycle elements are summarized in Table 5, taken from Ref. 5. The MEU/Th fuel cycle, 
TABLE 1

RECYCLE BASE CASE FUEL CYCLE DEFINITION AND DESIRABLE FLEXIBILITIES

\section{Typical Recycle Case Characteristic}

Power density
Power leve1
Refueling frequency
Fuel lifetime
Annual capacity factor
U-233 recycle mode

Makeup fissile particle disposition

$7.1 \mathrm{~W} / \mathrm{cm}^{3}$
$3360 \mathrm{MW}(\mathrm{t})$
$1.0 \mathrm{yr}$
$4.0 \mathrm{yx}$
$80 \%$
Recycle of HEU-233 at
reload 2
No denaturing

No recycle; stowaway for

U recovery

\begin{tabular}{|c|c|c|}
\hline $\begin{array}{l}\text { Initial core } \\
\text { Reload }\end{array}$ & $\begin{array}{l}350^{(a)} \\
850^{(a)}\end{array}$ & \\
\hline $\begin{array}{l}k_{\text {eff }} \text { end-of-cycle } \\
\text { Fuel element (stand }\end{array}$ & 1.01 & \\
\hline No. of fuel holes & 138 & \\
\hline Fue1 pin diameter & $1.17 \mathrm{c}$ & $0.46 \mathrm{in.}$ \\
\hline Fue1 particles & & \\
\hline MEU-235 fissile p & icle (dense & O TRISO) \\
\hline Dimensions for $\mathrm{ME}$ & & \\
\hline & $\begin{array}{l}\text { Thickness } \\
(\mu \mathrm{m})\end{array}$ & $\begin{array}{c}\text { Radius } \\
(\mu \mathrm{m})\end{array}$ \\
\hline Kernel. & $-\infty$ & $175(a)$ \\
\hline Buffer & $105(a)$ & $280^{(a)}$ \\
\hline IPyC & 35 & 315 \\
\hline $\mathrm{SiC}$ & 35 & 350 \\
\hline $\mathrm{OPyC}$ & 45 & 395 \\
\hline
\end{tabular}

U-233 fissile particle

Thorium particle
Current reference HTGR HEU WAR recycle particle

Current reference HTGR fertile particle

Desirable Flexibility

2200

$-$

60 to 80

Recycle $12 \%$ to $15 \%$ MEU-233 at reload 2 or later reload

Denature in reprocessing plant with natural $U$ or irraduated $U$

In-situ denaturing with natural U or MEU

Stowaway for U-235 and $\mathrm{Pu}$ recovery

Recover $U$ and blend with HEU-233 to denature U-233

Reenrich U and recycle a11 U-235 in HTGR; recycle $\mathrm{Pu}$ in FBR or LWR Reenrich discharge U with HEU and recycle in HTGR

Capability for HEU-235 and HEU-233 fuel types

$150 \rightarrow \infty$ (HEU to LEU)

$150 \rightarrow \infty$ (HEU to LEU)

1.00 to 1.01

138 or 210

$1.0 \mathrm{~cm}$ to $1.6 \mathrm{~cm}$ $\mathrm{UO}_{2}, \mathrm{UC}_{2}$, doped BISO Dimensions for MEU:

\begin{tabular}{|c|c|}
\hline $\begin{array}{l}\text { Thickness } \\
\text { ( } \mathrm{\mu m})\end{array}$ & $\begin{array}{l}\text { Radius } \\
\text { (jtm) }\end{array}$ \\
\hline-- & $170-200$ \\
\hline $70-120$ & -- \\
\hline 35 & -- \\
\hline 35 & -- \\
\hline 45 & -- \\
\hline
\end{tabular}

Dense UCO same as MEU-235 fissile

Doped BISO

\footnotetext{
(a) Indicated typical value may change as a result of optimization for HEU-233 recycle.
} 
TABLE 2
CHARACTERISTIC HTGR CORE PARAMETERS (a)

Parameter

Thermal power

Electrical power

Fuel elements/core

Fuel elements/segment

$M$ type elements/segment

(at equilibrium)

23R type elements/segment

(at equilibrium)

Carbon/thorium ratio

(initial core)

Carbon/thorium ratio

(reload 1)

Carbon/thorium ratio

(remainder of cycle)

Fuel rod diameter (initial

core and reload 1 )

Fuel rod diameter

(remainder of cycle)

Fuel rod stack length

(entire cycle)

Fuel rod length (entire cycle)

Fuel holes/standard element

Fuel holes/control element

Thermal power density
Value

$3360 \mathrm{MW}(\mathrm{t})$

$1330 \mathrm{MW}(\mathrm{e})$

5288

1322

872

450

355

1175

400

$11.7 \mathrm{~mm}$

$14.0 \mathrm{~mm}$

$781.6 \mathrm{~mm}$

$65.1 \mathrm{~mm}$

138

82

$7.1 \mathrm{~W} / \mathrm{cm}^{3}$

(a) Indicated typical values may change as a result of optimization for $\mathrm{HEU}-233$ recycle. 
TABLE 3

EQUILIBRIUM M FUEL ELEMENT SUMMARY

(Core-Averaged, As Charged)

\section{Component}

Fissile particles

$\left(\rho=2.64 \mathrm{~g} / \mathrm{cm}^{3}\right)$

Outer PyC coating

SiC coating (1.85 $\mathrm{kg} \mathrm{Si})$

Inner PyC coating

Buffer coating

Kernel (UCO;

$\left.\rho=10.6 \mathrm{~g} / \mathrm{cm}^{3}\right)$

Total U (kernel)

$\left\{\begin{array}{c}80.2 \% \mathrm{U}-238 \\ 19.8 \% \mathrm{U}-235 \\ \text { by mass }\end{array}\right\}$

Total C (kernel)

Total O (kernel)

Fertile particles

$\left(\rho=3.44 \mathrm{~g} / \mathrm{cm}^{3}\right)$

Outer PyC coating

Buffer coating

Kerne1 ( $\mathrm{ThO}_{2} ; \rho=9.9 \mathrm{~g} / \mathrm{cm}^{3}$ )

Total Th (kernel)

Total o (kerne1)

Graphite block (includes

the plugs, dowels, matrix, and shim)

Boron

Total mass
Mass

(kg/fuel element)

11.42

2.35

2.64

1.24

1.22

3.97

3.55

0.18

0.24

9.00

2.25

0.87

5.88

5.16

0.72

97.52

0.01

117.95 
TABLE 4

EQUILIBRIUM 23R FUEL ELEMENT SUMMARY

(Core-Averaged, As Charged)

\section{Component}

Fissile particles

$\left(\rho=2.16 \mathrm{~g} / \mathrm{cm}^{3}\right)$

Outer PyC coating

SiC coating $(0.86 \mathrm{~kg} \mathrm{Si})$

Inner PyC coating

Buffer coating

Kernel (WAR UCO;

$\left.\rho=3.3 \mathrm{~g} / \mathrm{cm}^{3}\right)$

Tota1 U (kerne1)

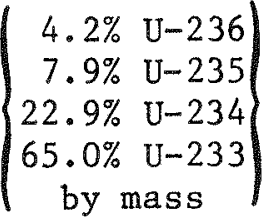

Total C (kernel)

0.04

Tota1 o (kernel)

0.05

Fertile particles

$\left(\rho=3.44 \mathrm{~g} / \mathrm{cm}^{3}\right)$

Outer PyC coating

9.00

Buffer coating

2.25

Kernel ( $\left.\mathrm{ThO}_{2} ; \rho=9.9 \mathrm{~g} / \mathrm{cm}^{3}\right)$

0.87

Total Th (kernel)

5.88

Total 0 (kernel)

5.16

Graphite block (includes the

0.72

plugs, dowels, matrix, and

shim)

Boron

Total mass

0.01

100.93

113.90 
TABLE 5
SUPPLEMENTAL EQUILIBRIUM FUEL CHARACTERISTICS $(a, b)$

\begin{tabular}{cc}
$\begin{array}{c}\text { Dimensional. } \\
(\mu \mathrm{m})\end{array}$ & $\begin{array}{l}\text { Density } \\
(\mathrm{g} / \mathrm{cm})\end{array}$ \\
\hline
\end{tabular}

Makeup fissile

Kernel (UCO)
Buffer
IPyC
SiC
OPyC
Total particle
$t / D(c)$

$\begin{array}{ll}350 \text { diameter } & 10.6 \\ 105 \text { thickness } & 1.05 \\ 35 \text { thickness } & 1.9 \\ 35 \text { thickness } & 3.2 \\ 45 \text { thickness } & 1.8 \\ 790 \text { diameter } & \\ 0.63 & \end{array}$

Recycle fissile

Kernel (WAR UCO)
Buffer
IPyC
SiC
OPyC
Total particle
t/D
360 diameter
65 thickness
35 thickness
35 thickness
40 thickness
710 diameter
0.486

3.3

1.05

1.9

3.2

Makeup and recycle fertile

Kernel $\left(\mathrm{ThO}_{2}\right)$
Buffer
PyC
Total particle
t/D

$\begin{aligned} 500 \text { diameter } & 9.9 \\ 85 \text { thickness } & 1.05 \\ 75 \text { thickness } & 1.90 \\ 820 \text { diameter } & \\ 0.195 & \end{aligned}$

(a) From Ref. 5.

(b) At fuel cycle equilibrium, the fuel particle packing fractions for makeup and recycle fuel rods are assumed to be $\sim 50 \%$ and $225 \%$, respectively.

(c) $t / D=$ thickness/diameter. 
applied in a recycle mode, employs a two-particle fuel system. Typically, the fissile particle may be TRISO coated dense UCO or UC $\mathrm{UC}_{2}$ for makeup fuel and TRISO coated weak acid resin-derived (WAR) $\mathrm{UC}_{\mathrm{x}} \mathrm{O}_{\mathrm{y}}$ for recycle fuel. The fertile particle is typically BISO coated $\mathrm{ThO}_{2}$.

\subsection{FUEL ELEMENT DESCRIPTION}

The standard fuel element in the HTGR is a graphite block $79.3 \mathrm{~cm}$ (31.4 in.) high with a hexagonal cross section $35.9 \mathrm{~cm}(14.2 \mathrm{in.})$ across the flats, as illustrated in Fig. 1. The graphite block is drilled lengthwise with two sets of holes; one allows the passage of helium coolant, and the second contains the fuel rods. Fuel rods contain selected blends of fuel and graphite shim particles in a carbonaceous matrix. Each fuel rod is $6.5 \mathrm{~cm}(\sim 2.5 \mathrm{in}$.$) in length and typically has a diameter of 1.40 \mathrm{~cm}$ (0.554 in.). The fuel particles used in the HTGR, shown schematically in Fig. 2, typically have diameters of 500 to $800 \mu \mathrm{m}$.

Two particle types are used in the HTGR fuel; they are categorized by the coatings that have been applied to them (see Fig. 2). BISO particles are coated with a relatively porous buffer layer of carbon and then with a dense coating of pyrolytic carbon. TRISO coatings, in addition, have a silicon carbide coating placed between two layers of pyrolytic carbon. The SiC layer provides a means of separating these particles from the BISO particles in head-end reprocessing operations; it also enhances fission product retention in the fissile particles. BISO coatings are used for particles initially loaded only with thorium oxide, while TRISO coatings are used for particles loaded with uranium in the form of UCO or $\mathrm{UC}_{2}$.

\subsection{REPROCESSING FLOWSHEET SCHEME}

The use of discrete fissile and fertile particles in the MEU/Th

fuel cycle permits separation of spent fissile fuel values (e.g., U-235 in the case of initial and makeup elements) from fertile particles which 


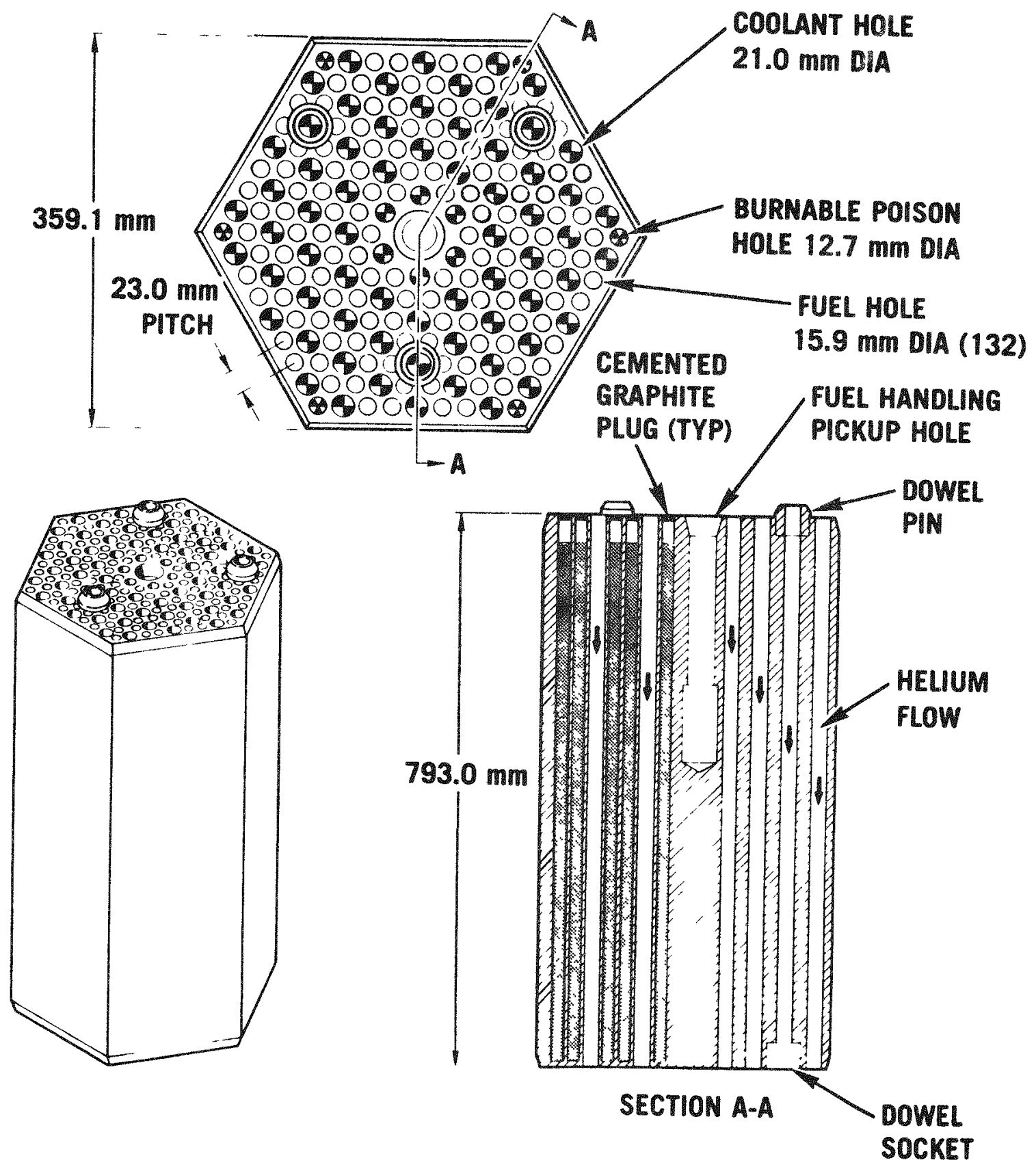

Fig. 1. HTGR standard fuel element 


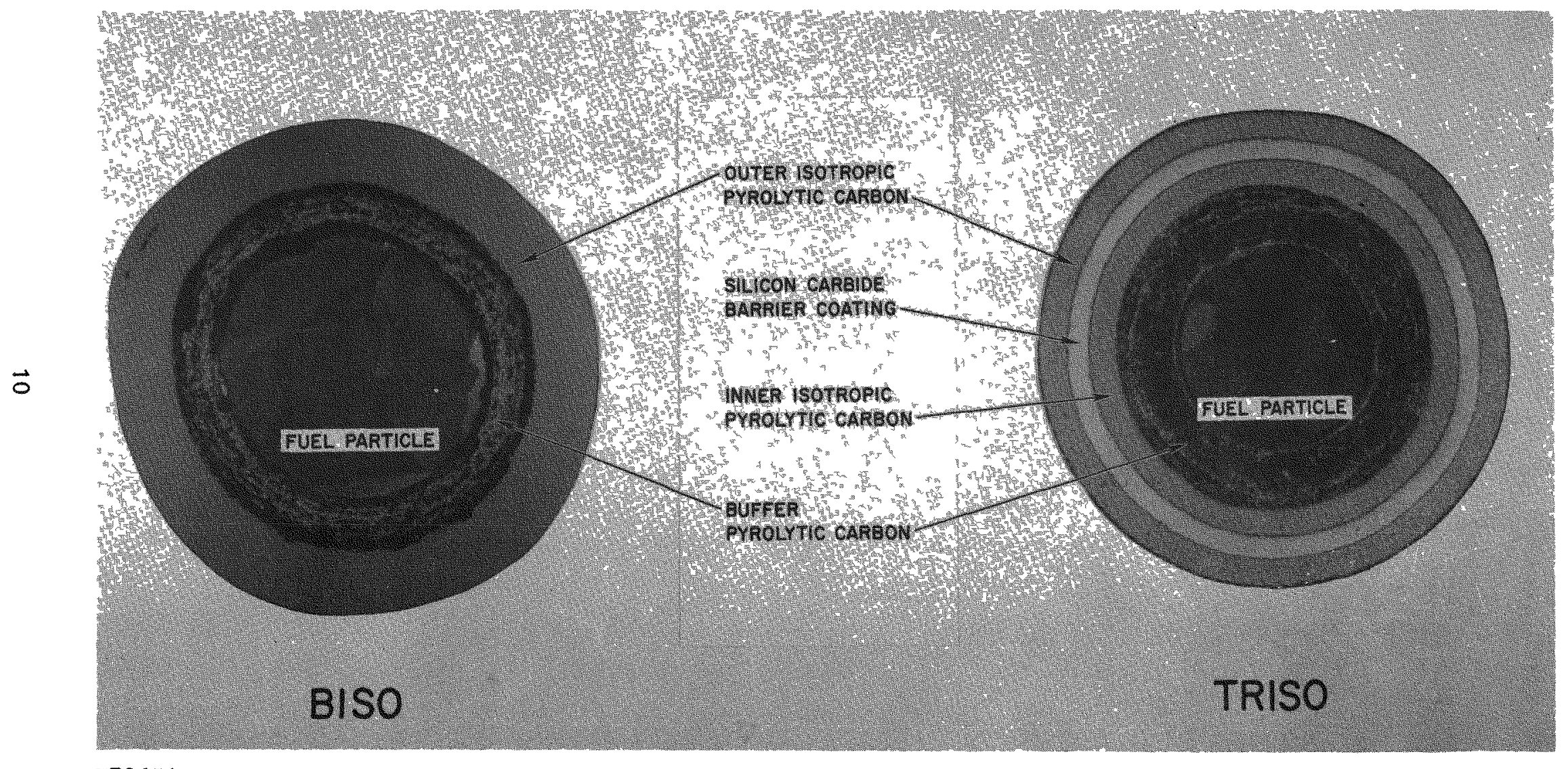

K72654

Fig. 2. HTGR coated fuel particles 
contain bred U-233, thereby minimizing contamination of the high-quality bred fuel values. The separability of the fissile and fertile fuel particle types is also highly advantageous for proliferation resistance in MEU/Th fuel recycle, since plutonium bred in the MEU makeup fissile fuel may be disposed of as SiC-coated spent fissile particles without ever being separated from fission products or from spent uranium.

In the proposed MEU fuel cycle reprocessing scheme, fissile particles obtained from U-233 recycle elements are processed to recover the residual U-233 values. In contrast to spent makeup element fissile particles, the spent recycle fissile particles are not attractive as a source of fissionable plutonium, since they contain only $1.2 \mathrm{~g}$ of plutonium per fuel element, with approximately $85 \%$ of the plutonium being nonfissionable Pu-238 (Ref. 5). The reprocessing option selected for the MEU fuel recycle base case, therefore, involves (1) separation and disposal of initial and makeup element (I,M) fissile particles; (2) full reprocessing of recycle element (23R) fissile particles, and (3) full reprocessing of fertile particles from both $I, M$ and $23 R$ fuel elements.

A reprocessing flowsheet schematic for the MEU fuel recycle base case is shown in Fig. 3. Separation of fissile and fertile fuel particles from spent fuel elements is accomplished by the head-end process system, which entails primarily a crush-burn-leach sequence. The spent fuel elements are crushed in a three-stage size reduction unit to provide feed material for a fluidized-bed primary burner. Combustion in the burner removes the fuel element graphite moderator and outer carbon coating of the fuel particles by conversion to $\mathrm{CO}_{2}$. The remaining fuel particles are separated into SiC-coated fissile and burned-back fertile particle fractions by pneumatic classification. The burned-back BISO coated fertile particle fraction is dissolved in a nitric acid solution containing a fluoride catalyst. The leachate is clarified from insolubles by centrifugation and routed to a feed adjustment step to prepare the solution for subsequent Acid Thorex solvent extraction processing. Solvent extraction removes fission products and separates U-233 from thorium. 


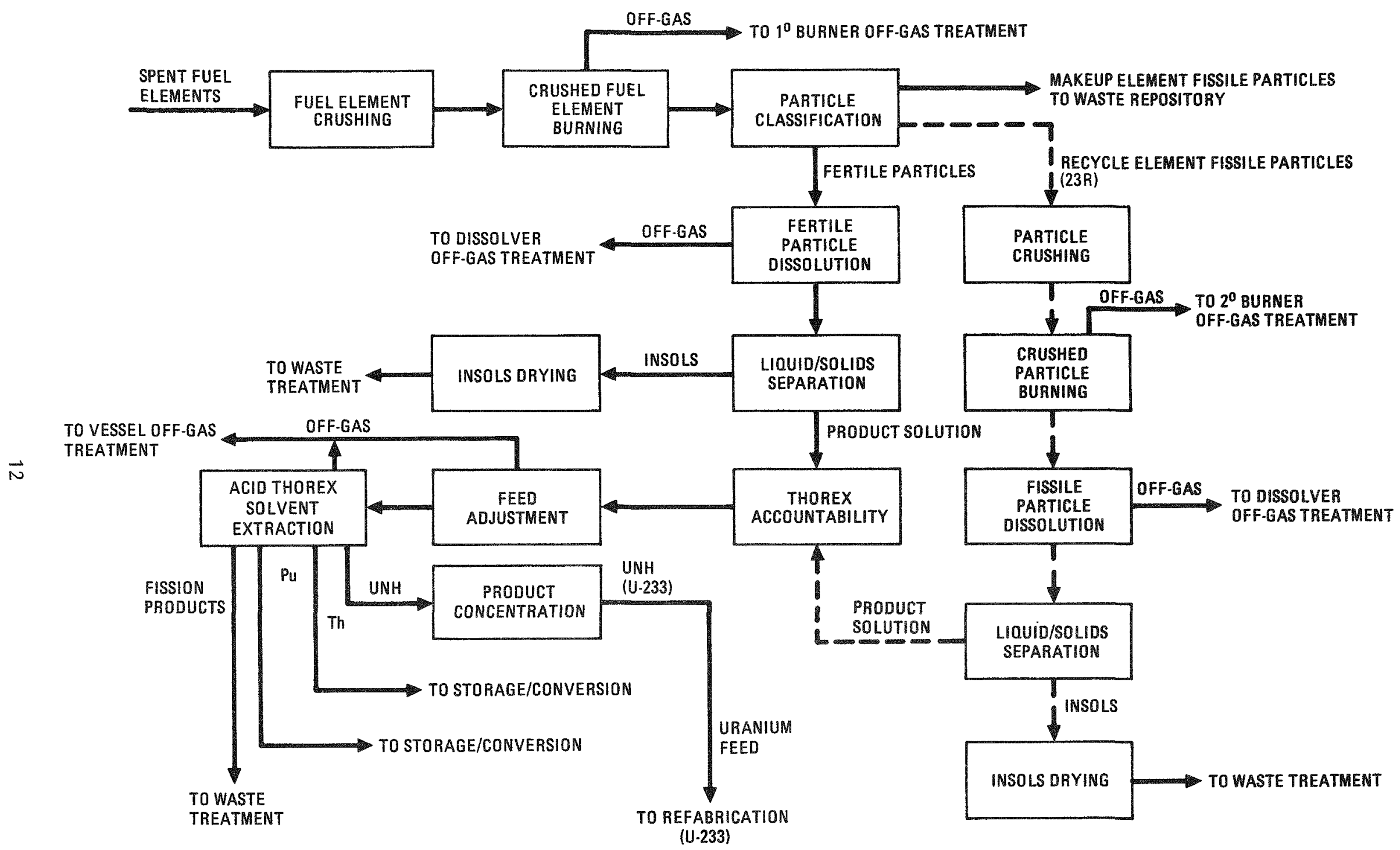

Fig. 3. HTGR/MEU fuel recycle base case reprocessing flowsheet 
The partially burned-back TRISO coated fissile particle fraction is further processed in one of two alternate ways, depending on the source spent fuel element type. Fissile particles from initial or makeup $(I, M)$ elements are immobilized in an inert matrix and packaged for later isolation in a waste repository. Burned-back TRISO coated fissile particles from U-233 recycle (23R) elements are crushed to crack the protective SiC layer and to expose the inner carbon coating. The carbon combustion and removal process is completed in a fluidized-bed secondary burner. The fissile ash from the secondary burner is dissolved in nitric acid solution, and insolubles are removed by centrifugation. The clarified leachate is combined with U-233-containing leachate obtained from fertile particle dissolution for further processing through feed adjustment and Acid Thorex solvent extraction. 


\section{IMPACT OF MEU FUEL REPROCESSING FLOWSHEET ON HRRF DESIGN}

\subsection{HRRF-REPROCESSING DESIGN ASSUMPTIONS}

The HRRF will be designed to reprocess 20,000 spent fuel elements per year. At equilibrium, the distribution of spent HTGR fuel elements to be processed is currently estimated to be $66 \%$ makeup elements (MS) which use $20 \%$ enriched U-235-containing fissile particles, and $34 \%$ recycle elements (23RS) which use nondenatured U-233-containing fissile particles. In contrast to prior HEU cycle reprocessing flowsheets, the MEU fuel recycle base case does not postulate recovery of residual U-235 fuel. values; thus, the need for HRRF to reprocess $U-235$ recycle elements is eliminated.

As currently envisioned, spent MEU fuel originating at the Fort St. Vrain reactor will not be reprocessed but will be stored at a federal repository in spent fuel form. Spent HEU fuel originating at FSV will, however, be campaigned through HRRF reprocessing if permitted by national policy. Similarly, HRRF will provide a capability for reprocessing of very low burnup HTGR makeup fuel elements which may not have been fully irradiated owing to premature discharge from a reactor. In this case, it is intended to recover the $20 \%$-enriched fissile material (U-235). Therefore, HRRF will include Purex solvent extraction process capability, even though the MEU cycle flowsheet indicates no need for Purex. Finally, HRRF will reprocess scrapped refabricated U-233 fuel elements on a campaign basis, after sufficient rejects have been accumulated in a dedicated scrap refabricated fuel storage area. It is important to note that HRRF will reprocess only spent initial and makeup fuel elements for approximately the first 5 years of operation, since spent recycle fuel will not be discharged from an HTGR prior to that time. 
The HRRF will reprocess a number of HTGR fuel element types, e.g., standard, contro1, and buffer elements. Standard elements contain more fuel than do the other types. For the purpose of defining the daily throughput requirements for HRRF reprocessing, a core-averaged standard spent fuel element has been postulated and is used as the basis for material balance calculations. Daily throughput requirements for HRRF reprocessing are further defined by an interim design ground rule which assumes an overall reprocessing system availability of $80 \%$ and equipment utilization efficiency of $90 \%$. The design ground rule also includes a 30-day-per-year allowance for customer accountability sweepdown and sampling operations in the head-end system.

On this basis, the head-end process system will have a design capacity for 86 elements per day, 233 days per year. The solvent extraction system will process the output from head-end operations in a period of 263 days per year. More specifically, the design capacity for fuel element crushing, primary burning, particle classification, and fertile particle dissolution subsystems will be based on processing 86 spent makeup elements (MS) per day; the design capacity for particle crushing, crushed particle burning, and fissile particle dissolution subsystems will be based on processing 86 spent recycle elements (23RS) per day; and, finally, the Acid Thorex solvent extraction system must have a throughput capacity sufficient to process the combined U-233 solution outputs from fertile and fissile particle dissolution.

\subsection{HRRF REPROCESSING OPERATING MODE}

The head-end system of HRRF reprocessing is designed to operate semicontinuously during processing of a customer's spent fuel lot, which is assumed to typically correspond to a reactor half-segment, or approximately 440 elements for a 900-MW(e) HTGR. The half-segment operating mode reduces fuel storage requirements by allowing processing to begin before spent fuel shipping for a customer is completed. Customer accountability requirements are satisfied by campaign processing of a customer's fuel 
elements, daily sampling of accountability tanks, and a final sweepdown of the head-end system at the completion of each customer's spent fuel 1ot. An important operating mode basis is that the integrity of a customer's fuel material is maintained only through the accountability step. After that, intermixing with material from other customers' lots may occur.

The duration of batch operations during head-end processing of a customer's spent fuel 1ot is principally determined by the operating characteristics and cycles of key processing subsystems, such as the crushed fuel element (primary) burner, crushed fuel particle (secondary) burner, or fertile particle dissolver. Surge capacity will be provided between subsystems in the HRRF head-end process system to (1) provide a degree of flexibility, (2) provide a degree of subsystem/process decoupling, (3) make head-end system operation less sensitive to operating upsets or equipment failure, and (4) approach an essentially continuous operating mode to as high a degree as practical.

Surge storage for head-end leachate will be provided to permit continuing operation of the solvent extraction system during periods of head-end sweepdown or other downtimes. In the solvent extraction system, separate solvent extraction trains will be used to ensure a continuous processing capability and to minimize surge requirements.

The HRRF reprocessing off-gas systems will be designed to accommodate treatment of all gaseous effluents from dry and wet head-end processing. A continuous sidestream from the transport gas system will be treated in the primary burner off-gas system. Avallability of the off-gas treatment systems must be assured for operation 365 days per year. Installation of parallel processing units, e.g., to permit off-stream regeneration of an adsorber bed while a like parallel unit is placed on-stream, and other appropriate design features will be used to achieve the availability goal. 


\section{FLOWSHEET AND MATERIAI BALANCE UPDATE}

\subsection{CHARACTERISTICS OF SPENT HTGR FUELS IN THE MEU CYCLE}

As pointed out in the HRRF reprocessing design assumptions (Section 3.1), fuel element configurations differing somewhat from the standard element will also be reprocessed in the HRRF. However, variations in fuel element composition are considered to be a more important reprocessing parameter than is the geometric configuration of the element. In the HEU fuel cycle, fissile uranium constitutes the valuable inventory of the reprocessing plant, from the standpoint of both fuel cycle economics and regulations for safeguarding of special nuclear material (SNM). In the MEU fuel cycle, the presence of fissionable plutonium in spent makeup element fissile particles also contributes to SNM safeguards concerns. Other heavy metal and fission product content affects the operational characteristics and throughput of several processes, particularly in solvent extraction, off-gas processing, and waste treatment.

The MEU-cycle feed materials for the reprocessing plant are typified by the equilibrium spent fuel element definitions summarized in Tables 6 and 7 taken from Ref. 5). Table 6 presents the design-basis spent fuel definition for MEU-cycle makeup elements (MS), and Table 7 presents the corresponding information for MEU-cycle U-233 recycle elements (23RS). The total plutonium contents and isotopic distrubutions for these two types of spent fuel elements are given in Table 8 . Computer printouts that fully define the detailed nuclide contents of the two design-basis spent fuel definitions are available in Ref. 5. Tentative design values that summarize radiological characteristics of MEU-cycle equilibrium spent fuels are presented in Table 9. 
TABLE 6

SPENT FUEL ELEMENT DEFINITION FOR AVERAGE HTGR STANDARD MAKEUP ELEMENT - MEU CYCLE

(Core-Averaged Equilibrium Element at 180 Days After Discharge)

\section{Component}

$$
\begin{aligned}
& \text { Fissile particles }\left(\rho \simeq 2.64 \mathrm{~g} / \mathrm{cm}^{3}\right) \\
& \text { Outer PyC coating } \\
& \text { SiC coating }(1.85 \mathrm{~kg} \mathrm{Si}) \\
& \text { Inner PyC coating } \\
& \text { Buffer coating } \\
& \text { Kerne1 (UCO; } \left.\simeq 10.6 \mathrm{~g} / \mathrm{cm}^{3}\right) \\
& \text { Tota1 U (kernel) } \\
& \left(\begin{array}{c}
3.9 \% \mathrm{U}-235 \\
3.5 \% \mathrm{U}-236 \\
92.6 \% \mathrm{U}-238 \\
\mathrm{by} \text { mass }
\end{array} \mid\right.
\end{aligned}
$$

Total C (kernel)

Tota1 o (kerne1)

other fission and activation products

Fertile particles $\left(\rho \simeq 3.44 \mathrm{~g} / \mathrm{cm}^{3}\right)$

Outer PyC coating

Buffer coating

Kernel $\left(\mathrm{ThO}_{2} ; \rho \simeq 9.9 \mathrm{~g} / \mathrm{cm}^{3}\right.$ )

Total Th (kernel)

Total U (kernel)

$$
\left.\mid \begin{array}{cc}
<0.1 \% & \mathrm{U}-232 \\
83.0 \% & \mathrm{U}-233 \\
14.2 \% & \mathrm{U}-234 \\
2.5 \% & \mathrm{U}-235 \\
0.3 \% & \mathrm{U}-236 \\
\text { by mass }
\end{array}\right\}
$$

Total o (kernel

Other fission and activation products

Graphite block (includes plugs, dowels, matrix, and shim)

Boron

Total mass
Mass

(kg/fuel element)

10.38

2.35

2.64

1.24

1.22

2.93

1.85

0.18

0.24

0.66

7.28

2.25

0.87

4.16

3.22

0.11

0.72

0.11

97.52

0.002

115.18 
TABLE 7

SPENT FUEL ELEMENT DEFINITION FOR AVERAGE HTGR STANDARD U-233 RECYCLE ELEMENT - MEU CYCLE

(Core-Averaged Equilibrium Element

at 180 Days After Discharge)

Component

Fissile particle
Outer PyC coat
SiC coating (0
Inner PyC coat
Buffer coating
Kernel (WAR UCO
Total U (kerne
\[ \begin{array}{cc}<0.1 \% & \text { U-232 } \\ 20.2 \% & \text { U-233 } \\ 44.4 \% & \text { U- } 234 \\ 19.5 \% & \mathrm{U}-235 \\ 15.8 \% & \mathrm{U}-236 \\ \text { by mass }\end{array} \]

Total C (kerne1)

Total o (kernel)

other fission and activation products

Fertile particles $\left(\rho \simeq 3.44 \mathrm{~g} / \mathrm{cm}^{3}\right)$

Outer PyC coating

Buffer coating

Kernel $\left(\mathrm{ThO}_{2} ; \rho \simeq 9.9 \mathrm{~g} / \mathrm{cm}^{3}\right)$

Total Th (kernel)

Total U (kernel)

$\left\{\begin{array}{cc}<0.1 \% & \mathrm{U}-232 \\ 83.0 \% & \mathrm{U}-233 \\ 14.2 \% & \mathrm{U}-234 \\ 2.5 \% & \mathrm{U}-235 \\ 0.3 \% & \mathrm{U}-236 \\ \text { by mass }\end{array}\right\}$

Tota1 o (kernel)

other fission and activation products

Graphite block (includes plugs, dowels, matrix, and shim)

Boron

0.002

Tota1 mass
0.72

0.06

100.93

110.05
Mass

( $\mathrm{kg} /$ fuel element)

3.50

1.00

1.23

0.56

0.38

0.33

0.09

0.04

0.05

0.15

5.62

2.25

0.87

2.50

1.66

0.06 
TABLE 8

PLUTONIUM CONTENT IN SPENT MEU-CYCLE FUELS

(Core-Averaged Equilibrium Elements at 180 Days After Discharge)

\begin{tabular}{|c|c|c|c|c|}
\hline $\begin{array}{l}\text { Nuclide } \\
{[\text { as g/FE }(a)]}\end{array}$ & $\begin{array}{c}\text { MS } \\
\text { Fertile } \\
\text { Particle }\end{array}$ & $\begin{array}{c}\text { MS } \\
\text { Fissile } \\
\text { Particle }\end{array}$ & $\begin{array}{c}\text { 23RS } \\
\text { Fertile } \\
\text { Particle } \\
\end{array}$ & $\begin{array}{c}\text { 23RS } \\
\text { Fissile } \\
\text { Particle }\end{array}$ \\
\hline $\mathrm{Pu}-236$ & $2.3155-13$ & $2.1553-10$ & $1.1928-13$ & $6.6017-11$ \\
\hline $\mathrm{Pu}-238$ & $3.6559-03$ & $3.4391+00$ & $1.8834-03$ & $1.0342+00$ \\
\hline$P u-239$ & $2.5522-04$ & $1.8083+01$ & $1.3148-04$ & $9.6217-02$ \\
\hline $\mathrm{Pu}-240$ & $6.7209-05$ & $7.9738+00$ & $3.4623-05$ & $3.4617-02$ \\
\hline $\mathrm{Pu}-241$ & $4.1902-05$ & $9.8282+00$ & $2.1586-05$ & $1.1056-02$ \\
\hline $\mathrm{Pu}-242$ & $5.0703-05$ & $9.3230+00$ & $2.6120-05$ & $1.3224-02$ \\
\hline $\mathrm{Pu}-243$ & $2.8206-21$ & $5.1864-16$ & $1.4530-21$ & $7.3567-19$ \\
\hline$P u-244$ & $6.0911-09$ & $1.9281-04$ & $3.1378-09$ & $1.5086-07$ \\
\hline $\mathrm{Pu}-245$ & $1.3390-27$ & $4.2387-23$ & $6.8980-28$ & $3.3163-26$ \\
\hline $\mathrm{Pu}-246$ & $2.6809-21$ & $7.8383-17$ & $1.3811-21$ & $5.8905-20$ \\
\hline Plutonium & $4.0710-03$ & $4.8647+01$ & $2.0972-03$ & $1.2093+00$ \\
\hline
\end{tabular}

(a) $\mathrm{FE}=$ fuel element.

TABLE 9

RADIOLOGICAI CHARACTERISTICS OF EQUILIBRIUM SPENT FUELS

Component

23RS fertile particle

23RS fissile particle

MS fertile particle

MS fissile particle

23RS total

MS total
Watts/Fuel Element

$3.731 \times 10^{1}$

$4.945 \times 10^{1}$

$7.242 \times 10^{1}$

$2.081 \times 10^{2}$

$8.676 \times 10^{1}$

$2.805 \times 10^{2}$
Curies/Fuel Element

$9.962 \times 10^{3}$

$1.197 \times 10^{4}$

$1.934 \times 10^{4}$

$4.737 \times 10^{4}$

$2.197 \times 10^{4}$

$6.674 \times 10^{4}$ 
In addition to the design-basis spent fuels, the HRRF reprocessing plant must be capable of handling a variety of other fuel compositions. Examples include (1) low-irradiation fuel elements returned from a reactor, (2) unirradiated fuel elements that are rejected in the recycle fuel refabrication plant, (3) spent fuel elements from the first reload segment, and (4) spent special buffer zone elements with specialized fuel loadings. A number of fuel management variables may affect initial fuel loadings and, therefore, spent fuel compositions. Significant initial fuel loading variables include (1) the use of fuel rod blends to achieve desired core loadings, typically 15 or more blends per reload segment, and (2) variations within allowable ranges for both makeup and recycle fuel loading specifications.

Average spent fuel element definitions have been used as the bases for calculating the reprocessing throughput and material balances in this report. However, more reactive and possibly limiting fuel element compositions, e.g., unirradiated fuel, will be factored into later HRRF reprocessing equipment and systems design and layout studies.

\subsection{FLOWSHEET UPDATE FOR MEU-CYCLE REPROCESSTNG}

The reprocessing flowsheet scheme for the MEU fuel recycle base case is described in Section 2.3. The HRRF reprocessing flowsheets, revised for processing of spent MEU-cycle fuels rather than HEU-cycle fuels, are contained in Appendix A.

The reprocessing flowsheets for MEU-cycle fuel differ from those for HEU-cycle fuel in only a few major respects. Significant flowsheet effects brought about by a change from HEU-cycle reprocessing to MEU-cycle base-case reprocessing can be briefly summarized as follows:

1. Initial and makeup ( $I, M)$ fuel element fissile particles are separated from fertile particles by pneumatic classification. Subsequent waste system treatment of the separated fissile particles involves Immobilization in an inert matrix (e.g., 
vitrification in a glass matrix) and packaging for shipment to a federal waste repository.

In the HEU flowsheet, the (I,M) fissile particles are processed through dissolution and Purex solvent extraction for recovery of residual U-235 fuel values. However, HEU fissile particles from spent $25 \mathrm{R}$ fuel elements, which contain recovered residual U-235 from a prior irradiation cycle, are immobilized for disposal in a manner identical to that for makeup MEU fissile particles.

2. U-233 recycle fuel (23R) fissile particles are processed through dissolution and combined with fertile solution product for Acid Thorex solvent extraction processing to recover both bred and residual U-233 fuel values.

3. Purex solvent extraction is not needed for the MEU fuel recycle base case, since U-235 residual fuel values are not recovered, nor is plutonlum bred in the fissile particle separated from the residual $\mathrm{U}-235$ and fission products.

4. The MEU-cycle reprocessing flowsheet makes no provision for processing of spent Fort St. Vrain/MEU fuel nor for spent U-235 recycle (25RS) fuel. Both of these spent fuel types are handled in the HEU reprocessing flowsheet.

In MEU-cycle reprocessing, control of fuel particle breakage within specified limits and limitation of fissile-fertile crossover are perhaps even more important factors than in the HEU cycle. For example, breakage of fissile particles prior to or during the primary burning step may result in carryover of denatured spent uranium into the fertile stream; contamination of fertile-bred $U-233$ with $U-236$ and $U-238$ is to be minimized. The flowsheet update indicates differential leaching of the fertile stream as an option for mitigating this effect of fissile-fertile crossover. 
A number of miscellaneous revisions were made in the reprocessing system flowsheets, reflecting the results of recent development and engineering studies. These changes, applicable to both MEU- and HEU-cycle flowsheets, include (1) the use of a $\mathrm{CO}_{2}$ /nitrogen oxide sparge for fertile particle dissolution to promote iodine release to the off-gas system, (2) tentative changes in the sequence of burner off-gas treatment, (3) update of the Krypton Adsorption in Liquid Carbon Dioxide (KALC) off-gas processing flowsheet, (4) addition of krypton adsorption treatment for the gas stream released from $\mathrm{C}-14$ fixation, and (5) inclusion of macroreticular resin treatment for a final product sidestream in the second-cycle solvent cleanup system. The resin-treated solvent is used in the second-cycle thorium solvent extraction flowsheet.

\subsection{MATERIAL BALANCE UPDATE FOR MEU-CYCLE REPROCESSING}

The design assumptions and proposed operating mode for HRRF reprocessing are basic factors influencing the material balance for the reprocessing system flowsheets. Both of these factors are described in Section 3. The HRRF reprocessing material balance data tables, revised for processing of spent MEU-cycle fuels rather than HEU-cycle fuels, are contained in Appendix B.

It should be noted that material balances were calculated for a throughput rate of 10,000 spent fuel elements per year, corresponding to the processing capacity of each of two parallel HRRF head-end process systems. Using a processing basis of 10,000 fuel elements per year for the MEU-cycle material balance tables has the further advantage of providing a direct comparison to prior published HEU material balance data; the HEU materials data were prepared in 1977 for the Phase I HTGR Recycle Demonstration Facility concept. This activity is described in Ref. 6.

The material balance data contained in Appendix $B$ are based on average fuel element definitions in a recycle plant operating at equilibrium, i.e., several years after startup. The material balance for 
PF-250-1, "Head-End Fuel Element Crush-Primary Burn-Classify," and PF-250-2, "Head-End Fertile Fraction Leaching," is based on 43 elements per day throughput of spent MEU makeup elements, which are defined in Table 6. This reprocessing feed was selected because it is representative of high throughput requirements for $P F-250-1$ and $P F-250-2$. The material balance for PF-250-3, "Head-End Fissile Particle Crush-Secondary Burn-Leach," is based on 43 elements per day throughput of spent U-233 recycle elements. This processing feed, defined in Table 7, had to be selected because only U-233 recycle fissile particles are reprocessed in the MEU fuel recycle base case.

Clarified dissolver solutions containing recovered residual U-233 from fissile particles, and solutions containing recovered bred U-233 from fertile particles, may be combined for accountability measurement if they originate in the same customer lot. Therefore, the combined U-233 dissolver solution was taken as the computation basis for the Thorex solvent extraction flowsheet material balances.

As shown in Section 4.2, the technology for reprocessing of spent MEU fuel does not vary significantly from that required for HEU fuel. Consequently, the flowsheet revisions for MEU-cycle reprocessing are relatively minor. However, the impact of the MEU cycle is felt more strongly in the quantification of materials flow through the reprocessing plant. Therefore, the MEU fuel cycle is expected to affect the equipment requirements and configuration for the HRRF reprocessing plant.

Differences in materials flow through reprocessing become apparent when comparing the MEU-cycle material balance data contained in Appendix $B$ to HEU-cycle data previously reported in Ref. 6. Spent fuel definitions for makeup elements in the MEU and HEU cycles are summarized in Table 10 . These spent fuel definitions highlight the difference in feed materials for MEU- and HEU-cycle reprocessing. Table 11 summarizes the spent fuel definitions for recycle fuels which will be reprocessed in MEU or HEU cycles. As shown in the table, only one type of spent recycle fuel (23R) 
TABLE 10

SPENT FUEL DEFINITIONS FOR MAKEUP ELEMENTS

MEU Cycle HEU Cycle

\begin{tabular}{|c|c|c|}
\hline Type & Dense UCO or $\mathrm{UC}_{2}$ & WAR-UC ${ }_{x}{ }_{y}$ \\
\hline Kilograms/fuel element & 10.38 & 6.45 \\
\hline Coating & TRISO & TRISO \\
\hline \multicolumn{3}{|l|}{ Fertile particles } \\
\hline Type & Dense $\mathrm{ThO}_{2}$ & Dense $\mathrm{ThO}_{2}$ \\
\hline Kilograms/fuel element & 7.28 & 15.86 \\
\hline Coating & BISO & BISO \\
\hline \multicolumn{3}{|c|}{ Heavy metal content in fissile particles } \\
\hline Uranium, kg & 1.85 & 0.22 \\
\hline Fissile U, wt \% & 3.9 & 29.5 \\
\hline Non-fissile U, wt \% & 96.1 & 70.5 \\
\hline Plutonium, kg & 0.05 & 0.01 \\
\hline $\mathrm{Pu}-239$ and $\mathrm{Pu}-241$, wt $\%$ & 57 & 21 \\
\hline Other $\mathrm{Pu}$ isotopes, wt \% & 43 & 79 \\
\hline $\mathrm{Pu}-238$, wt \% & 7 & 66 \\
\hline \multicolumn{3}{|c|}{ Heavy metal content in fertile particles } \\
\hline Thorium, $\mathrm{kg}$ & 3.22 & 7.94 \\
\hline Uranium, $\mathrm{kg}$ & 0.11 & 0.26 \\
\hline $\mathrm{U}-233$, wt \% & 83 & 80 \\
\hline U-235, wt \% & $<3$ & $<4$ \\
\hline
\end{tabular}


TABLE 11

SPENT FUEL DEFINITIONS FOR RECYCLE FUELS

\begin{tabular}{|c|c|c|c|}
\hline \multirow{3}{*}{ Number of fuel elements/reload segment ${ }^{(a)}$} & \multicolumn{2}{|c|}{ HEU Cycle } & \multirow{2}{*}{$\frac{\text { MEU Cycle }}{23 R}$} \\
\hline & $\underline{23 R}$ & $25 \mathrm{R}$ & \\
\hline & $431(45 \%)$ & $29(3 \%)$ & $450(34 \%)$ \\
\hline $\begin{array}{l}\text { Fissile particle type } \\
\text { Coating }\end{array}$ & $\begin{array}{l}\text { WAR-UC } \mathrm{x}^{\mathrm{O}} \mathrm{y} \\
\text { TRISO }\end{array}$ & $\begin{array}{l}\text { WAR-UC } \mathrm{O} y \\
\text { TRISO }\end{array}$ & $\begin{array}{l}\text { WAR-UC } x \mathrm{O} \\
\text { TRISO }\end{array}$ \\
\hline Kerne1 density, $\mathrm{g} / \mathrm{cm}^{3}$ & 3.3 & 3.3 & 3.3 \\
\hline Fertile particle type & $\mathrm{ThO}_{2}$ & $\mathrm{ThO}_{2}$ & $\mathrm{ThO}_{2}$ \\
\hline Coating & BISO & BISO & BISO \\
\hline Kerne1 density, $\mathrm{g} / \mathrm{cm}^{3}$ & 9.9 & 9.9 & 9.9 \\
\hline \multicolumn{4}{|l|}{ Heavy metal content in fissile particles } \\
\hline Uranium, kg & 0.16 & 1.40 & 0.09 \\
\hline Fissile U, wt \% & 39.9 & 3.64 & 39.7 \\
\hline Nonfissile $U$, wt \% & 60.1 & 96.4 & 60.3 \\
\hline Plutonium, $\mathrm{kg}$ & 0.001 & 0.08 & 0.0012 \\
\hline Pu-239 and Pu-241, wt \% & 10.8 & 20.8 & 10.5 \\
\hline Other $\mathrm{Pu}$ isotopes, wt \% & 89.2 & 79.2 & 89.5 \\
\hline $\mathrm{Pu}-238$, wt $\%$ & 85.2 & 65.8 & 85.1 \\
\hline \multicolumn{4}{|l|}{ Heavy metal content in fertile particles } \\
\hline Thorium, kg & 7.94 & 7.94 & 1.66 \\
\hline Uranium, $\mathrm{kg}$ & 0.26 & 0.26 & 0.06 \\
\hline Fissile $\mathrm{U}$, wt $\%$ & 83.4 & 83.4 & 85.5 \\
\hline Nonfissile U, wt \% & 16.6 & 16.6 & 14.5 \\
\hline
\end{tabular}


needs to be reprocessed in the base-case MEU cycle. In the HEU cycle, both $23 R(U-233)$ and $25 R(U-235)$ spent recycle fuels are to be reprocessed.

Pertinent characteristics of fresh fuel elements for the $20 \%$ enriched MEU cycle and for the $93 \%$ enriched HEU cycle are summarized and compared in Table 12. 
TABLE 12

EQUILIBRIUM MAKEUP FUEL ELEMENT SUMMARY

\begin{tabular}{|c|c|c|}
\hline & MEU Cycle & HEU Cycle \\
\hline C/Th ratio & $400-850$ & 240 \\
\hline \multicolumn{3}{|l|}{ Fissile particles (TRISO coated) } \\
\hline Type & Dense UCO or $\mathrm{UC}_{2}$ & WAR-UC $\mathrm{x}_{\mathrm{y}} \mathrm{O}$ \\
\hline Kerne1 density, $\mathrm{g} / \mathrm{cm}^{3}$ & 10.6 (for UCO) & 3.3 \\
\hline Kernel diameter, $\mu \mathrm{m}$ & 350 & 305 \\
\hline Particle diameter, $\mu \mathrm{m}$ & 790 & 650 \\
\hline Particle density, $\mathrm{g} / \mathrm{cm}^{3}$ & 2.64 & 2.2 \\
\hline \multicolumn{3}{|l|}{ Fertile particles (BISO coated) } \\
\hline Type & Dense $\mathrm{ThO}_{2}$ & Dense $\mathrm{ThO}_{2}$ \\
\hline Kernel density, $\mathrm{g} / \mathrm{cm}^{3}$ & $>9.5$ & $>9.5$ \\
\hline Kerne1 diameter, $\mu \mathrm{m}$ & 500 & 500 \\
\hline Particle diameter, $\mu \mathrm{m}$ & 820 & 820 \\
\hline Particle density, $\mathrm{g} / \mathrm{cm}^{3}$ & 3.44 & 3.44 \\
\hline Uranium loading/fuel element, $\mathrm{kg}$ & 3.55 & 0.84 \\
\hline $\mathrm{U}-238$, wt \% & 80.2 & 5.9 \\
\hline$U-235$, wt \% & 19.8 & 93.1 \\
\hline Thorium loading/fuel element, $\mathrm{kg}$ & 5.16 & 8.55 \\
\hline Fuel rod diameter, $\mathrm{cm}$ & 1.40 & 1.60 \\
\hline $\begin{array}{l}\text { Makeup fuel elements/reload } \\
\text { segment }(a)\end{array}$ & $872(66 \%)$ & $500(52 \%)$ \\
\hline
\end{tabular}
(a) $3360 \mathrm{MW}(\mathrm{t})$ HTGR 


\section{SUMMARY AND CONCLUSIONS}

The flowsheets for reprocessing of spent HTGR fuel elements have been revised for the MEU recycle base case, and corresponding materials balance data for HRRF reprocessing of spent MEU and recycle fuels have been calculated.

Compared to HEU fuel recycle, it was concluded that the reprocessing of spent MEU and recycle fuel elements generally uses the reprocessing technology developed for the HEU cycle. Flowsheet revisions for MEU reprocessing include:

Immobilization and packaging of $I, M$ fissile particles, following separation from burned-back fertile particles.

Combination of $23 \mathrm{R}$ fissile particle product solution with fertile product solution for subsequent Thorex solvent extraction processing.

Purex solvent extraction is not needed for the MEU fuel recycle base case, since residual U-235 fuel values and bred Pu are not recovered. Nevertheless, the HRRF reprocessing plant design is expected to include a Purex capability to permit recovery of low-burnup $20 \%$-enriched U-235 fissile values.

Reprocessing of spent MEU fuel was found to have a significant effect on materials mass flow, relative to HEU reprocessing. Therefore, the MEU fuel cycle is expected to affect the present HEU process equipment requirements and, consequently, the configuration for the HRRF reprocessing plant. 


\section{ACKNOWLEDGMENTS}

The author gratefully acknowledges the valuable assistance of the technical staff of the Head-End Operations and Separation Development Branches in the preparation of material balance data. 


\section{REFERENCES}

1. "National Program Plan for HTGR Fuel Recycle Development," Oak Ridge National Laboratory Report GCR-76/19, Rev. 3, October 1977.

2. Merri11, M. H., General Atomic Company, "Definition of a Reference MEU/Th Cycle with Non-Denatured U-233 Recycle in the LHTGR," December 27, 1977, private communication.

3. Turner, R. F., "Minutes of FRB Meeting 1977-9," December 6, 1977, General Atomic Company unpublished data.

4. Lotts, A. L. (ORNL), letter to J. W. Allen (GA), "HTGR Fue1 Recycle Development Program: Reference MEU Fuel Cycle," January 12, 1978.

5. Zane, G., D. L. Georghiou, and C. J. Everline, "LHTGR MEU Spent Fuel Element Definitions and Block Flows," DOE Report GA-A14980, General Atomic Company (to be published).

6. Holder, N., and L. Abraham, "Reprocessing Yields and Material Throughput - HTGR Recycle Demonstration Facility," ERDA Report GA-A14320, Genera1 Atomic Company, August 1977. 
-

- 
APPENDIX A

HRRF REPROCESSING FLOWSHEETS FOR MEU-CYCLE FUELS 


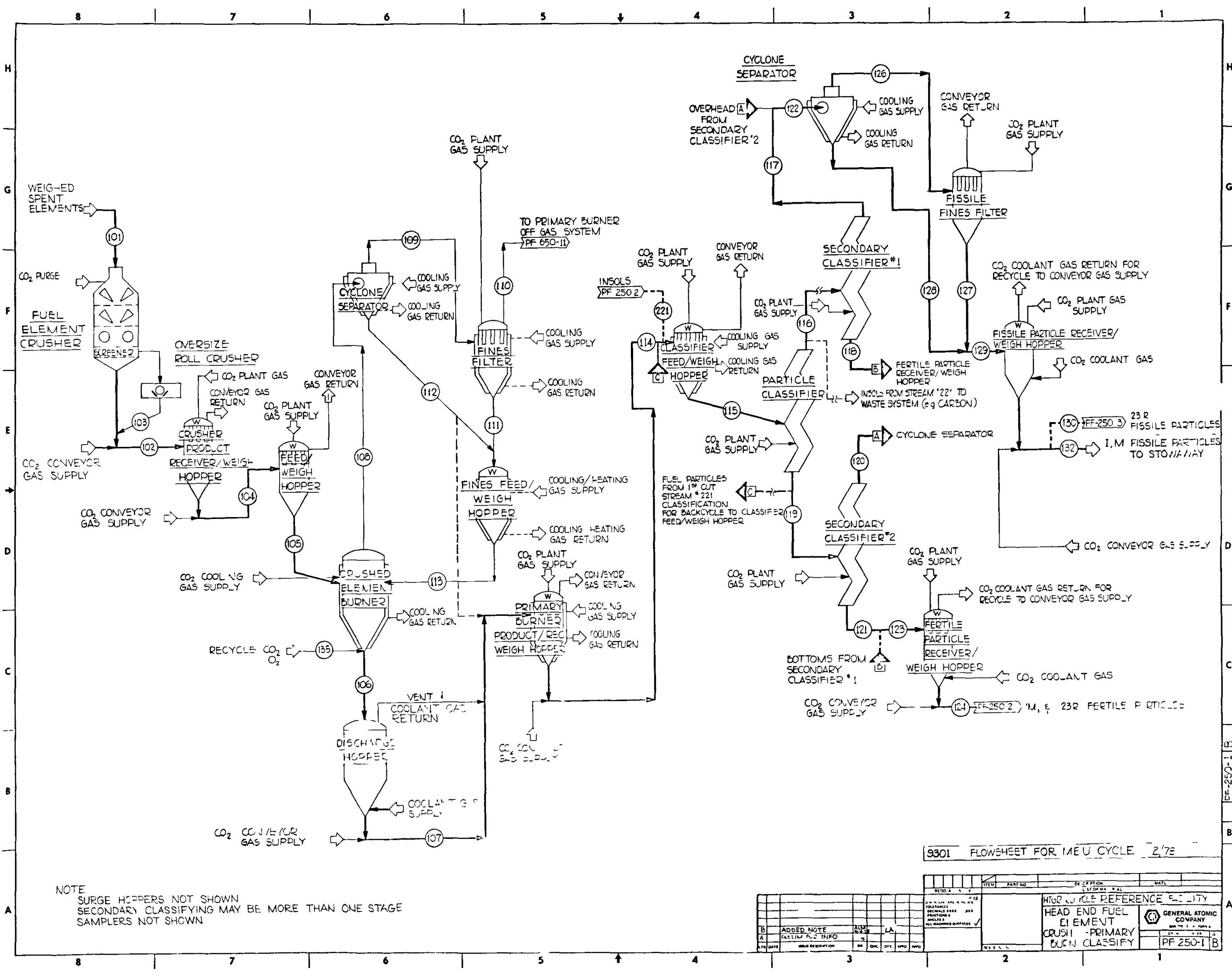




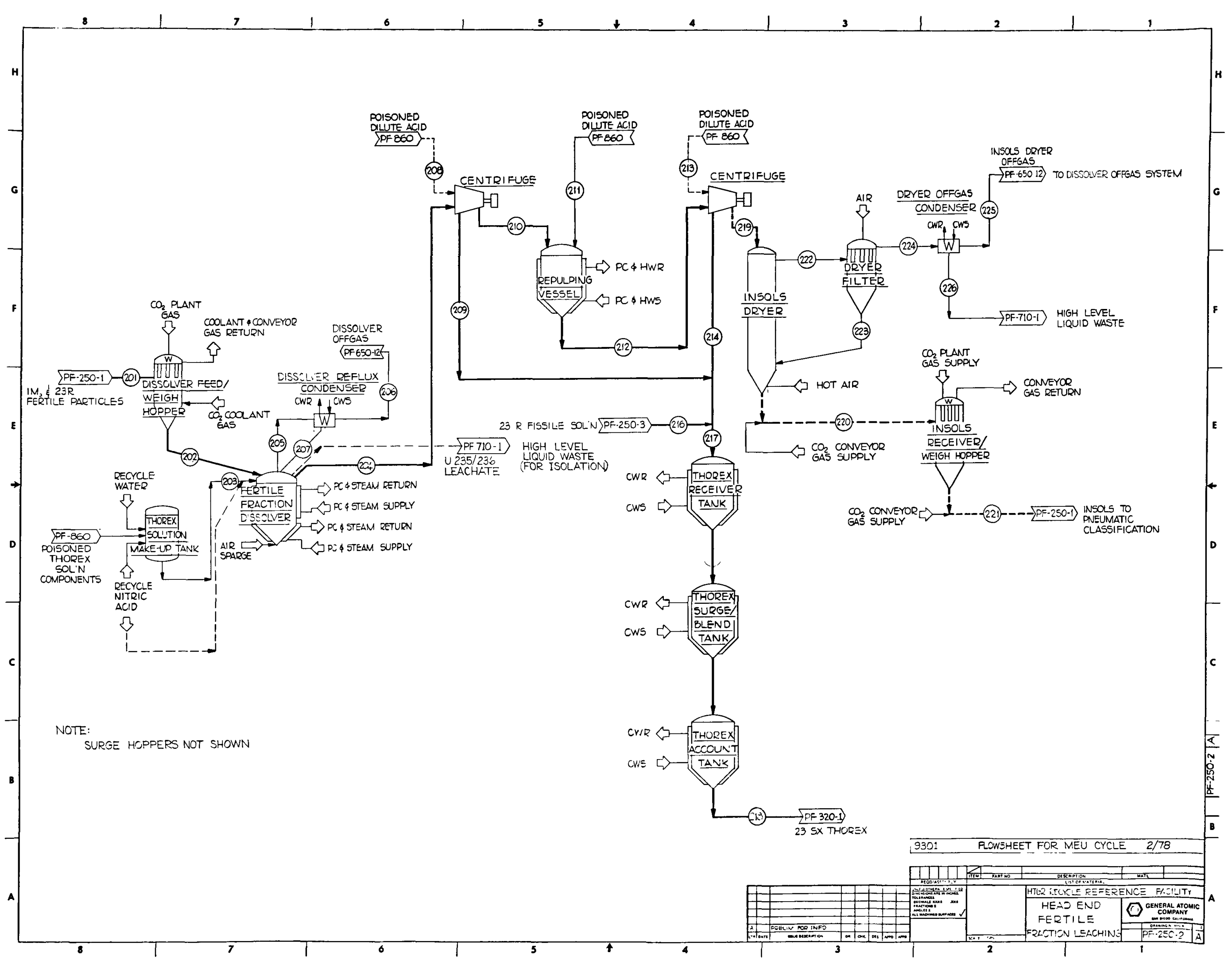




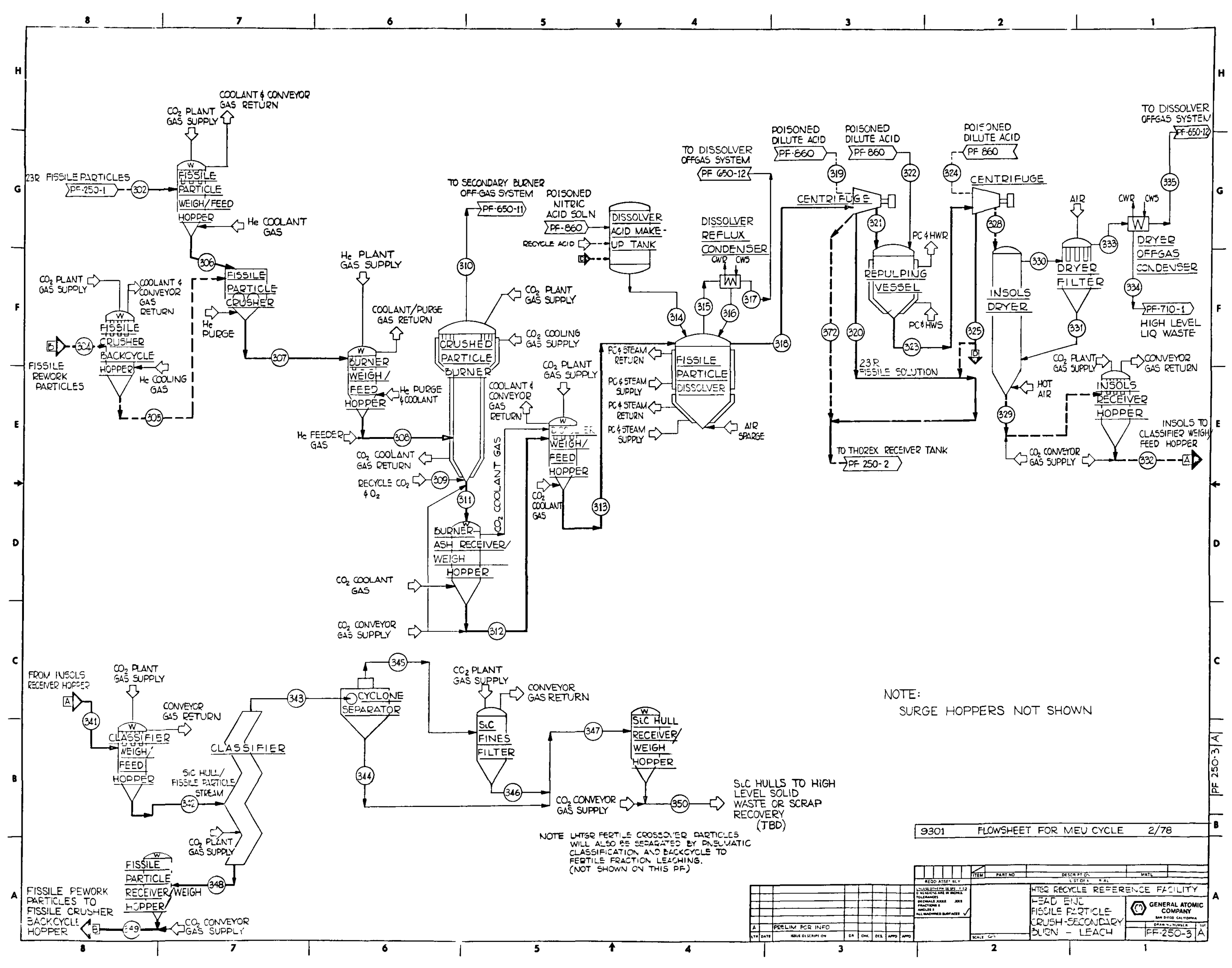




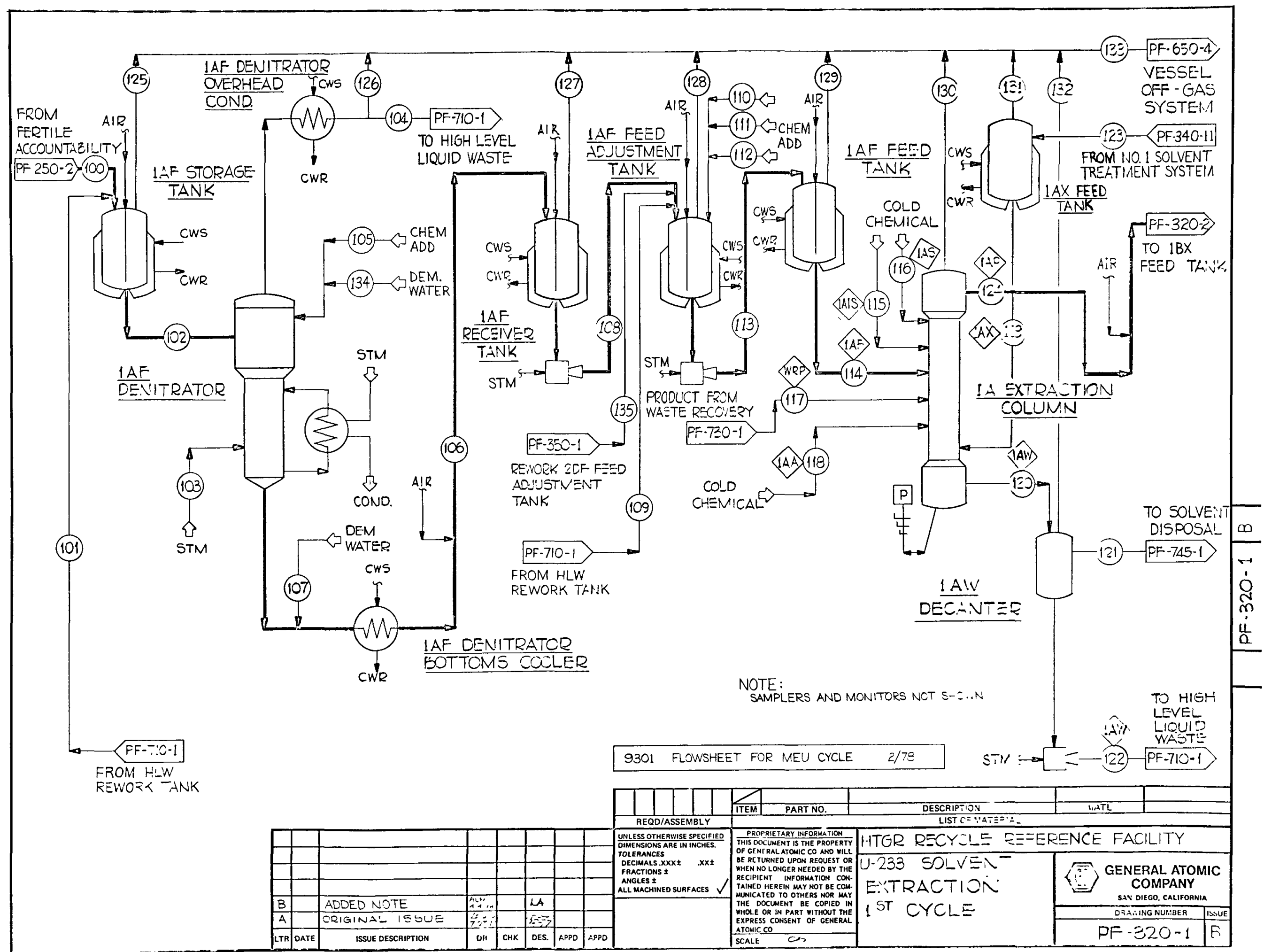




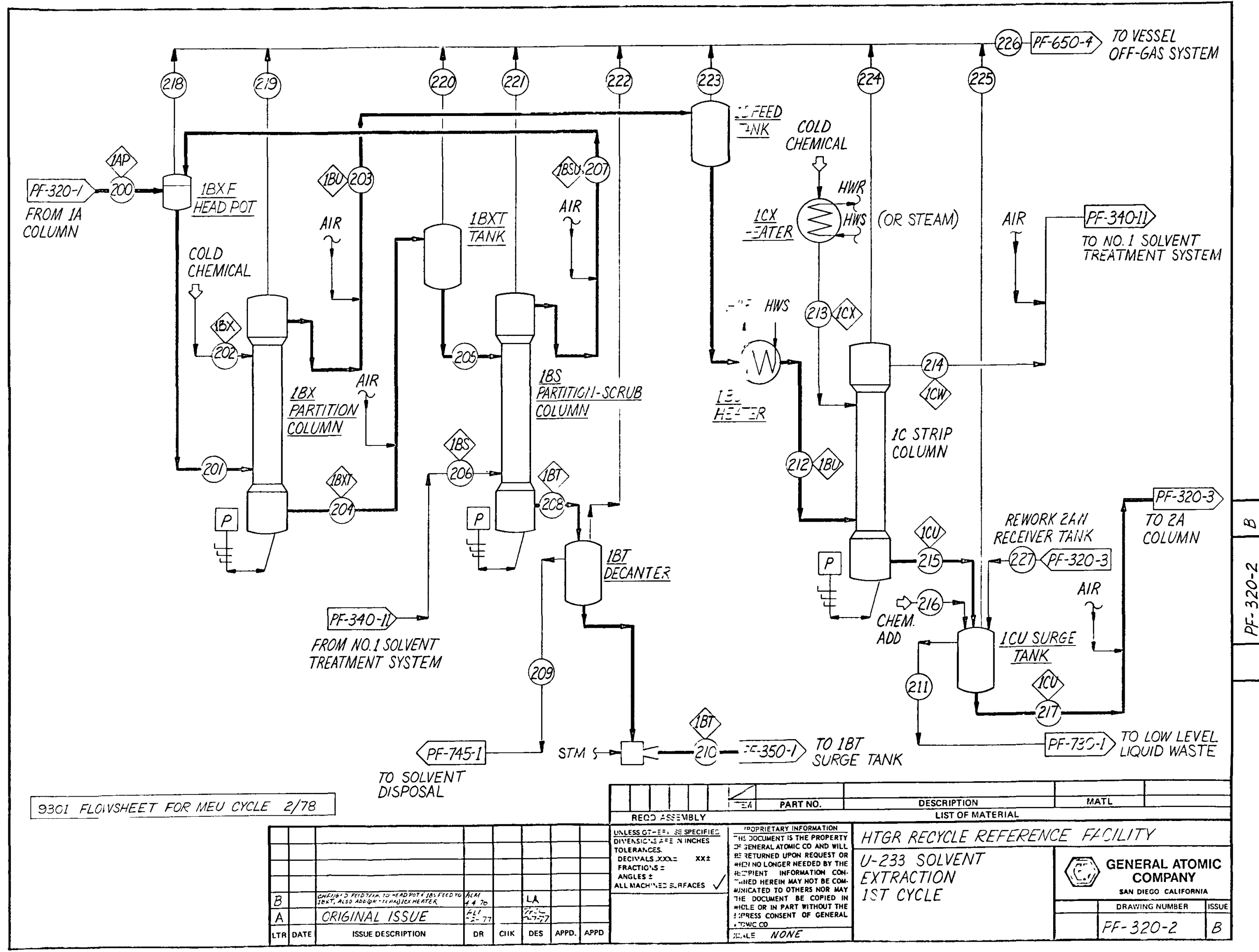




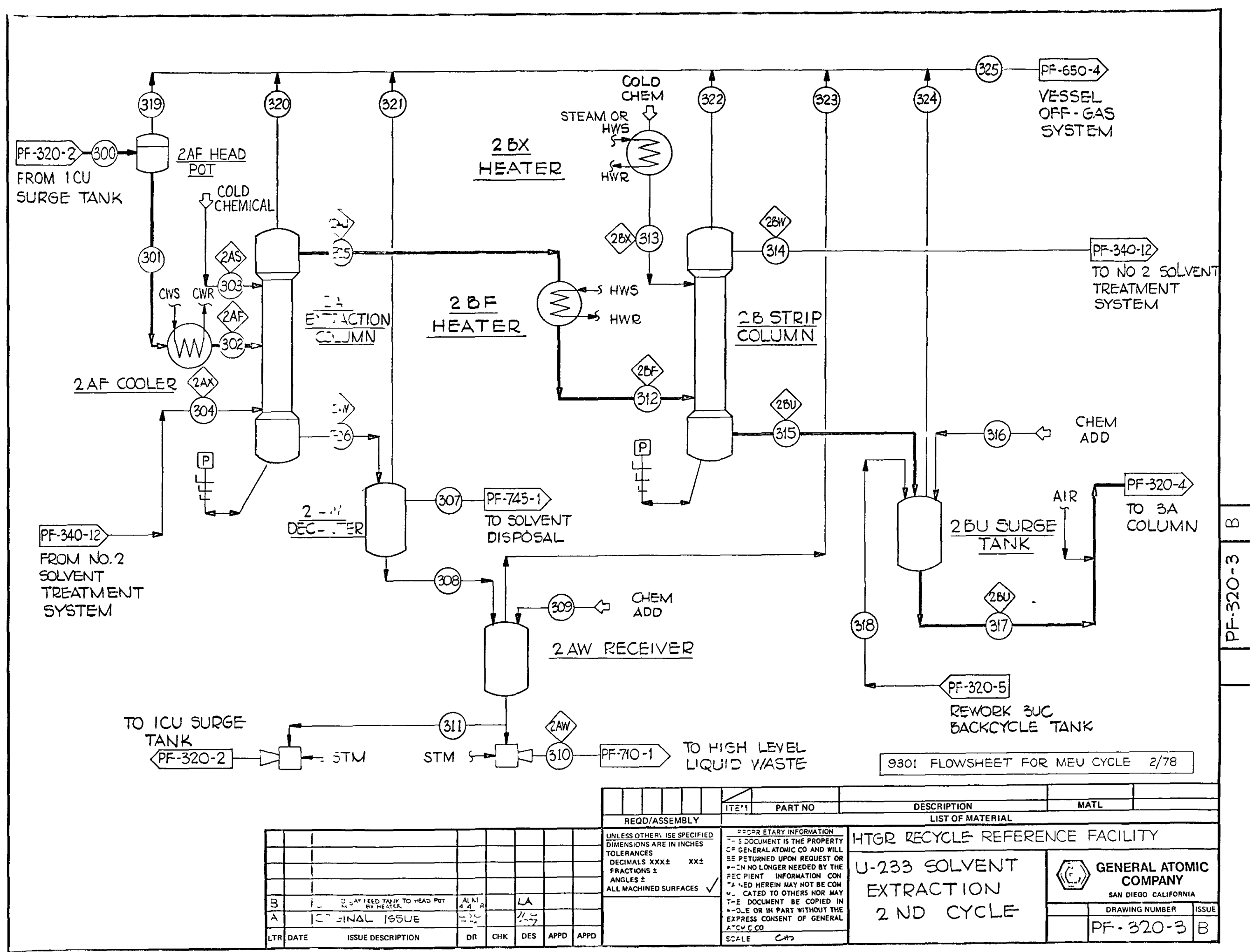




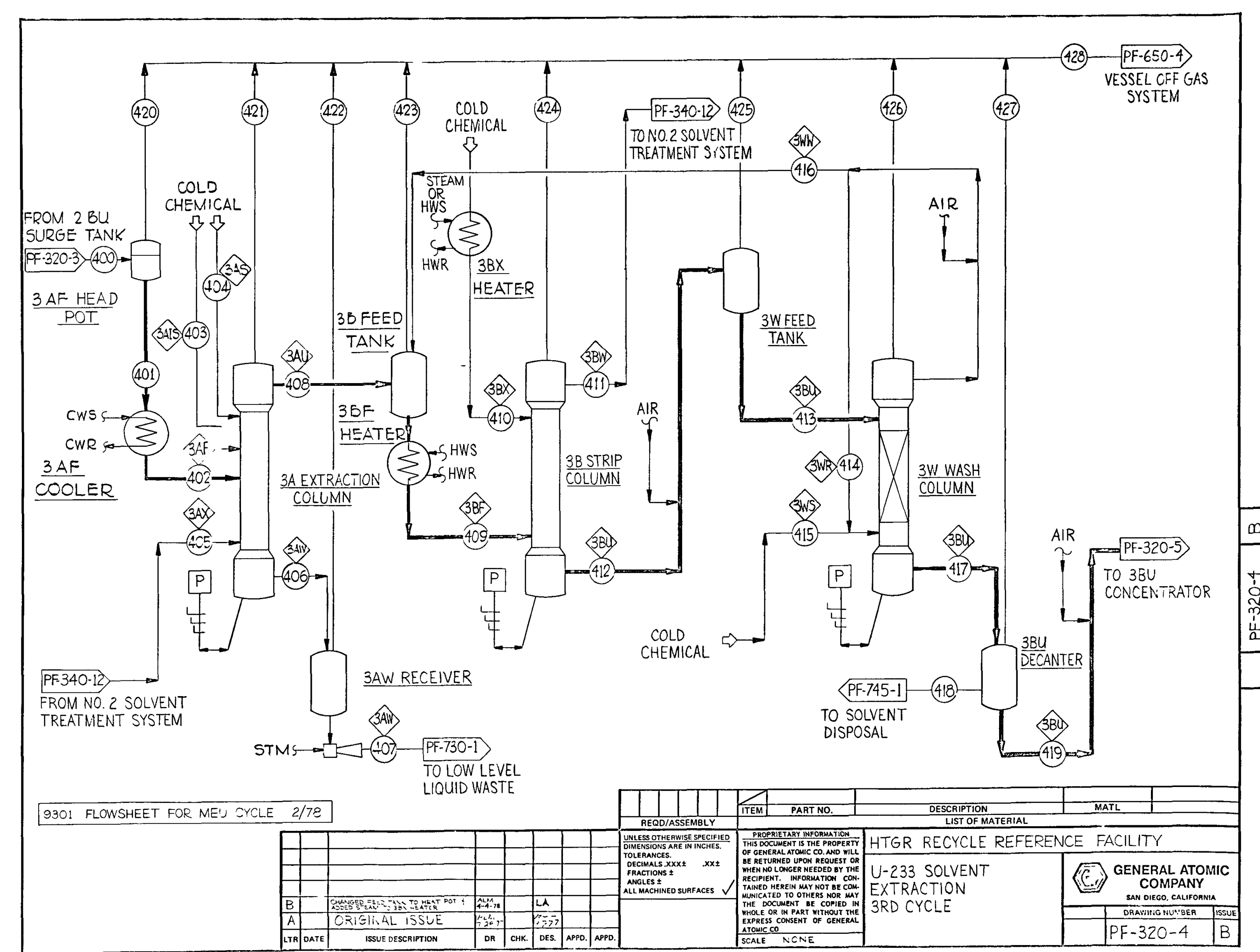




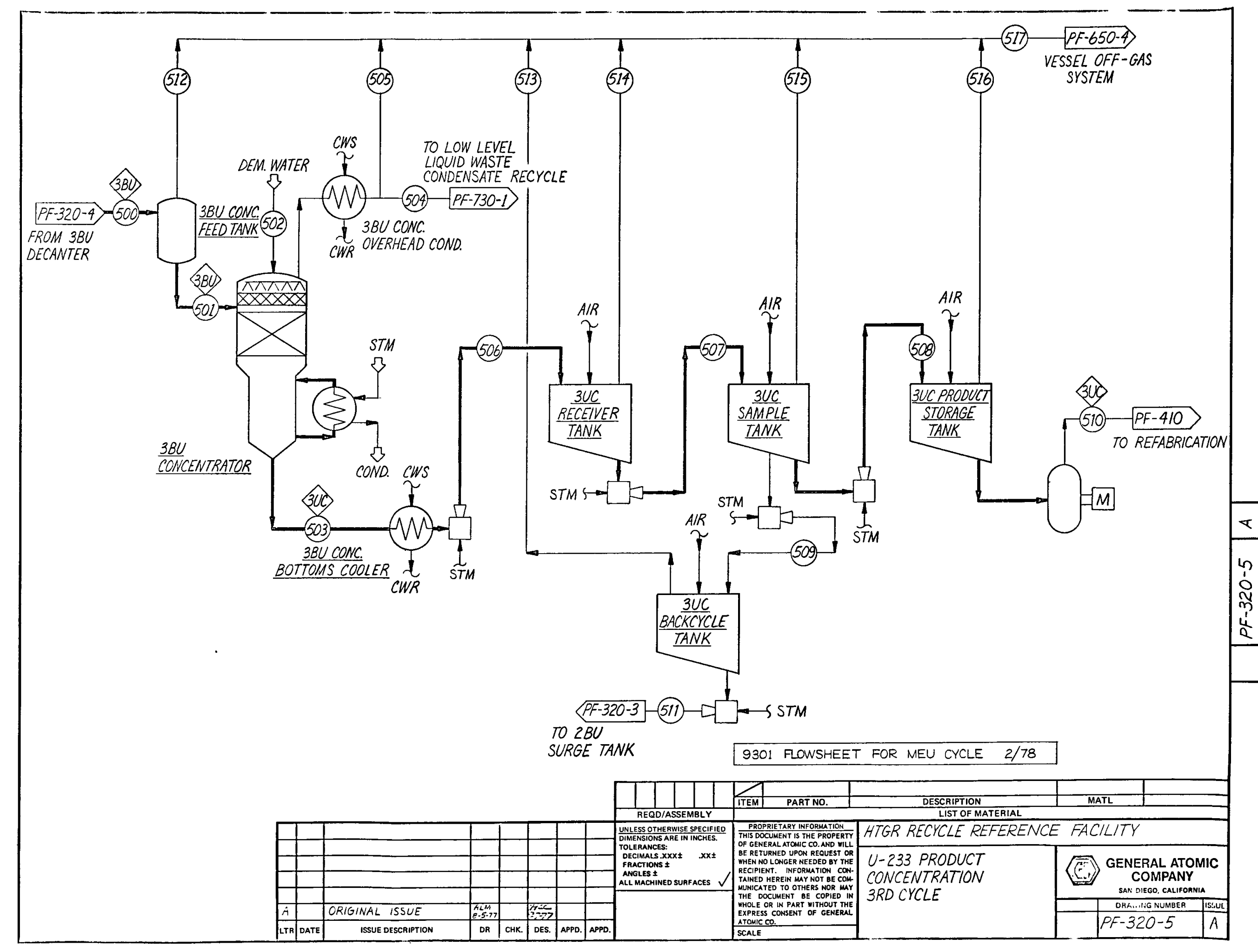




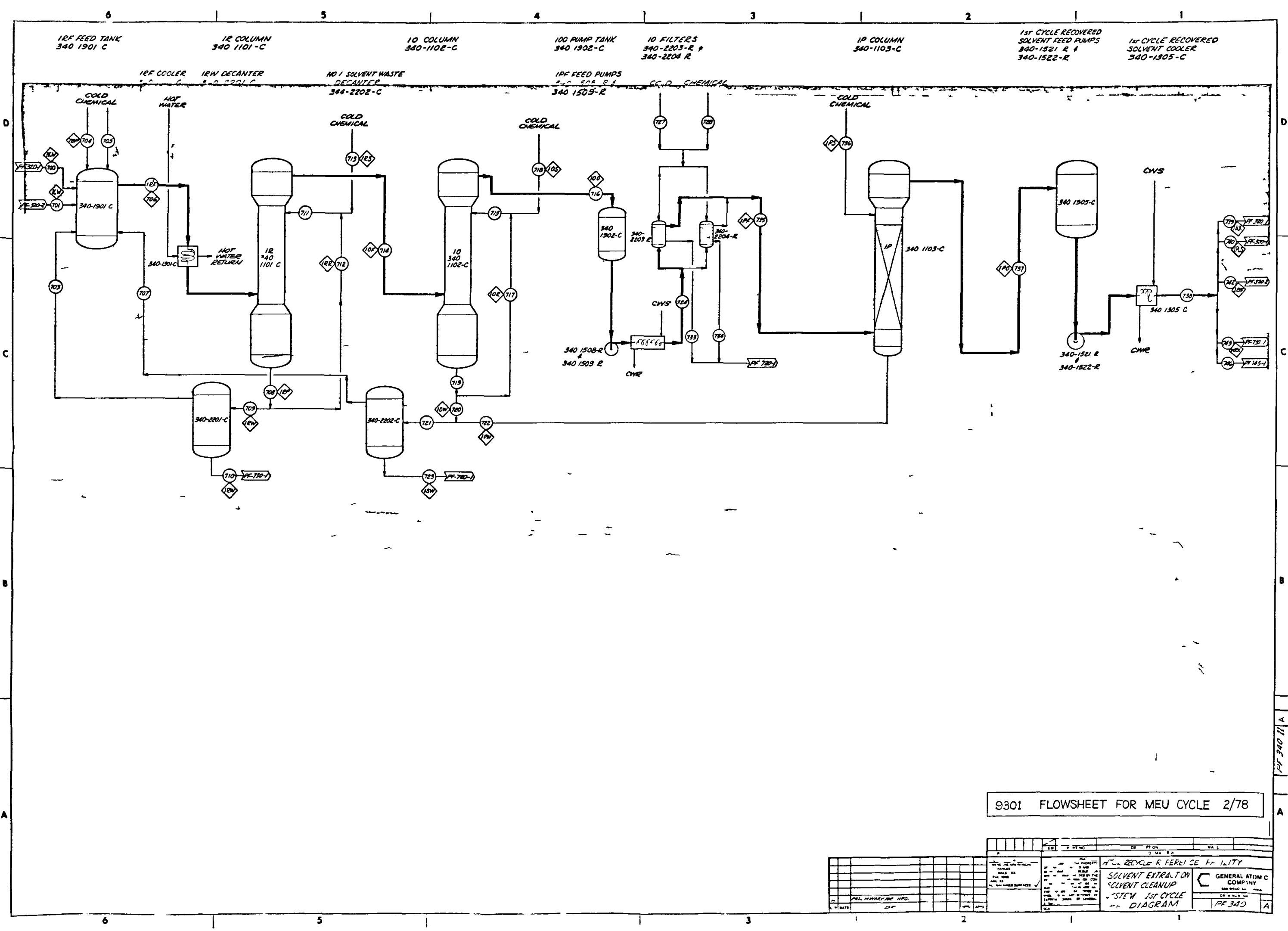




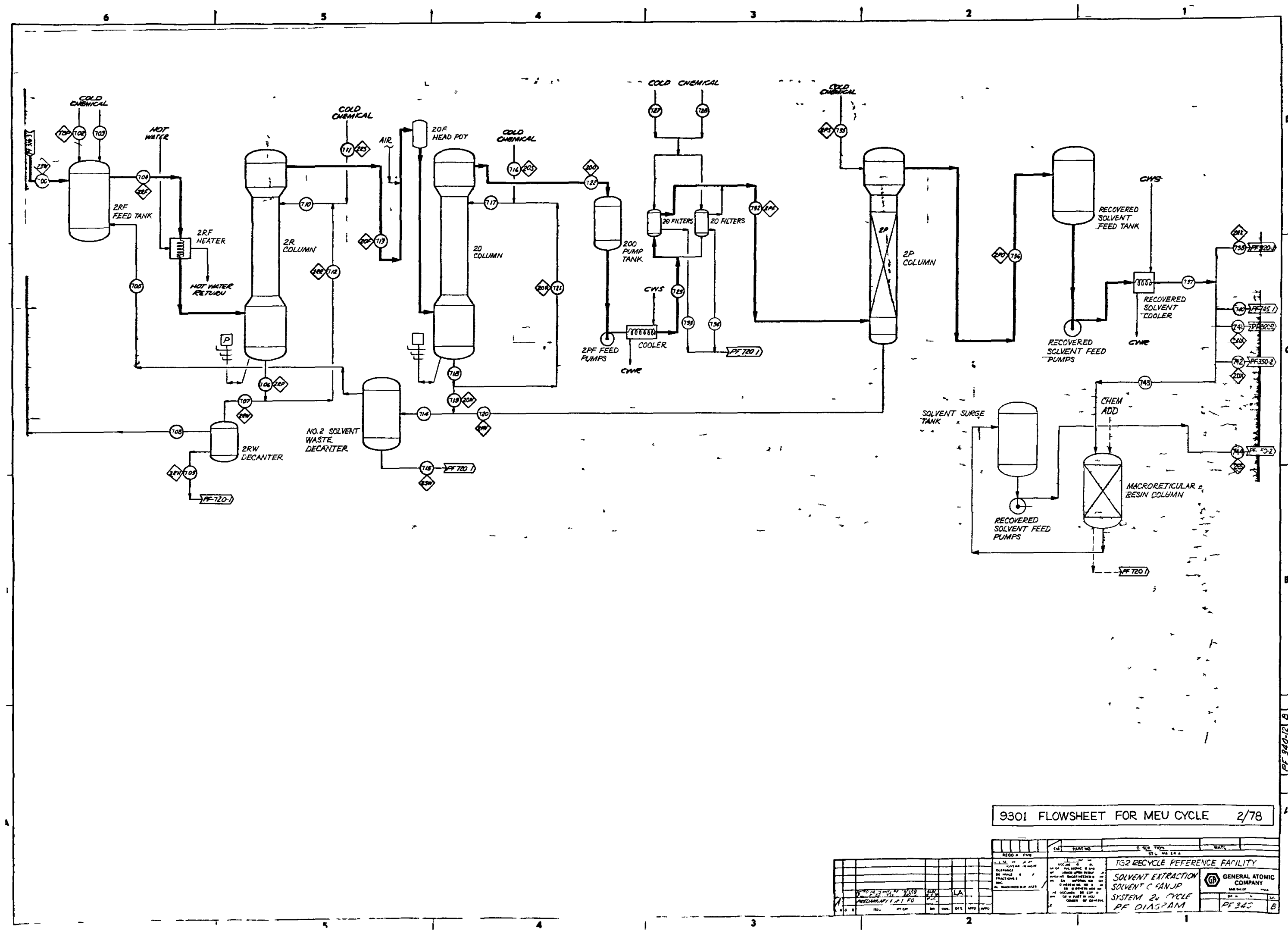




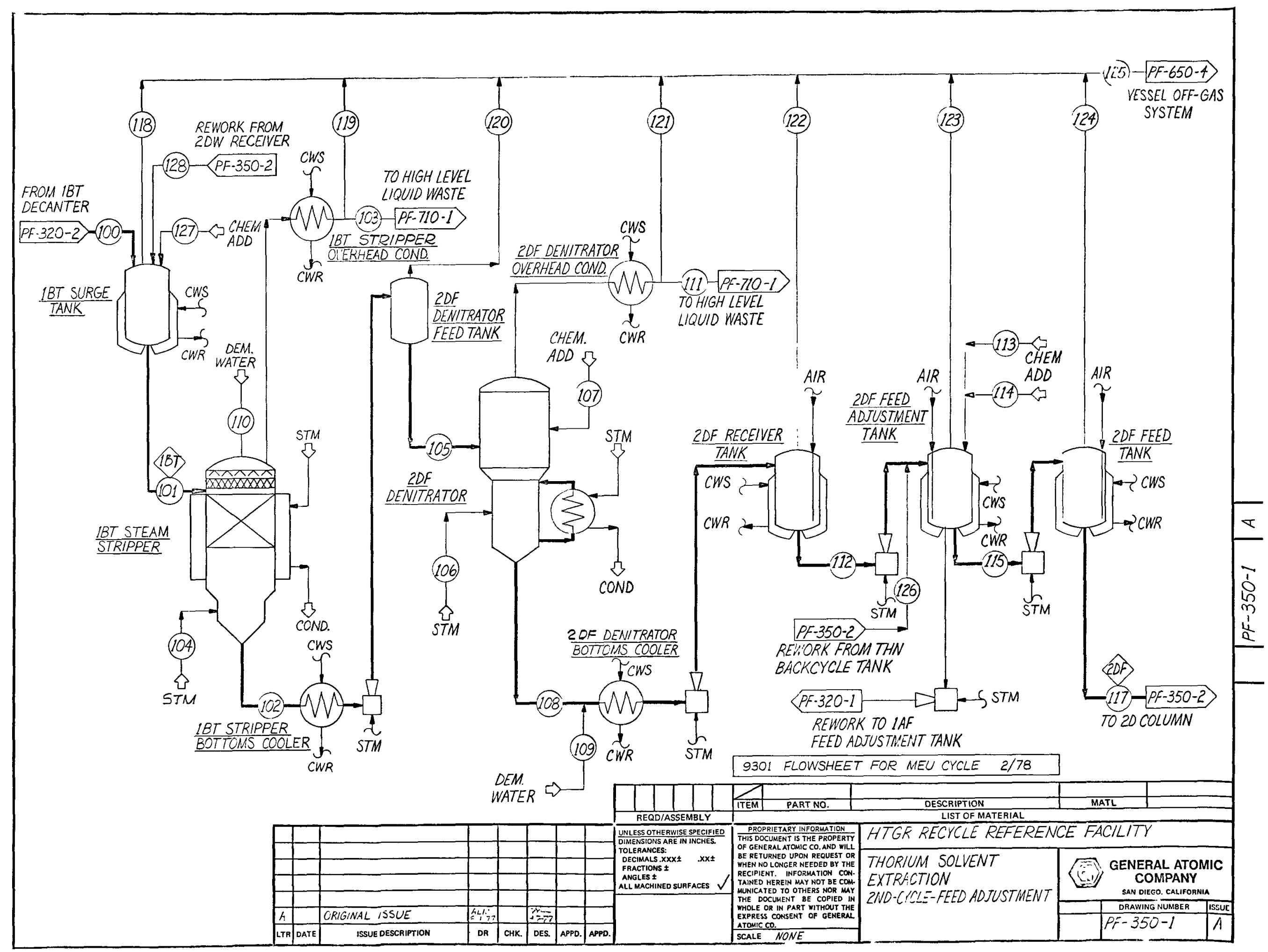




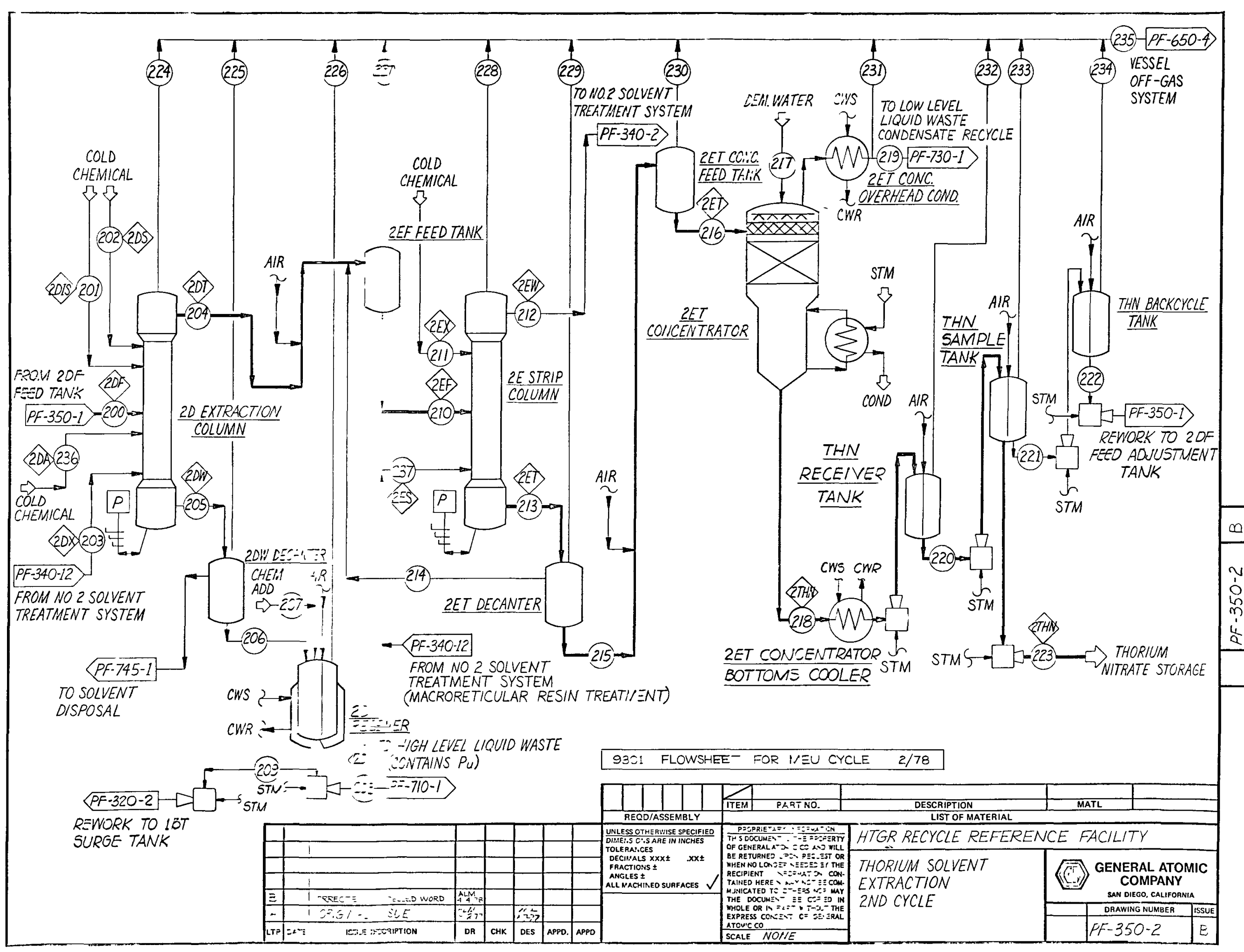




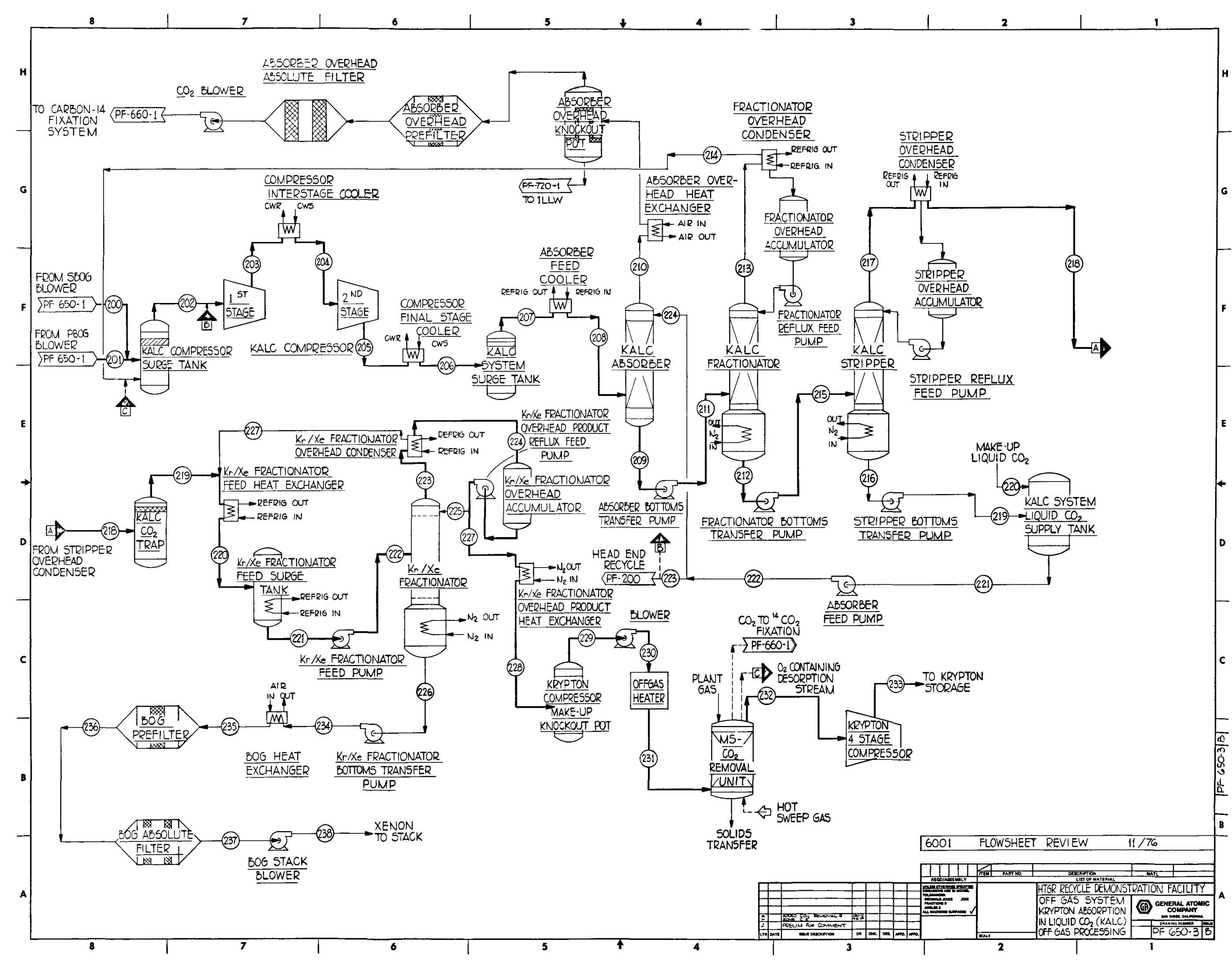




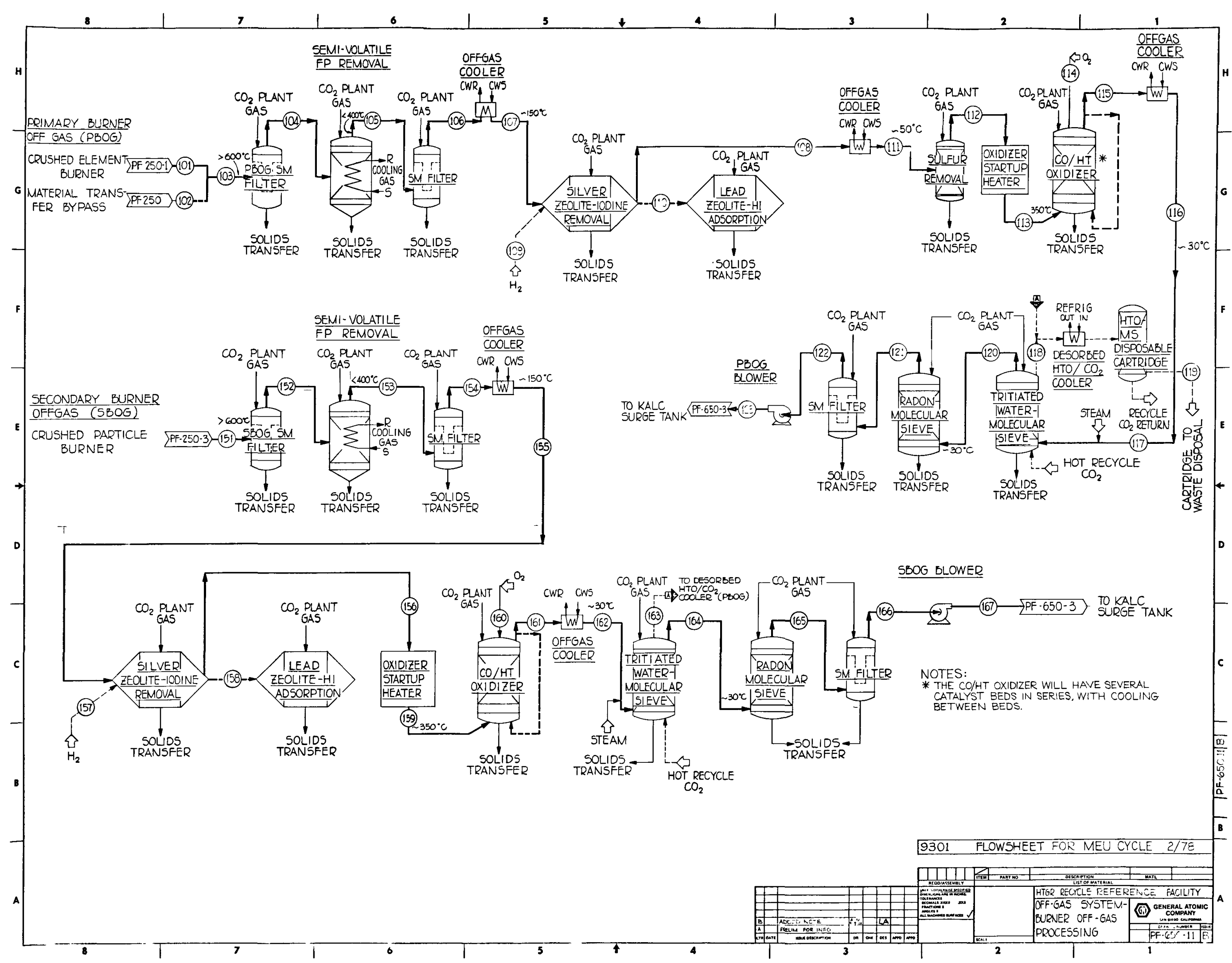




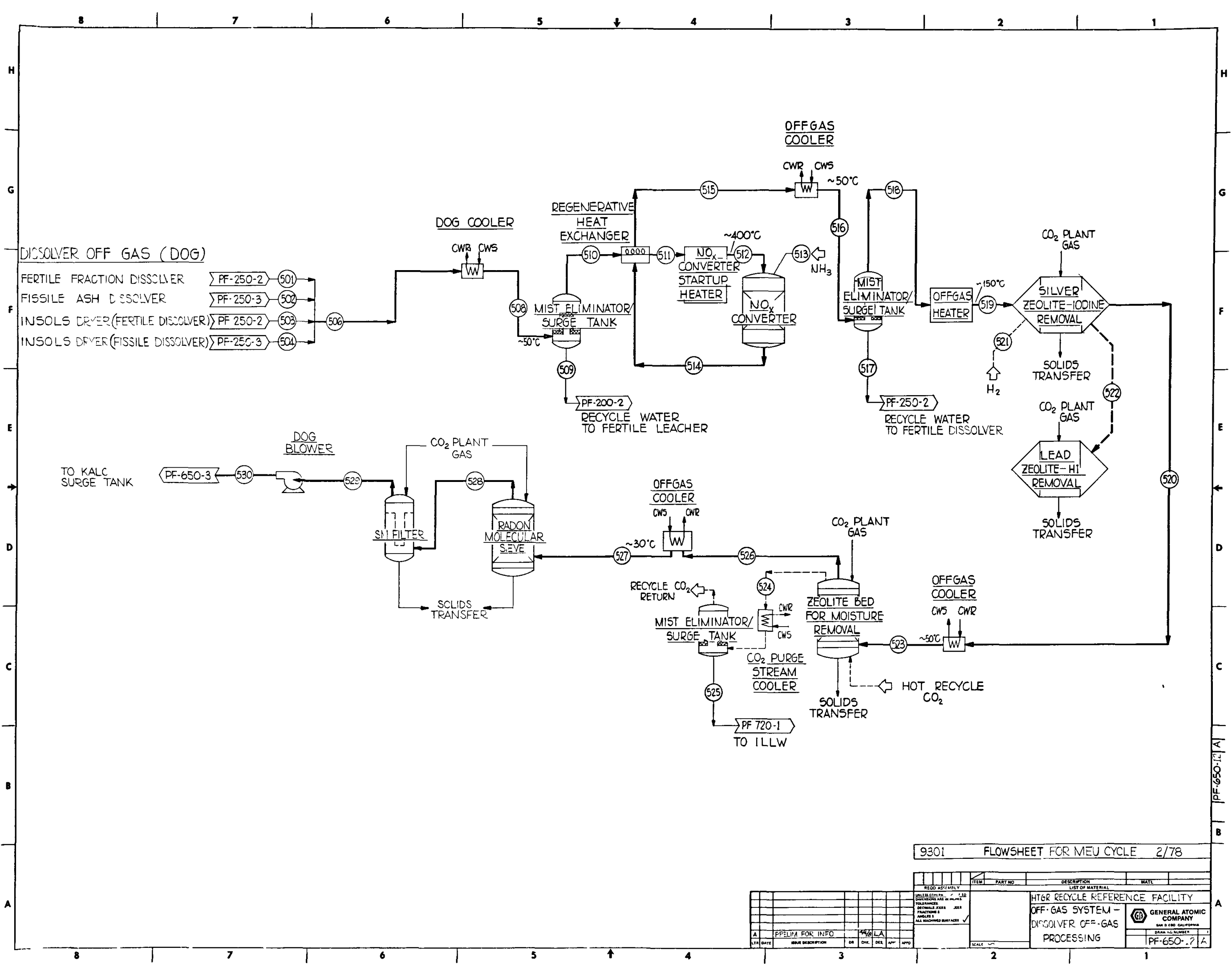




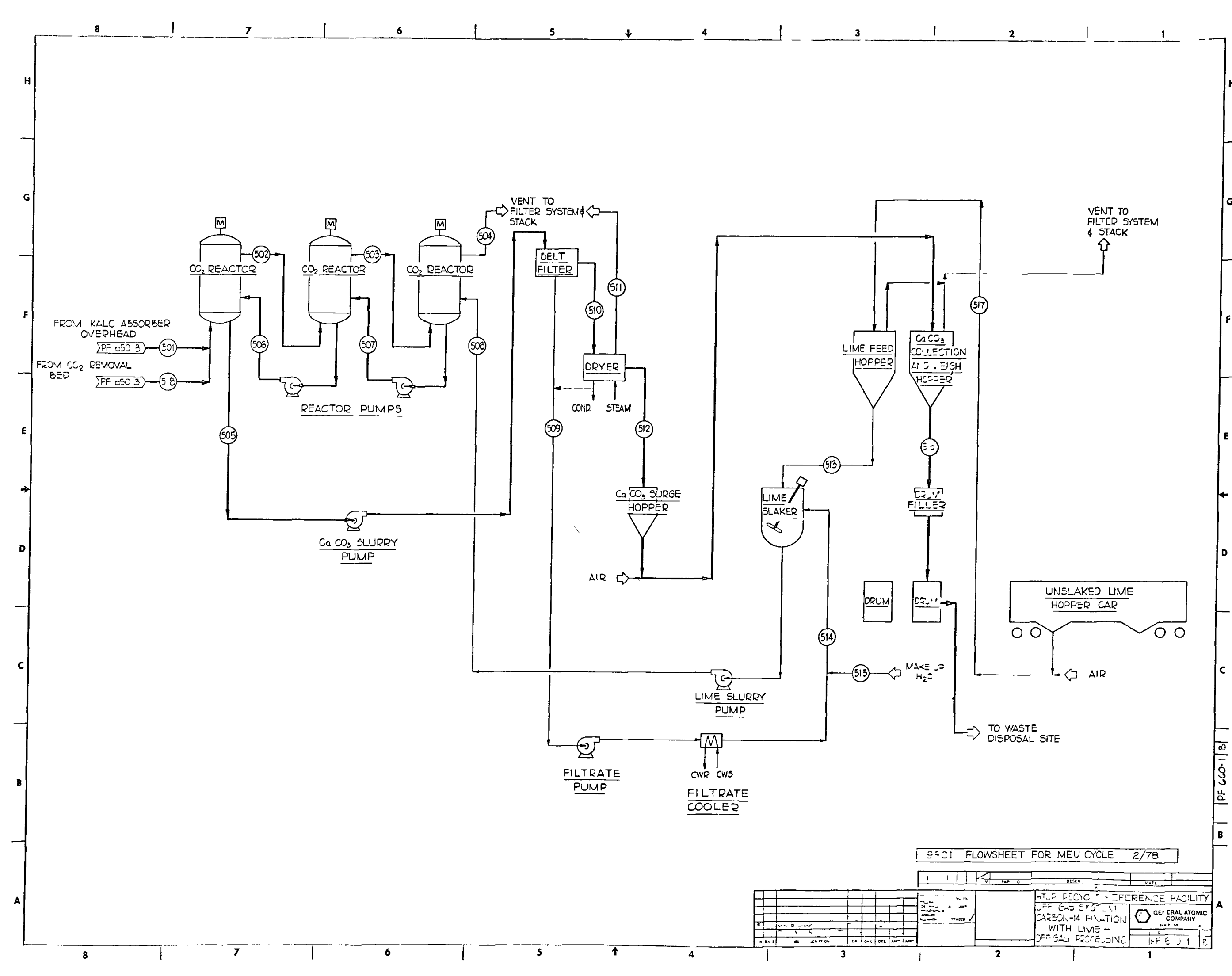


APPENDIX B

HRRF REPROCESSING MATERIAL BALANCE DATA FOR MEU-CYCLE FUELS 
TABLE B-1

MATERIAL BALANCE FOR HEAD-END FUEL RLEMAENT CRUSH - PRIMARY BURN - CLASSTFY (PF-250-1)
(SPENT MAREUP ELEMENTS)

\begin{tabular}{|c|c|c|c|c|c|c|c|c|c|c|c|c|c|c|c|}
\hline & $\begin{array}{c}\begin{array}{c}\text { Crusher } \\
\text { Feed }\end{array} \\
\end{array}$ & $\begin{array}{l}\begin{array}{l}\text { rusher } \\
\text { Product }\end{array} \\
\end{array}$ & $\begin{array}{l}\text { Materia1 } \\
\text { Transport }\end{array}$ & $\begin{array}{c}\begin{array}{c}\text { Burner } \\
\text { Feed }\end{array} \\
\end{array}$ & $\begin{array}{l}\text { Burner } \\
\text { Product } \\
\end{array}$ & $\begin{array}{l}\text { Material } \\
\text { Transport } \\
\end{array}$ & $\begin{array}{r}\text { Burner } \\
\text { Off-gas } \\
\end{array}$ & $\begin{array}{l}\text { Material } \\
\text { Transport }\end{array}$ & $\begin{array}{c}\text { Classifier } \\
\text { Feed }\end{array}$ & 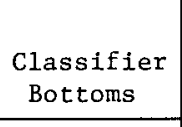 & $\begin{array}{c}\text { Fertile } \\
\text { Fraction } \\
\text { Transport } \\
\end{array}$ & $\begin{array}{l}\text { Classifying } \\
\text { Gas Return } \\
\end{array}$ & $\begin{array}{l}\text { Classifier } \\
\text { Overheads }\end{array}$ & $\begin{array}{c}\text { Fissile } \\
\text { Fraction } \\
\text { Transport } \\
\end{array}$ & $\begin{array}{l}\text { Burner } \\
\text { Feed } \\
\text { Gases } \\
\end{array}$ \\
\hline Stream No. & 101 & 102 & 104 & 105 & 106 & 107 & 110 & 114 & 115 & 123 & 124 & 126 & 129 & 131 & 135 \\
\hline Type of Flow & Batch & Batch & Batch & $\begin{array}{l}\text { Semi- } \\
\text { cont. }\end{array}$ & Batch & Batch & $\begin{array}{l}\text { Semi- } \\
\text { cont. }\end{array}$ & Batch & Batch & Batch & Batch & Batch & Batch & Batch & $\begin{array}{l}\text { Semi- } \\
\text { cont. }\end{array}$ \\
\hline Avg operating $h / \mathrm{d}^{(a)}$ & 11.0 & 11.0 & 3.2 & 20.24 & 0.4 & 0.4 & 24.0 & 0.4 & 4.3 & 4.3 & 0.2 & 4.3 & 4.3 & 0.1 & 24.0 \\
\hline Avg solids flow, $\mathrm{kg} / \mathrm{d}$ & $4952.7^{(\mathrm{b})}$ & 4952.7 & 4952.7 & 4952.7 & 516.5 & 516.5 & TBD & 516.5 & 516.2 & 179.6 & 179.6 & TBD & 336.8 & 336.8 & -- \\
\hline $\begin{array}{l}\text { Avg gas flow, slpd } / 1000 \\
\text { Heat load, } \mathrm{W} / \mathrm{kg}(\mathrm{c}) \\
\text { Activity, } \mathrm{C} i / \mathrm{kg} \\
\text { Bulk density, } \mathrm{g} / \mathrm{cm}^{3}\end{array}$ & $\begin{array}{r}2.4^{(d)} \\
579.0^{(d)} \\
1.29\end{array}$ & \begin{tabular}{|l|l|}
663.7 \\
\end{tabular} & 663.7 & $\begin{array}{c}2.44 \\
579.0 \\
1.12\end{array}$ & $\begin{array}{r}23.4 \\
5552.0 \\
2.7\end{array}$ & 80.4 & 12,300 & 80.4 & $\begin{array}{r}-- \\
23.4 \\
5552.0 \\
2.7\end{array}$ & -- & -- & 726.0 & -- & 27.0 & 11,500 \\
\hline $\begin{array}{l}\text { Physical Components } \\
\text { Fissile particles }\end{array}$ & & & & & & & & & & & & & & & \\
\hline $\begin{array}{l}\text { Whole, } \mathrm{kg} / \mathrm{d} \\
\text { Broken, } \mathrm{kg} / \mathrm{d} \\
\text { Burned-back, } \mathrm{kg} / \mathrm{d} \\
\text { Sic hulls, } \mathrm{kg} / \mathrm{d}\end{array}$ & $\begin{array}{l}443.2 \\
3.12\end{array}$ & $\begin{array}{l}431.6 \\
14.73\end{array}$ & $\begin{array}{l}422.7(\mathrm{e}) \\
23.7\end{array}$ & $\begin{aligned} 422.7 \\
23.7\end{aligned}$ & $\begin{array}{c}12.05 \\
308.7 \\
10.86\end{array}$ & $\begin{array}{c}15.14 \\
305.6 \\
10.86\end{array}$ & & $\begin{array}{c}18.20 \\
302.5 \\
10.9\end{array}$ & $\begin{array}{r}18.2 \\
30.5 \\
10.9\end{array}$ & 6.0 & 6.0 & & $\begin{array}{r}19.7 \\
295.0 \\
10.9\end{array}$ & $\begin{array}{r}19.7 \\
295.0 \\
10.9\end{array}$ & \\
\hline $\begin{array}{l}\text { Fertile particles } \\
\text { Whole, } \mathrm{kg} / \mathrm{d} \\
\text { Broken, } \mathrm{kg} / \mathrm{d} \\
\text { Burned-back, kg/d }\end{array}$ & $\begin{array}{l}311.8 \\
1.25\end{array}$ & $\begin{array}{r}309.3 \\
3.76\end{array}$ & $\begin{array}{r}308.7 \\
4.4\end{array}$ & $\begin{array}{r}308.7 \\
4.38\end{array}$ & $\begin{array}{r}2.68 \\
176.23\end{array}$ & $\begin{array}{r}2.94 \\
176.00\end{array}$ & & $\begin{array}{r}3.20 \\
175.74\end{array}$ & $\begin{array}{r}3.2 \\
175.4\end{array}$ & $\begin{array}{r}0.8 \\
172.8\end{array}$ & $\begin{array}{l}0.8 \\
172.8\end{array}$ & & $\begin{array}{l}2.4 \\
2.6\end{array}$ & $\begin{array}{l}2.4 \\
2.6\end{array}$ & \\
\hline $\begin{array}{l}\text { Graphite, matrix, shim, } \\
\text { and boron, } \mathrm{kg} / \mathrm{d}\end{array}$ & 4193.0 & 4193.0 & 4193.0 & 4193.0 & 6.2 & 6.2 & & 6.2 & 6.2 & & & & 6.2 & 6.2 & \\
\hline Chemical Components & & & & & & & & & & & & & & & \\
\hline $\begin{array}{l}\text { Burnable carbon, } \mathrm{kg} / \mathrm{d} \\
\text { Bound carbon, } \mathrm{kg} / \mathrm{d} \\
\text { Bound oxygen, } \mathrm{kg} / \mathrm{d}\end{array}$ & $\begin{array}{r}4429.0 \\
112.7 \\
41.3\end{array}$ & $\begin{array}{r}\begin{array}{r}4432.0 \\
109.8 \\
41.3\end{array}\end{array}$ & $\begin{array}{r}4434.0 \\
107.5 \\
41.3\end{array}$ & $\begin{array}{r}4434.0 \\
107.5 \\
41.3\end{array}$ & $\begin{array}{r}6.0 \\
102.7 \\
38.7\end{array}$ & $\begin{array}{r}7.0 \\
10.7 \\
38.7\end{array}$ & & $\begin{array}{r}8.0 \\
100.7 \\
38.7\end{array}$ & $\begin{array}{r}8.0 \\
100.7 \\
38.7\end{array}$ & $\left\{\begin{array}{l}\{0.1 \\
27.3\end{array}\right.$ & $\begin{array}{c}0.1\} \\
27.3\end{array}$ & & $\begin{array}{r}8.0 \\
100.6 \\
11.4\end{array}$ & $\begin{array}{r}8.0 \\
10.6 \\
11.4\end{array}$ & \\
\hline $\begin{array}{l}\text { Silicon carbide, } \mathrm{kg} / \mathrm{d} \\
\text { Heavy metal }\end{array}$ & 113.5 & 113.5 & 113.5 & 113.5 & 113.5 & 113.5 & & 113.5 & 113.5 & 2.0 & 2.0 & & 111.5 & 111.5 & \\
\hline $\begin{array}{l}\mathrm{U}(\mathrm{w} / \mathrm{U}-233), \mathrm{kg} / \mathrm{d}(\mathrm{f}) \\
\mathrm{U}(\mathrm{w} / \mathrm{U}-235), \mathrm{kg} / \mathrm{d}) \\
\text { Thorium, } \mathrm{kg} / \mathrm{d} \\
\text { Other, } \mathrm{kg} / \mathrm{d}\end{array}$ & $\begin{array}{r}4.73 \\
79.55 \\
138.5 \\
3.21\end{array}$ & $\begin{array}{r}4.73 \\
79.55 \\
138.5 \\
3.21\end{array}$ & $\begin{array}{c}4.73 \\
79.55 \\
138.5 \\
3.21\end{array}$ & $\begin{array}{r}4.73 \\
79.55 \\
138.5 \\
3.21\end{array}$ & $\begin{array}{c}4.73 \\
79.55 \\
138.5 \\
3.21\end{array}$ & $\begin{array}{r}4.73 \\
79.55 \\
138.5 \\
3.21\end{array}$ & & $\begin{array}{c}49.73 \\
79.55 \\
138.5 \\
3.21\end{array}$ & $\begin{array}{c}49.73 \\
79.55 \\
138.5 \\
3.21\end{array}$ & $\begin{array}{c}4.6 \\
1.49 \\
135.9\end{array}$ & $\begin{array}{c}4.6 \\
1.49 \\
135.9\end{array}$ & & $\begin{array}{c}0.13 \\
78.06 \\
2.6 \\
3.21\end{array}$ & $\begin{array}{c}0.13 \\
78.06 \\
2.6 \\
3.21\end{array}$ & \\
\hline $\begin{array}{l}\text { Fission Products } \\
3 \mathrm{H}, \mathrm{Kr}, \mathrm{I}, \mathrm{Ke}, \mathrm{Rn}, \mathrm{kg} / \mathrm{d} \\
\text { Other, } \mathrm{kg} / \mathrm{d} \\
\text { sulfur }\end{array}$ & $\begin{array}{l}4.007 \\
25.68 \\
0.9\end{array}$ & $\begin{array}{c}4.007 \\
25.68 \\
0.9\end{array}$ & $\begin{array}{l}4.007 \\
25.68 \\
0.9\end{array}$ & $\begin{array}{l}4.007 \\
25.68 \\
0.9\end{array}$ & $\begin{array}{c}3.6 \\
25.68\end{array}$ & $\begin{array}{r}3.6 \\
25.7\end{array}$ & $\begin{array}{r}0.4 \\
25.7 \\
0.9\end{array}$ & $\begin{array}{r}3.6 \\
25.7\end{array}$ & $\begin{array}{r}3.6 \\
25.7\end{array}$ & $\begin{array}{l}2.2 \\
6.0\end{array}$ & $\begin{array}{l}2.2 \\
6.0\end{array}$ & & $\begin{array}{l}1.4 \\
19.7\end{array}$ & $\begin{array}{r}1.4 \\
19.7\end{array}$ & \\
\hline $\begin{array}{l}\text { Boron } \\
\mathrm{O}_{2}, \text { slpd } / 1000 \\
\mathrm{CO}_{2}, \text { s1pd d } 1000 \\
\mathrm{co}, \text { s1pd } / 1000\end{array}$ & 0.2 & 0.2 & 0.2 & 0.2 & 0.2 & 0.2 & $\begin{array}{r}0.2 \\
24.6 \\
10,82.0 \\
1,446\end{array}$ & $\begin{array}{r}0.2 \\
80.4\end{array}$ & 0.2 & & 44.2 & 726.0 & 0.2 & $\begin{array}{r}0.2 \\
27.0\end{array}$ & $\begin{array}{l}7,676 \\
3,824\end{array}$ \\
\hline
\end{tabular}

(a) Exclusive of rework - based on 233 equivalent operating days per year.

(b) LHTGR standard makeup fuel element basis (for 10,000 fuel element/yr throughput).

(c) Decay heat only (excludes process heating and cooling effects).

(d) 180-day cooled fuel elements discharged at reload 5.

(e) Tota1 transport breakage from crusher to burner.

(f) Total uranium in the fertile particle.

(g) Total uranium in the fissile particle. 
TABLE B-2
MATERIAL BALANCE FOR HEAD-END FERTILE FRACTION LEACHING (PF-250-2)

\begin{tabular}{|c|c|c|c|c|c|c|c|c|c|c|c|c|c|c|c|c|c|}
\hline & $\begin{array}{c}\begin{array}{c}\text { Fertile } \\
\text { Leacher } \\
\text { Feed }\end{array} \\
\end{array}$ & $\begin{array}{c}\text { Thorex } \\
\text { Acid } \\
\text { Solu- } \\
\text { tion } \\
\end{array}$ & $\begin{array}{l}\text { Fertile } \\
\text { Leacher } \\
\text { Product } \\
\end{array}$ & & $\begin{array}{l}\text { Leacher } \\
\text { Off-Gas } \\
\end{array}$ & & $\begin{array}{c}\text { Centri- } \\
\text { fuge } \\
\text { Product } \\
\text { Solution } \\
\end{array}$ & $\begin{array}{l}\text { Centri- } \\
\text { fuge } \\
\text { Product } \\
\text { Solids } \\
\end{array}$ & $\begin{array}{c}\text { Poisoned } \\
\text { Dilute } \\
\text { Acid } \\
\end{array}$ & $\begin{array}{c}\text { Repulping } \\
\text { Product }\end{array}$ & $\begin{array}{l}\text { Centri- } \\
\text { fuge } \\
\text { Product } \\
\text { Solution } \\
\end{array}$ & $\begin{array}{c}\text { Fertile } \\
\text { Leach } \\
\text { Product } \\
\text { to SX }\end{array}$ & $\begin{array}{l}\text { Centri- } \\
\text { fuge } \\
\text { Product } \\
\text { Solids } \\
\end{array}$ & $\begin{array}{l}\text { Insols } \\
\text { Products }\end{array}$ & $\begin{array}{l}\text { Insols to } \\
\text { classify }\end{array}$ & $\begin{array}{l}\text { Dryer } \\
\text { off- } \\
\text { Gas }\end{array}$ & $\begin{array}{c}\text { High } \\
\text { Leve1 } \\
\text { Liquid } \\
\text { Waste } \\
\end{array}$ \\
\hline Stream No. & 202 & 203 & 204 & 205 & 206 & 207 & 209 & 210 & 211 & 212 & 214 & 218 & 219 & 220 & 221 & 225 & 226 \\
\hline Type of flow & Batch & Batch & $\begin{array}{l}\text { Semi- } \\
\text { cont. }\end{array}$ & $\begin{array}{l}\text { Semi- } \\
\text { cont. }\end{array}$ & $\begin{array}{l}\text { Semi- } \\
\text { cont. }\end{array}$ & $\begin{array}{l}\text { Semi- } \\
\text { cont. }\end{array}$ & $\begin{array}{l}\text { Semi- } \\
\text { cont. }\end{array}$ & Batch & Batch & $\begin{array}{l}\text { Semi- } \\
\text { cont. }\end{array}$ & $\begin{array}{l}\text { Semi- } \\
\text { cont. }\end{array}$ & Batch & Batch & Batch & Batch & $\begin{array}{l}\text { Semi- } \\
\text { cont. }\end{array}$ & $\begin{array}{l}\text { Semi- } \\
\text { cont. }\end{array}$ \\
\hline $\begin{array}{l}\text { Avg operating } \\
\mathrm{h} / \mathrm{d}(\mathrm{a})\end{array}$ & 0.2 & & $8-12$ & $8-12$ & $8-12$ & $8-12$ & 0.6 & & & & 0.03 & & & 0.003 & 0.003 & TBD & \\
\hline $\begin{array}{l}\text { Avg solids flow, } \\
\mathrm{kg} / \mathrm{d}\end{array}$ & 179.6 & & 7.1 & & & & $0.03^{(\mathrm{b})}$ & 7.1 & & 6.4 & (b) & $0.03^{(b)}$ & 6.4 & 6.4 & 6.4 & & \\
\hline $\begin{array}{l}\text { Avg gas/vapor f flow, } \\
\text { slpd/1000(c) }\end{array}$ & 44.2 & & & 408.1 & 407.4 & & & & & & & & & 0.7 & 0.7 & TBD & \\
\hline $\begin{array}{l}\text { Avg liquid flow, } \\
1 / \mathrm{d}(\mathrm{c})\end{array}$ & & 585.6 & 585.6 & & & 0.7 & 585.1 & 0.5 & 49.0 & 49.5 & 49.0 & 633.6 & 0.5 & & & & 0.5 \\
\hline Heat load, $w / 1^{(d)}$ & & & TBD & & & & TBD & & & TBD & TBD & TBD & TBD & TBD & TBD & & TBD \\
\hline $\begin{array}{l}\text { Activity, Ci/1 } \\
\text { Fissile particles, } \\
\text { kg/d }\end{array}$ & 6.0 & & TBD & TBD & TBD & & TBD & $\begin{array}{l}\text { TBD } \\
6.0\end{array}$ & & TBD & TBD & TBD & $\begin{array}{l}\text { TBD } \\
6.0\end{array}$ & $\begin{array}{l}\text { TBD } \\
6.0\end{array}$ & TBD & & TBD \\
\hline $\begin{array}{l}\text { Fertile particles } \\
\text { kg/d }\end{array}$ & 173.6 & & & & & & & & & & & & & & & & \\
\hline Carbon, g/1 & & & 0.2 & & & & 0.04 & 150.0 & & 1.5 & & 0.05 & 150.0 & 0.11 & 0.11 & & \\
\hline Uranium, $g / 1$ & & & 10.4 & & & & 10.4 & 60.9 & & 0.6 & 0.6 & 9.7 & 0.3 & 0.0002 & 0.0002 & & 0.006 \\
\hline Thorium, $g / 1$ & & & 232.0 & & & & 230.9 & 1357.2 & & 13.7 & 13.1 & 214.2 & 80.0 & 0.06 & 0.06 & & 0.13 \\
\hline $\begin{array}{l}\text { Fission products, } \\
\mathrm{g} / 1(\mathrm{e})\end{array}$ & & & 14.0 & 0.005 & 0.005 & & 13.5 & 585.0 & & 5.9 & 0.4 & 12.5 & 540.0 & 0.4 & 0.4 & & 0.06 \\
\hline $\mathrm{HNO}_{3}, \underline{\mathrm{M}}$ & & 13.0 & 8.5 & & & & 8.8 & & 0.2 & 0.2 & 0.2 & 7.9 & 0.2 & & & & 0.2 \\
\hline $\mathrm{F}^{-}, \frac{\mathrm{M}}{+}$ & & 0.05 & 0.05 & & & & 0.05 & & & & & 0.05 & & & & & \\
\hline $\begin{array}{l}\mathrm{Al}^{+}, \mathrm{M} \\
\mathrm{Cd}^{+}+, \mathrm{M}\end{array}$ & & $\begin{array}{l}0.1 \\
0.075\end{array}$ & $\begin{array}{l}0.1 \\
0.075\end{array}$ & & & & $\begin{array}{l}0.1 \\
0.075\end{array}$ & & 0.075 & 0.075 & 0.075 & $\begin{array}{l}0.1 \\
0.075\end{array}$ & 0.075 & & & & 0.075 \\
\hline Total $\mathrm{No}_{3}^{-}, \underline{\mathrm{M}}$ & & 13.4 & 13.4 & & & & 13.4 & & 0.3 & 0.3 & 0.3 & 12.4 & 0.3 & & & & 0.3 \\
\hline $\mathrm{NO}_{X}$, slpd/1000 & & & & 1.2 & 8.15 & & & & & & & & & & & & \\
\hline $\begin{array}{l}\mathrm{CO}_{2}, \text { slpd/1000 } \\
\text { Air, slpd/1000 }\end{array}$ & & & & 406.9 & 399.3 & & & & & & & & & & & TBD & \\
\hline
\end{tabular}

(a) Exclusive of rework. Based on 233 equivalent operating days/year.

(b) $25 \%$ of free carbon assumed to be in final product (all shown in first centrifuge product).

(c) Operating flow rate.

(d) Decay heat only (exclusive of process heating or cooling).

(e) Includes other heavy metals. 


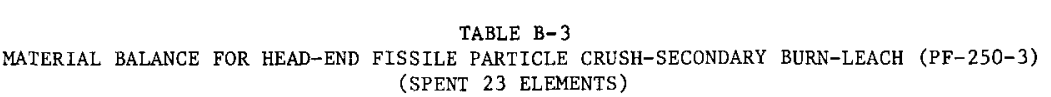

\begin{tabular}{|c|c|c|c|c|c|c|c|c|c|c|c|c|c|c|c|c|c|c|c|c|c|c|c|c|}
\hline & $\begin{array}{l}\text { Spent } 23 \text { 23Rement } \\
\text { Fassile Particlie } \\
\text { Transport } \\
\end{array}$ & $\begin{array}{l}\begin{array}{c}\text { Frssile } \\
\text { Crusther } \\
\text { Feed }\end{array} \\
\text { Fee }\end{array}$ & 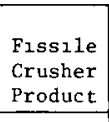 & 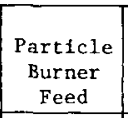 & $\begin{array}{c}\text { Burner } \\
\text { Feed } \\
\text { Gases } \\
\end{array}$ & $\begin{array}{l}\begin{array}{c}\text { Partcle } \\
\text { burner } \\
\text { off-gas }\end{array} \\
\text { off }\end{array}$ & $\begin{array}{c}\begin{array}{c}\text { Particle } \\
\text { Burner } \\
\text { Product }\end{array} \\
\text { Protes }\end{array}$ & $\begin{array}{c}\text { Burner } \\
\text { Product } \\
\text { Transport }\end{array}$ & $\begin{array}{c}\begin{array}{c}\text { Fissile } \\
\text { Leacher } \\
\text { Feed }\end{array} \\
\text { Feed }\end{array}$ & $\begin{array}{c}\text { Poisoned } \\
\text { Nitricic Acld } \\
\text { Solution } \\
\end{array}$ & off-gas & $\begin{array}{c}\text { Condensate } \\
\text { Return }\end{array}$ & $\begin{array}{l}\text { Fissie } \\
\text { Leacher } \\
\text { Off-gas }\end{array}$ & $\begin{array}{l}\begin{array}{c}\text { Fissile } \\
\text { Leacher } \\
\text { Product }\end{array} \\
\end{array}$ & $\begin{array}{c}\begin{array}{c}\text { Centrifuge } \\
\text { Solution }\end{array} \\
\text { Solon }\end{array}$ & 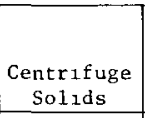 & 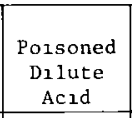 & \begin{tabular}{|c|} 
Repulping \\
Product \\
\end{tabular} & 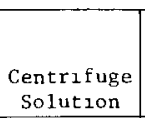 & 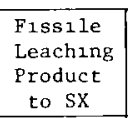 & 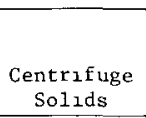 & $\begin{array}{l}\text { Insons } \\
\text { Dryer } \\
\text { provect }\end{array}$ & 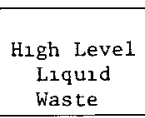 & $\begin{array}{l}\text { Insosis } \\
\text { ofyer } \\
\text { off f-gas }\end{array}$ \\
\hline Stream No. & 301 & 304 & 307 & \begin{tabular}{|l|}
308 \\
\end{tabular} & 309 & 310 & 311 & 312 & 313 & 314 & 315 & 316 & \begin{tabular}{|l|l|}
317 \\
\end{tabular} & 318 & 320 & 321 & 322 & \begin{tabular}{|l|}
323 \\
\end{tabular} & 325 & 327 & 328 & 332 & 334 & 335 \\
\hline Avg operating $h / d^{(a)}$ & Darca & Daten & (28 & satch & Batch & Batch & Batch & Batch & Batch & Batch & Batch & Batch & Batch & Batch & Batch & Batch & Batch & Batch & Batch & Batch & Batch & Batch & Batch & Batch \\
\hline Avg sol11s $\mathrm{f} 10 \mathrm{w}, \mathrm{kg} / \mathrm{d}$ & $\begin{aligned} 0.1 \\
113.6\end{aligned}$ & $\begin{array}{r}2.8 \\
113.6\end{array}$ & $\begin{array}{r}2.8 \\
113.6\end{array}$ & $\begin{array}{r}2.8 \\
113.6\end{array}$ & $\begin{array}{l}12,0 \\
0\end{array}$ & $\begin{array}{c}12.0 \\
\mathrm{TBD}\end{array}$ & $\begin{array}{r}1.6 \\
66.6\end{array}$ & $\begin{array}{l}0.1 \\
66.6\end{array}$ & 7.00 & 7.0 & 14.0 & 14.0 & 14.0 & 53.4 & $\begin{array}{l}0.5 \\
0.1^{(b)}\end{array}$ & 53.3 & & 53.1 & 0.3 & 0.1 & 53.1 & $\begin{array}{c}0.06 \\
53.1\end{array}$ & Neg1. & Negl. \\
\hline Avg gas/vapor flow, slpd/1000 & 14.0 & & & & 208.3 & 209.7 & 00.6 & $\begin{array}{l}15.0 \\
15.0\end{array}$ & 00.0 & & 211.4 & & 211.3 & 33.4 & & 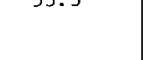 & & . & & & & & & TBD \\
\hline Avg 1 lquid f flow, $1 / \mathrm{d}$ & & & & & & & & & & 469.0 & & 0.24 & & 469.0 & 463.7 & 5.3 & 380.0 & 3853 & 380.0 & 463.7 & 5.3 & -- & 5.3 & \\
\hline Heat $10 \mathrm{nd}, w / 1^{(\mathrm{cc})}$ or $\mathrm{w} / \mathrm{kg}$ & TBD & TBD & TBD & TBD & & TBD & TBD & твD & твр & & Neg1. & & Neg1. & TBD & твD & TBD & & TBD & TBD & TBD & TBD & TBD & TBD & TBD \\
\hline Actavity, $\mathrm{C}_{2} / 1$ or $\mathrm{Ci} / \mathrm{kg}$ & TBD & TBD & TBD & твD & & TBD & TBD & TBD & TBD & & Neg1. & & Neg1. & твD & TBD & тво & & TBD & TBD & TBD & TBD & TBD & TBD & TBD \\
\hline Burned-back fissile partzcles, kg/d & 99.9 & 99.9 & 1.0 & 1.0 & & & 0.9 & 0.9 & 0.9 & & & & & 0.9 & & 09 & & 0.9 & & & 0.9 & 0.9 & & \\
\hline Broken F1ssile partacles, kg/d & 6.2 & 6.2 & 105.1 & 105.1 & & & -- & -- & -- & & & & & -- & & 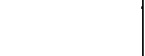 & & -- & & & - & -- & & \\
\hline S1C hu1ls, kg/d & 3.7 & 3.7 & 3.7 & 3.7 & & & 50.0 & 50.0 & 50.0 & & & & & 50.0 & & 50.0 & & 500 & & & 50.0 & 50.0 & & \\
\hline Burned-back fertz1e partzcles, $\mathrm{kg} / \mathrm{d}$ & 1.7 & 1.7 & 1.7 & 1.7 & & & 1.7 & 1.7 & 1.7 & & & & & 1.7 & & 1.7 & & 1.7 & & & 1.7 & 17 & & \\
\hline $\mathrm{v}_{3} \mathrm{~g}_{8}, \mathrm{~kg} / \mathrm{d}$ & & & & & & & 4.44 & 4.44 & 4.44 & & & & & 0.15 & -- & 0.15 & & 0.1 & & & 0.1 & 0.1 & & \\
\hline $\begin{array}{l}\text { Other solids, } \mathrm{kg} / \mathrm{d}^{(\mathrm{e})} \\
\text { In Solution. }\end{array}$ & 2.0 & 2.0 & 2.0 & 20 & & & $9.6^{(\mathrm{d})}$ & 9.6 & 9.6 & & & & & 06 & 0.1 & 0.5 & & 04 & & 0.1 & 0.4 & 0.4 & & \\
\hline Urannum $g / 1$ & & & & & & & & & & & & & & 80 & 8.0 & 8.0 & & 0.2 & 0.2 & 8.0 & 0.2 & & TBD & \\
\hline Thor um, $g / 1$ & & & & & & & & & & & & & & Neg1. & Neg1. & Neg1. & & Negi. & Neg1. & Neg1. & Neg1. & & тBD & \\
\hline $\begin{array}{l}\text { Plutonum, } g / 1 \\
\text { Other heavy metals, } \mathrm{g} / 1\end{array}$ & & & & & & & & & & & & & & $\begin{array}{l}0.4 \\
0.4\end{array}$ & $\begin{array}{l}0.4 \\
0.4\end{array}$ & $\begin{array}{l}0.4 \\
0.4\end{array}$ & & $\begin{array}{l}0.01 \\
0.01\end{array}$ & $\begin{array}{l}0.01 \\
0.01\end{array}$ & $\begin{array}{l}0.4 \\
0.4\end{array}$ & $\begin{array}{l}0.01 \\
0.01\end{array}$ & & $\begin{array}{l}\mathrm{TBD} \\
\mathrm{TBD}\end{array}$ & \\
\hline $\begin{array}{l}\text { F1ssion Products } \\
3_{3}\end{array}$ & & & & & & & & & & & & & & & & & & & & & & & & \\
\hline $\begin{array}{l}\text { 3, Kr, I, Xe, Rn, g/1 } \\
\text { other, g/1 }\end{array}$ & & & & & & & TBD & $\begin{array}{l}\text { TBD } \\
\text { TBD }\end{array}$ & ${ }_{\mathrm{TBD}}^{\mathrm{TBD}}$ & & Neg1. & & & $\begin{array}{l}\text { Neg1. } \\
11.7\end{array}$ & $\begin{array}{l}\text { Neg1. } \\
11 .\end{array}$ & Neg1. & & $\begin{array}{l}\mathrm{Neg1.} \\
0,3\end{array}$ & Neg1 & Negi. & Neg1. & & & \\
\hline Boron, $8 / 1$ & & & & & & & & & & & & & & 0.09 & 0.09 & 0.09 & & 0.001 & 0.001 & 0.09 & 0.001 & & TBD & \\
\hline $\mathrm{HNO}_{3}, \underline{\underline{M}}$ & & & & & & & & & & 2.5 & & & & 2.0 & 2.0 & 2.0 & 0.2 & 0.2 & 0.2 & 2.0 & 0.2 & & тво & \\
\hline $\mathrm{Cd}^{\mathrm{d}}, \underline{\underline{M}}$ & & & & & & & & & & 0.075 & & & & 0.075 & 0.075 & 0.075 & 0.075 & 0.075 & 0.075 & 0.075 & 0.075 & & TBD & \\
\hline Total $\mathrm{No}_{3}^{-}, \underline{\mathrm{M}}$ & & & & & & & & & & 2.5 & & & & & 2.5 & 2.5 & 0.3 & 0.3 & 0.3 & 2.5 & 0.3 & TBD & TBD & \\
\hline $\begin{array}{l}\mathrm{o}_{2}, \mathrm{~s} 1 \mathrm{pd} / 1000 \\
\mathrm{co}_{2}, \mathrm{~s} 1 \mathrm{pd} / 1000\end{array}$ & 14.0 & & & & $\begin{array}{r}94.1 \\
1142\end{array}$ & $\begin{array}{l}29.1 \\
171.6\end{array}$ & TBD & 15.0 & & & & & & & & & & & & & & & & TBD \\
\hline 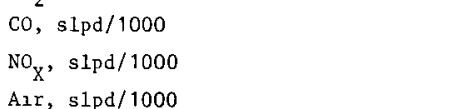 & & & & & & 9.0 & & & & & $\begin{array}{c}0.24 \\
211.2\end{array}$ & & 0.11 & & & & & & & & & твD & & сво \\
\hline A.r, s1pd/1000 & & & & & & & & & & & 211.2 & & 211.2 & & & & & & & & & & & TBD \\
\hline
\end{tabular}

${ }^{(a)}$ Exclusive of rework. Based on 233 equivalent operating days per year.

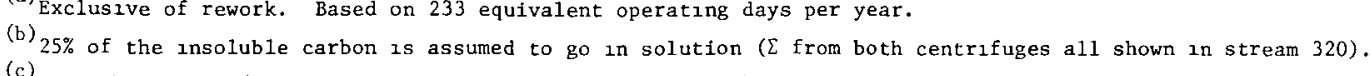

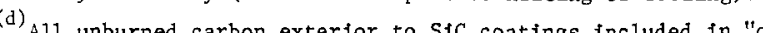

associated w1th SAC Hu11s included with hu11s. $\mathrm{B}_{2} \mathrm{O}_{3}$ included in other solids. 
TABLE B-4
MATERIAL BALANCE FOR OFF-GAS SYSTEM - BURNER OFF-GAS PROCESSTNG (PF-650-11)

\begin{tabular}{|c|c|c|c|c|c|c|c|c|c|c|c|c|c|c|c|}
\hline & $\begin{array}{l}\text { Primary } \\
\text { Burner } \\
\text { Off-gas } \\
\text { (PBOG) }\end{array}$ & $\begin{array}{c}\text { To } \\
\text { Semivolatile } \\
\text { FP Removal }\end{array}$ & $\begin{array}{c}\text { To Iodine } \\
\text { Remova1 } \\
\text { Unit } \\
\end{array}$ & $\begin{array}{c}\text { To Sulfur } \\
\text { Removal } \\
\text { Unit } \\
\end{array}$ & $\begin{array}{l}\text { To co/HT } \\
\text { Oxidizer }\end{array}$ & $\begin{array}{l}\text { To Tritium } \\
\text { Remova1 } \\
\text { Unit }\end{array}$ & $\begin{array}{l}\text { To Radon } \\
\text { Holdup } \\
\text { Unit }\end{array}$ & $\begin{array}{l}\text { To KALC } \\
\text { Surge } \\
\text { Tank } \\
\end{array}$ & $\begin{array}{l}\text { Secondary } \\
\text { Burner } \\
\text { off-gas } \\
\text { (SBOG) } \\
\end{array}$ & $\begin{array}{c}\text { To } \\
\text { Semivolatile } \\
\text { FP Removal } \\
\end{array}$ & $\begin{array}{c}\text { To Iodine } \\
\text { Removal } \\
\text { Unit }\end{array}$ & $\begin{array}{l}\text { To Co/HT } \\
\text { Oxidizer }\end{array}$ & $\begin{array}{c}\text { To Tritium } \\
\text { Removal } \\
\text { Unit }\end{array}$ & $\begin{array}{c}\text { To Radon } \\
\text { Holdup } \\
\text { Unit From } \\
\text { SBOG } \\
\end{array}$ & $\begin{array}{l}\text { To KALC } \\
\text { Process }\end{array}$ \\
\hline Stream No. & 101 & 104 & 107 & 111 & 113 & 117 & 120 & 123 & 151 & 152 & 155 & 159 & 162 & 164 & 167 \\
\hline Type of flow & Semicont. & Semicont. & Semicont. & Semicont. & Semicont. & Semicont. & Semicont. & Semicont. & Batch & Batch & Batch & Batch & Batch & Batch & Batch \\
\hline Avg operating $h / d^{(a)}$ & & & & & & & & & 24 & 24 & 24 & 24 & 24 & 24 & 24 \\
\hline Avg gas flow, $\mathrm{slpd} / 1000^{(\mathrm{b})}$ & $16,311^{(e)}$ & 16,311 & 16,311 & 16,311 & 16,311 & 16,325 & 16,325 & 16,325 & $416^{(\mathrm{e})}$ & 416 & 416 & 416 & 416 & 416 & 416 \\
\hline Heat load, $w / 1^{(c)}$ & & TBD & $\mathrm{TBD}$ & $\mathrm{TBD}$ & TBD & TBD & TBD & TBD & TBD & $\mathrm{TBD}$ & TBD & TBD & TBD & TBD & TBD \\
\hline Activity, $\mathrm{Ci} / 1$ & $>2.4(-4)$ & $>2.4(-4)$ & $>2.4(-4)$ & $>2.4(-4)$ & $>2.4(-4)$ & $>2.4(-4)$ & $>1.5 \quad(-4)$ & $>1.5(-4)$ & $>3.4(-2)$ & $>3.4(-2)$ & $>3.4(-2)$ & $>3.4(-2)$ & $>3.4(-2)$ & $3.4(-2)$ & $3.4(-2)$ \\
\hline $\mathrm{o}_{2}$, s1pd/1000 & & & & & & 62.7 & 62.7 & 62.7 & & 58 & & 58 & 58 & 58 & 58 \\
\hline $\mathrm{Co}_{2}, \mathrm{~s} 1 \mathrm{pd} / 1000$ & 14,892 & 14,892 & 14,892 & 14,892 & 14,892 & 16,235 & 16,235 & 16,235 & 340 & 340 & 340 & 340 & 358 & 358 & 358 \\
\hline co, slpd/1000 & 1,370 & 1,370 & 1,370 & 1,370 & 1,370 & 27.4 & 27.4 & 27.4 & 18 & 18 & 18 & 18 & 0.4 & 0.4 & 0.4 \\
\hline $\mathrm{No}_{\mathrm{x}}$, slpd/1000 & & & & & & & & & & & & & & & \\
\hline Air, slpd/1000 & & & & & & & & & & & & & & & \\
\hline $\mathrm{NH}_{3}$, slpd/1000 & & & & & & & & & & & & & & & \\
\hline $\begin{array}{l}\mathrm{N}_{2}, \text { slpd/1000 } \\
\text { Sulfur, g/1 }\end{array}$ & $5.6(-5)$ & $5.6(-5)$ & $5.6(-5)$ & $5.6(-5)$ & $5.6(-7)$ & $5.6(-7)$ & $5.6(-7)$ & $5.6(-7)$ & $1.1(-5)$ & $1.1(-5)$ & $1.1(-5)$ & $1.1(-5)$ & $1.1(-5)$ & $1.1(-5)$ & $1.1(-5)$ \\
\hline Carbon-14, g/1 ${ }^{(\mathrm{d})}$ & $1.6(-6)$ & $1.6(-6)$ & $1.6(-6)$ & $1.6(-6)$ & $1.6(-6)$ & $1.6(-6)$ & $1.6(-6)$ & $1.6(-6)$ & $8.3(-7)$ & $8.3(-7)$ & $8.3(-7)$ & $8.3(-7)$ & $8.3(-7)$ & $8.3(-7)$ & $8.3(-7)$ \\
\hline Radon, g/1 & TBD & TBD & TBD & TBD & TBD & TBD & TBD & TBD & TBD & TBD & TBD & TBD & TBD & TBD & TBD \\
\hline Tritium, $g / 1$ & $9.1(-9)$ & $9.1(-9)$ & $9.1(-9)$ & $9.1(-9)$ & $9.1(-9)$ & $9.1(-9)$ & $9.1(-12)$ & $9.1(-12)$ & $6.4(-8)$ & $6.4(-8)$ & $6.4(-8)$ & $6.4(-8)$ & $6.4(-8)$ & $6.4(-11)$ & $6.4(-11)$ \\
\hline Krypton, $g / 1$ & $2.4(-6)$ & $2.4(-6)$ & $2.4(-6)$ & $2.4(-6)$ & $2.4(-6)$ & $2.4(-6)$ & $2.4(-6)$ & $2.4(-6)$ & $5.6(-4)$ & $5.6(-4)$ & $5.6(-4)$ & $5.6(-4)$ & $5.6(-4)$ & $5.6(-4)$ & $5.6(-4)$ \\
\hline Xenon, g/1 & $2.1(-5)$ & $2.1(-5)$ & $2.1(-5)$ & $2.1(-5)$ & $2.1(-5)$ & $2.1(-5)$ & $2.1(-5)$ & $2.1(-5)$ & $5.8(-3)$ & $5.8(-3)$ & $5.8(-3)$ & $5.8(-3)$ & $5.8(-3)$ & $5.8(-3)$ & $5.8(-3)$ \\
\hline Iodine, $g / 1$ & $6.3(-7)$ & $6.3(-7)$ & $6.3(-7)$ & $6.3(-10)$ & $6.3(-10)$ & $6.3(-10)$ & $6.3(-10)$ & $6.3(-10)$ & $1.9(-4)$ & $1.9(-4)$ & $1.9(-4)$ & $1.9(-7)$ & $1.9(-7)$ & $1.9(-7)$ & $1.9(-7)$ \\
\hline Other FP, $g / 1$ & TBD & TBD & TBD & TBD & TBD & TBD & TBD & TBD & TBD & TBD & TBD & TBD & TBD & TBD & TBD \\
\hline Other particulates, $g / 1$ & TBD & TBD & TBD & TBD & TBD & TBD & TBD & TBD & TBD & TBD & TBD & TBD & TBD & TBD & TBD \\
\hline
\end{tabular}

(a) Exclusive of rework - based on 233 equivalent operating days per year.

(b) Exclusive of filter blowback and bed regeneration $\mathrm{CO}_{2}$ additions. Not including impurity volumes.

(c) Decay heat only (exclusive of process heating or cooling).

(d) Carbon-14 level has increased by $80 \%$ in PBOG and 127 times in SBOG as a result of using recycle $\mathrm{CO}_{2}$ from KALC system.

value has been adjusted to include miscellaneous gas stream inputs; e.g., transport gas bleed or coolant purge. 
TABLE B-5

MATERIAL BALANCE FOR OFF-GAS SYSTEM - DISSOLVER OFF-GAS PROCESSING (PF-650-12)

\begin{tabular}{|c|c|c|c|c|c|c|c|c|c|}
\hline & $\begin{array}{c}\text { Fertile } \\
\text { Fraction } \\
\text { Dissolver } \\
\text { Off-Gas }\end{array}$ & $\begin{array}{c}\text { Fissile Ash } \\
\text { Dissolver } \\
\text { Off-Gas }\end{array}$ & $\begin{array}{c}\text { Insol Dryer } \\
\text { (Fertile } \\
\text { Dissolution) }\end{array}$ & $\begin{array}{c}\text { Insol Dryer } \\
\text { (Fissile } \\
\text { Dissolution) }\end{array}$ & $\begin{array}{c}\text { To Dissolver } \\
\text { Off-Gas } \\
\text { Processing }\end{array}$ & $\begin{array}{c}\text { To } \mathrm{NO}_{\mathrm{X}} \\
\text { Converter }\end{array}$ & $\begin{array}{l}\text { Ammonia } \\
\text { Addition }\end{array}$ & $\begin{array}{c}\text { To Iodine } \\
\text { Removal }\end{array}$ & $\begin{array}{l}\text { To KALC } \\
\text { Process } \\
\end{array}$ \\
\hline Stream No. & 501 & 502 & 503 & 504 & 506 & 512 & 513 & 519 & 530 \\
\hline Type of flow & $\begin{array}{l}\text { Semi- } \\
\text { cont. }\end{array}$ & Batch & $\begin{array}{l}\text { Semi- } \\
\text { cont. }\end{array}$ & Batch & $\begin{array}{l}\text { Semi- } \\
\text { cont. }\end{array}$ & $\begin{array}{l}\text { Semi- } \\
\text { cont. }\end{array}$ & $\begin{array}{l}\text { Semi- } \\
\text { cont. }\end{array}$ & $\begin{array}{l}\text { Semi- } \\
\text { cont. }\end{array}$ & $\begin{array}{l}\text { Semi- } \\
\text { cont. }\end{array}$ \\
\hline Avg operating $h / d^{(a)}$ & 14 & $8-12$ & $\mathrm{TBD}$ & TBD & 14 & 14 & 14 & 14 & 14 \\
\hline Avg gas flow, $s 1 p d / 1000^{(b)}$ & 407.4 & 211.3 & TBD & TBD & 618.7 & 618.7 & 8.2 & 617.4 & 617.4 \\
\hline Heat load, $W / 1^{(c)}$ & TBD & $\mathrm{TBD}$ & $\mathrm{TBD}$ & $\mathrm{TBD}$ & $\mathrm{TBD}$ & TBD & 0 & $\mathrm{TBD}$ & $\mathrm{TBD}$ \\
\hline Activity, Ci/1 & $>2.1 \quad(-2)$ & $>9.0(-4)$ & TBD & $\mathrm{TBD}$ & $>1.4(-2)$ & $>1.4(-2)$ & & $>1.4(-2)$ & $>1.4(-2)$ \\
\hline${ }^{N O} \mathrm{X}, \operatorname{slpd} / 1000^{(\mathrm{d})}$ & 8.1 & 0.11 & & & 8.2 & 8.2 & 0 & $8.2(-2)$ & $8.2(-2)$ \\
\hline $\mathrm{CO}_{2}, \mathrm{~s} 1 \mathrm{pd} / 1000$ & 399.3 & 211.2 & & & 610.5 & 610.5 & 0 & 610.5 & 610.5 \\
\hline $\mathrm{NH}_{3}$, slpd $/ 1000$ & -- & -- & & & -- & -- & & $8.2(-2)$ & $8.2(-2)$ \\
\hline $\mathrm{N}_{2}, \operatorname{slpd} / 1000$ & 0 & 0 & & & 0 & 0 & 0 & 6.9 & 6.9 \\
\hline Radon, g/1 & $\mathrm{TBD}$ & $\mathrm{TBD}$ & & & $\mathrm{TBD}$ & $\mathrm{TBD}$ & -- & $\mathrm{TBD}$ & $\mathrm{TBD}$ \\
\hline Krypton, $\mathrm{g} / 1$ & $2.9(-4)$ & $1.2(-5)$ & & & $2.0(-4)$ & $2.0(-4)$ & -- & $2.0(-4)$ & $2.0(-4)$ \\
\hline Xenon, $g / 1$ & $1.7(-3)$ & $7.1(-5)$ & & & $1.1(-3)$ & $1.1(-3)$ & -- & $1.1(-3)$ & $1.1(-3)$ \\
\hline Iodine, $\mathrm{g} / 1$ & $1.0(-4)$ & $4.9(-6)$ & & & $6.8(-5)$ & $6.8(-5)$ & -- & $6.8(-5)$ & $6.8(-8)$ \\
\hline
\end{tabular}

(a) Exclusive of rework - based on 233 equivalent operating days per year.

(b) Exclusive of moisture content.

(c) Decay heat only (exclusive of process heating or cooling).

(d) $2 \% \mathrm{NO}_{\mathrm{X}}$ from fertile dissolver is assumed since the fertile dissolver is sparged with No with $\mathrm{CO}_{2}$ (composition $\mathrm{TBD}$ ). 
TABLE B-6

YIIRI 1 I I WW FOR OFF-GIS SYSIFY - KRYPION ABSORPTION IN I IQL ID $\mathrm{CO}_{2}$ (KALC) vtF-CiLS PROCI SSING (PF-650-3)

\begin{tabular}{|c|c|c|c|c|c|c|c|c|}
\hline & 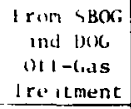 & $\begin{array}{c}\text { From } \mathrm{PBOG} \\
\text { Of } \mathrm{f}-\mathrm{Ga} \\
\text { Treatment }\end{array}$ & $\begin{array}{c}\text { To MLC } \\
\text { Compressors }\end{array}$ & $\begin{array}{l}\text { To Absorber/ } \\
\text { Fractionator }\end{array}$ & $\begin{array}{c}\text { To } \\
\mathrm{MS}-\mathrm{CO}_{2} \\
\text { Remova1 }\end{array}$ & $\begin{array}{c}\text { To } \\
\text { Krypton } \\
\text { Storage }\end{array}$ & To Stack & $\begin{array}{l}\quad \text { To } \\
\text { Carbon- } 14 \\
\text { Fixation }\end{array}$ \\
\hline Stream No & 200 & 201 & $202^{(a)}$ & $208^{(b)}$ & 218 & 233 & 237 & 245 \\
\hline Type of flow & $\begin{array}{l}\text { Seth } 1- \\
\text { cont. }\end{array}$ & $\begin{array}{l}\text { Semi- } \\
\text { cont. }\end{array}$ & $\begin{array}{l}\text { Semi- } \\
\text { cont. }\end{array}$ & $\begin{array}{l}\text { Semi- } \\
\text { cont. }\end{array}$ & $\begin{array}{l}\text { Sem1- } \\
\text { cont. }\end{array}$ & $\begin{array}{l}\text { Semi- } \\
\text { cont. }\end{array}$ & $\begin{array}{l}\text { Semi- } \\
\text { cont. }\end{array}$ & $\begin{array}{l}\text { Semi- } \\
\text { cont. }\end{array}$ \\
\hline Avg operating $h / d^{(c)}$ & 24 & 24 & 24 & 24 & 24 & 24 & 24 & 24 \\
\hline Avg gas $110 w$, slpd $/ 1000^{(d)}$ & $<1035$ & 16,325 & 17,360 & 17,360 & 357.1 & 0.2 & $5.9(-1)$ & 8623.9 \\
\hline Heat lodd, $W / 1^{(e, f)}$ & ГBD & TBD & TBD & TBD & TBD & TBD & TBD & TBD \\
\hline Activity, $C_{1} / 1^{(\mathrm{f})}$ & $2.2(-2)$ & $1.5(-4)$ & $1.45(-3)$ & $1.45(-3)$ & $7.0(-2)$ & 125 & TBD & $2.92(-5)$ \\
\hline $0_{2}, s 1_{p d} / 1000$ & 58 & 62.7 & 120.7 & 120.7 & $3.8(-1)$ & Neg 1 & Neg1 & 120.7 \\
\hline $\mathrm{CO}_{2}, \operatorname{slpd} / 1000$ & 969 & 16,235 & 17,204 & 17,204 & 5.84 & Negl & Negl & $8468.3^{(\mathrm{g})}$ \\
\hline co, slpd/1000 & 0.4 & 27.4 & 27.8 & 27.8 & $8.8(-2)$ & Negl & Negl & 27.8 \\
\hline $\mathrm{N}_{2}$, slpd $/ 1000$ & 6.9 & 0 & 363.3 & 363.3 & 350.1 & 0.1 & Neg1 & 363.3 \\
\hline Krypton, slpd/1000 & $9.45(-2)$ & $1.03(-2)$ & $1.05(-1)$ & $1.05(-1)$ & $1.04(-1)$ & 0.1 & $1.0(-3)$ & $1.05(-3)$ \\
\hline Xenon, slpd $/ 1000$ & $5.37(-1)$ & $5.86(-2)$ & $5.96(-1)$ & $5.96(-1)$ & $5.9(-1)$ & $5.0(-3)$ & $5.9(-1)$ & $5.96(-3)$ \\
\hline No $_{x}$, slpd $/ 1000$ & $8.2(-2)$ & 0 & $8.2(-2)$ & $8.2(-2)$ & Neg 1 & Neg1 & Neg 1 & $8.2(-2)$ \\
\hline $\mathrm{NH}_{3}$, slpd $/ 1000$ & $8.2(-2)$ & 0 & $8.2(-2)$ & $8.2(-2)$ & Neg1 & Negl & Negl & $8.2(-2)$ \\
\hline Sulfur, $g / d^{(h)}$ & $4.4(-6)$ & $5.6(-7)$ & $7.9(-7)$ & $7.9(-7)$ & TBD & Negl & Neg1 & TBD \\
\hline Carbon- $14, \mathrm{~g} / 1$ & $1.3(-6)$ & $1.6(-6)$ & $1.6(-6)$ & $1.6(-6)$ & $1.63(-6)$ & Neg1 & Neg 1 & $1.6(-6)$ \\
\hline Radon, $g / 1$ & I BD & TBD & TBD & $\mathrm{TBD}$ & TBD & TBD & TBD & TBD \\
\hline Tritium, $g / 1$ & Neg1 & $9.1(-12)$ & $8.6(-12)$ & $8.6(-12)$ & TBD & Neg 1 & Neg 1 & TBD \\
\hline Krypton, $\mathrm{g} / \mathrm{l}$ & $3.4(-4)$ & $2.4(-6)$ & $2.3(-5)$ & $2.3(-5)$ & $5.5(-2)$ & 1.90 & $6.4(-3)$ & $4.6(-7)$ \\
\hline Xenon, g/l & $3.0(-3)$ & $2.1(-5)$ & $2.0(-4)$ & $2.0(-4)$ & $4.9(-1)$ & $1.5(-1)$ & 5.8 & $4.0(-6)$ \\
\hline Iodine, $g / 1$ & $1.2(-7)$ & $6.3(-10)$ & $7.7(-9)$ & $7.7(-9)$ & TBD & Neg 1 & Negl & $\mathrm{TBD}$ \\
\hline Other $\mathrm{FP}, \mathrm{g} / 1$ & $\mathrm{TBD}$ & $\mathrm{TBD}$ & $\mathrm{TBD}$ & TBD & TBD & $\mathrm{TBD}$ & TBD & TBD \\
\hline $\begin{array}{l}\text { Other particulates or } \\
\text { contaminants, } \mathrm{g} / 1\end{array}$ & $T B D$ & TBD & TBD & $\mathrm{TBD}$ & TBD & TBD & TBD & $T B D$ \\
\hline
\end{tabular}

(a)" $>$ " and "<" designations have been dropped in 202 and following stream as insols; gas dryer flows are considered negilgible in the large system.

(b) All terms expressed in terms of standard tempexature and pressure throughout.

(c) Exclusive of rework -- based on 233 equivalent operating days.

(d) Exclusive of filter blowback and bed regeneration $\mathrm{CO}_{2}$ additions.

(e) Decay heat only (excludes process heating and cooling).

(f) Exclusive of any activity contributed by any semivolatiles still in stream.

(g) Excluding $\mathrm{CO}_{2}$ makeup (220).

(h) Exclusive of any $S B O G$ sulfur content. 
ABLE B-7

MATLRIAL BALANCE FOR OFF-GAS SYSTEM - CARBON-14 FIXATION WITH LIME OFF-GAS PROCESSINC (PF-660-1)

\begin{tabular}{|c|c|c|c|c|c|c|c|c|c|c|c|c|}
\hline & $\begin{array}{l}\text { From KALC } \\
\text { Absorber }\end{array}$ & $\begin{array}{c}\text { Vent to } \\
\text { Filters } \\
\text { and } \\
\text { Stack }\end{array}$ & $\begin{array}{l}\text { Reactor } \\
\text { Product }\end{array}$ & $\begin{array}{l}\text { Slaked } \\
\text { Lime } \\
\text { Slurry }\end{array}$ & Filtrate & $\begin{array}{r}\text { Molst } \\
\text { Cake }\end{array}$ & $\begin{array}{l}\text { Moisture } \\
\text { To Vent }\end{array}$ & $\begin{array}{c}\text { Dried } \\
\text { Product }\end{array}$ & $\begin{array}{l}\text { lime To } \\
\text { Slaker }\end{array}$ & $\begin{array}{l}\text { Water To } \\
\text { Slaker }\end{array}$ & $\begin{array}{l}\text { Makeup } \\
\text { Water }\end{array}$ & To Disposal \\
\hline Stream No. & 501 & 504 & 505 & 508 & 509 & 510 & 511 & 512 & 513 & 514 & 515 & 516 \\
\hline Type of flow & $\begin{array}{l}\text { Semi- } \\
\text { Cont. }\end{array}$ & Cont. & Cont. & Cont. & Cont. & Cont. & Cont. & Cont. & Cont. & Cont. & Cont. & Batch \\
\hline Avg operating $h / d^{(a)}$ & 24 & 24 & 24 & 24 & 24 & 24 & 24 & 24 & 24 & 24 & 24 & 24 \\
\hline Avg gas flow, slpd $/ 1000^{(b)}$ & 8623.9 & 482.3 & Negl & & & & & & & & & \\
\hline Avg slurry/solids flow, $\mathrm{kg} / \mathrm{d}$ & & & 270.994 & 254,531 & & 65,490 & & 39,607 & 22,744 & 231,787 & & 39,607 \\
\hline Avg flufd flow $\mathrm{kg} / \mathrm{d}$ (c) & & & & & 205,504 & & 25,883 & & & & & \\
\hline Heat load, $w / 1$ or $w / \mathrm{kg}^{(c)}$ & TBD & TBD & TBD & & & TBD & Neg1 & TBD & & & & TBD \\
\hline Activity, Ci/l or $\mathrm{Ci} / \mathrm{kg}^{(\mathrm{d})}$ & $2.92(-5)$ & $5.27(-4)$ & TBD & & & TBD & Neg1 & TBD & & & & $\mathrm{TBD}$ \\
\hline $0_{2}$, slpd $/ 1000$ & 120.7 & 120.7 & NegI & & & & & & & & & \\
\hline $\mathrm{CO}_{2}$, slpd $/ 1000$ & 8468.3 & 84.7 & Neg1 & & & & & & & & & \\
\hline $\mathrm{co}, \mathrm{sipd} / 1000$ & 27.8 & 27.8 & Negl 1 & & & & & & & & & \\
\hline $\mathrm{N}_{2}, \mathrm{~s} 1 \mathrm{pd} / 1000$ & 363.3 & 363.3 & Negl 1 & & & & & & & & & \\
\hline Krypton, slpd/1000 & $1.05(-3)$ & $1.05(-3)$ & NegI & & & & & & & & & \\
\hline Xenon, slpd/1000 & $5.96(-3)$ & $5.96(-3)$ & Neg1 & & & & & & & & & \\
\hline No $x$, slpd $/ 1000$ & $8.2(-2)$ & $4 \cdot 1(-2)$ & Negl & & & & & & & & & \\
\hline $\mathrm{NH}_{3}$, slpd/1000 & $8.2(-2)$ & $8.2(-2)$ & Neg 1 & & & & & & & & & \\
\hline Sulfur, $\mathrm{kg} / \mathrm{d}$ & $\mathrm{TBD}$ & TBD & TBD & & & TBD & & TBD & & & & TBD \\
\hline Carbon- $14, \mathrm{~kg} / \mathrm{d}$ & $1.6(-6)$ & $1.6(-8)$ & $1.6(-6)$ & & & $1.6(-6)$ & & $1.6(-6)$ & & & & $1.6(-6)$ \\
\hline Radon, $\mathrm{kg} / \mathrm{d}$ & $T B D$ & $T B D$ & $T B D$ & & & TBD & & TBD & & & & TBD \\
\hline $\mathrm{Tritifm}, \mathrm{kg} / \mathrm{d}$ & $T B D$ & $T B D$ & $T B D$ & & & $T B D$ & & TBD & & & & TBD \\
\hline Krypton, $\mathrm{kg} / \mathrm{d}$ & $4.6(-7)$ & $4.6(-7)$ & Neg1 & & & Neg1 & & Negl & & & & Neg1 \\
\hline Xenon, $\mathrm{kg} / \mathrm{d}$ & $4.0(-6)$ & $4.0(-6)$ & Negl 1 & & & Negl & & Neg 1 & & & & Neg1 \\
\hline Iodine, $\mathrm{kg} / \mathrm{d}$ & TBD & $T B D$ & $T B D$ & & & TBD & & TBD & & & & TBD \\
\hline other $\mathrm{FP}, \mathrm{kg} / \mathrm{d}$ & TBD & $T B D$ & TBD & & & $T B D$ & & TBD & & & & TBD \\
\hline $\begin{array}{l}\text { Other particulates or } \\
\text { contaminants, kg/d } \\
\mathrm{CaO}, \mathrm{kg} / \mathrm{d}\end{array}$ & $\mathrm{TBD}$ & $T B D$ & 682 & 682 & & 682 & & 682 & $\begin{array}{l}682 \\
22,062\end{array}$ & & & 682 \\
\hline $\mathrm{H}_{2} \mathrm{O}, \mathrm{kg} / \mathrm{d}$ & & 4.8 & 230,037 & 223,305 & 204,114 & 25,923 & 25,883 & 40 & & 230,396 & 26,282 & 40 \\
\hline $\mathrm{Ca}(\mathrm{OH})_{2}, \mathrm{~kg} / \mathrm{d}$ & & & 2,848 & 30.544 & 1,390 & 1,458 & & 1.458 & & 1,391 & & $\cdot, 458$ \\
\hline $\mathrm{CaCO}_{3}, \mathrm{~kg} / \mathrm{d}$ & & & 37,427 & & TBD & 37,427 & & 37,427 & & & & .42 \\
\hline
\end{tabular}

(a) Exclustive of rework. Based on 233 equivalent operating days/yr.

(b) Exclusive of filter blowback and bed regeneration $\mathrm{CO}_{2}$ additions. Not fncluding insol dryers air contribution.

(c) Decay heat only (excludes process heating and cooling). Excludes contribution of any "TBD" products.

(d) Excludes contribution of any "TBD" products.

ASSUMPTIONS :

1. $99 \% \mathrm{CO}_{2}$ remova1.

2. $5 \% \mathrm{Ca}(\mathrm{OH})_{2}$ (unreacted) in the product.

3. $40 \% \mathrm{H}_{2} \mathrm{O}$ in filter cake.

4. $3 \%$ solid impurity in $\mathrm{CaO}$

5. 0.1 wt \% moisture in product. 
TABLE B-8
MATERIAL BALANCE FOR THOREX SOLVENT EXTRACTION PF-320-

\begin{tabular}{|c|c|c|c|c|c|c|c|c|c|c|c|c|c|c|c|c|c|c|c|c|}
\hline & $\begin{array}{l}\text { From } \\
\text { Fertile } \\
\text { Account- } \\
\text { ability }\end{array}$ & $\begin{array}{c}\text { From } \\
\text { Waste } \\
\text { Recovery }\end{array}$ & $\begin{array}{c}\mathrm{H}_{2} \mathrm{O} \\
\text { Addition }\end{array}$ & To HLW & $\begin{array}{c}\text { Formic } \\
\text { Acid } \\
\text { Addition }\end{array}$ & \begin{tabular}{|} 
Demin. \\
Water \\
Addition
\end{tabular} & $\begin{array}{l}\text { Denitrator } \\
\text { Product }\end{array}$ & \begin{tabular}{|l} 
From \\
Waste \\
Rework
\end{tabular} & $\begin{array}{l}\text { Cold } \\
\text { Chem } \\
\text { Add }\end{array}$ & $\begin{array}{c}1 \mathrm{~A} \\
\text { Column } \\
\text { Feed }\end{array}$ & $\begin{array}{c}\text { Di1ute } \\
\text { Acid }\end{array}$ & ${ }_{\mathrm{AC}}^{1} \frac{\mathrm{M}}{\mathrm{i} d}$ & $\begin{array}{l}\text { Waste } \\
\text { Recovery } \\
\text { Product }\end{array}$ & $\begin{array}{l}\text { Conc. } \\
\text { Acid }\end{array}$ & $\begin{array}{c}\text { Solvent } \\
\text { From No. } \\
\text { Treat. }\end{array}$ & $\begin{array}{c}\text { Aqueous } \\
\text { Waste }\end{array}$ & $\begin{array}{c}\text { Waste } \\
\text { Solvent }\end{array}$ & $\begin{array}{r}\text { High } \\
\text { Level } \\
\text { Waste }\end{array}$ & $\begin{array}{c}1 \mathrm{~A} \\
\text { Column } \\
\text { Product }\end{array}$ & $\begin{array}{c}\text { To } \\
\text { Vessel } \\
\text { Of } f-\text { Gas }\end{array}$ \\
\hline $\begin{array}{l}\text { Stream name } \\
\text { Stream No. }\end{array}$ & 100 & 101 & 103 & $\begin{array}{c}\mathrm{AD} \\
104\end{array}$ & 105 & 134 & 106 & 109 & $110-112$ & \begin{tabular}{|l|}
$\mathrm{AF}$ \\
114
\end{tabular} & $\begin{array}{l}\text { 1AIS } \\
115\end{array}$ & $\begin{array}{l}\text { 1AS } \\
116\end{array}$ & $\begin{array}{l}\text { WRP } \\
117\end{array}$ & $\begin{array}{l}1 \mathrm{AA} \\
118\end{array}$ & $\begin{array}{c}\mathrm{AX} \\
119\end{array}$ & $\begin{array}{l}1 \mathrm{AW} \\
120\end{array}$ & 121 & $\begin{array}{l}1 \mathrm{AW} \\
122\end{array}$ & $\begin{array}{c}1 \mathrm{AP} \\
124\end{array}$ & 133 \\
\hline Relative flow rate & 162.5 & & 325 & 411 & 23.6 & & 100 & & & 100 & 25 & 125 & 225 & 33.3 & 1192 & 283.3 & & 283.3 & 1417 & \\
\hline Avg flow, $1 / \mathrm{d}(\mathrm{a}, \mathrm{b})$ & 561.3 & TBD & 1122.6 & 1420 & 81.4 & TBD & 345.5 & TBD & TBD & 345.5 & 86.4 & 431.9 & 777.4 & 115.2 & 4118 & 979 & TBD & 979 & 4895 & TBD \\
\hline Oper. flow rate, $1 / \mathrm{hr}^{(\mathrm{b})}$ & 23.4 & & 46.8 & 59.2 & 3.4 & & 14.4 & & & 14.4 & 3.6 & 18.0 & 32.4 & 4.8 & 171.6 & 40.8 & & 40.8 & 204 & \\
\hline Design flow rate, $1 / \mathrm{hr}^{(b)}$ & 47.0 & & 94.0 & 118.5 & 6.8 & & 29.0 & & & 29.0 & 7.5 & 36.5 & 65.5 & 9.7 & 344 & 82 & & 82 & 410 & \\
\hline Heat load, $W / 1^{(c)}$ & TBD & & & & & & TBD & & & TBD & & & TBD & & & TBD & & TBD & TBD & TBD \\
\hline Activity, Ci/1 & TBD & & & TBD & & & TBD & & & TBD & & & TBD & & & TBD & & TBD & TBD & TBD \\
\hline Carbon, g/1 & 0.05 & & & & & & 0.08 & & & 0.08 & & & & & & 0.03 & & 0.03 & & \\
\hline Uranium, $g / 1$ & 9.7 & & & & & & 15.8 & & & 15.8 & & & Trace & & & Trace & & Trace & 1.1 & \\
\hline Thorium, g/1 & 214.2 & & & & & & 348.2 & & & 348.2 & & & Trace & & & 0.1 & & 0.1 & 24.6 & \\
\hline $\mathrm{Pu}, \mathrm{g} / 1$ & 0.002 & & & & & & 0.003 & & & 0.003 & & & & & & Trace & & Trace & Trace & \\
\hline Other н.М., g/1 & 0.03 & & & & & & 0.05 & & & 0.05 & & & Trace & & & 0.02 & & 0.02 & Trace & \\
\hline Fission products, g/1 & 12.5 & & & 0.025 & & & 20.2 & & & 20.2 & & & Trace & & & 7.2 & & 7.2 & Trace & TBD \\
\hline $\mathrm{HNO}_{3}, \underline{\mathrm{M}}$ & 7.9 & & & 2.88 & & & 1.0 & & & 1.0 & 0.01 & 1.0 & 0.15 & 13.0 & & 2.3 & Trace & 2.3 & 0.15 & \\
\hline $\mathrm{F}^{-}, \underline{\mathrm{M}}$ & 0.05 & & & 0.0006 & & & 0.075 & & & 0.075 & & & & & & 0.03 & & 0.03 & & \\
\hline $\mathrm{Al}^{+\bar{\Gamma}}, \mathrm{M}$ & 0.1 & & & & & & 0.15 & & & 0.15 & & & & & & 0.06 & & 0.06 & & \\
\hline $\mathrm{Cd}^{++}, \underline{\mathrm{M}}$ & 0.075 & & & & & & 0.12 & & & 0.12 & & & & & & 0.04 & & 0.04 & & \\
\hline $\mathrm{HCOOH}, \underline{M}$ & & & & 1.3 & 23.0 & & & & & & & & & & & & & & & \\
\hline TBP-NPH, $V / 0$ TBP & & & & & & & & & & & & & 30 & & 30 & & & & 30 & \\
\hline $\begin{array}{ll}\mathrm{NO}_{\mathrm{x}} & (\mathrm{s} 1 \mathrm{pd}) \\
\mathrm{H}_{2} \mathrm{O} & (\mathrm{s} 1 \mathrm{pd})\end{array}$ & & & & 1.2 & & & & & & & & & & & & & & & & \\
\hline
\end{tabular}

(a) Exclusive of rework. Based on 263 equivalent operating days/yr.

(b) Based on processing 10,000 fuel elements/yr. Design f1ow rate is $20,000 \mathrm{FE} / \mathrm{yr}$ exclusive of excess required for rework.

(c) Decay heat only. 
TABLE B-9

MATERIAL BALANCE FOR THOREX SOLVENT EXTRACTION PF-320-2

\begin{tabular}{|c|c|c|c|c|c|c|c|c|c|c|c|c|c|}
\hline & $\begin{array}{l}1 \mathrm{BX} \\
\text { Feed }\end{array}$ & $\begin{array}{l}\text { Dilute } \\
\text { Acid } \\
\text { Addition }\end{array}$ & $\begin{array}{l}1 \mathrm{BX} \\
\text { Uran1um } \\
\text { Product }\end{array}$ & $\begin{array}{l}1 \mathrm{BX} \\
\text { Thor 1um } \\
\text { Product }\end{array}$ & $\begin{array}{c}\text { Solvent } \\
\text { From No. } 1 \\
\text { Treat. }\end{array}$ & $\begin{array}{l}\text { Return } \\
\text { To } \\
\text { 1A }\end{array}$ & $\begin{array}{l}\text { 1BS } \\
\text { Thor1um } \\
\text { Product }\end{array}$ & $\begin{array}{c}\text { Dilute } \\
\text { Acid } \\
\text { Addition }\end{array}$ & $\begin{array}{c}\text { 1C } \\
\text { Uranzum } \\
\text { Product }\end{array}$ & $\begin{array}{c}\text { Nitric } \\
\text { Acid } \\
\text { Addition }\end{array}$ & $\begin{array}{c}2 \mathrm{~A} \\
\text { Feed }\end{array}$ & $\begin{array}{c}\text { To } \\
\text { Solvent } \\
\text { Recovery }\end{array}$ & $\begin{array}{c}\text { To } \\
\text { Vessel } \\
\text { of } f-\text { Gas }\end{array}$ \\
\hline Stream name & TAP & $1 \mathrm{BX}$ & $1 \mathrm{BU}$ & $1 \mathrm{BXT}$ & 1BS & $1 \mathrm{BSU}$ & IBT & $1 c x$ & $1 \mathrm{CU}$ & & $\mathrm{ICU}$ & $1 \mathrm{CW}$ & \\
\hline Stream No. & 200 & 202 & 203 & 204 & 206 & 207 & 208 & 213 & 215 & 216 & 217 & 214 & 226 \\
\hline Relative flow rate & 1417 & 850 & 1700 & 850 & 283.3 & 283.3 & 850 & 708 & 708 & 208 & 916 & 1700 & \\
\hline Average flow, $1 / d^{(a)}$ & 4895 & 2937 & 5874 & 2937 & 979 & 979 & 2937 & 2446 & 2446 & 720 & 3166 & 5874 & TBD \\
\hline Oper flow rate, $1 / \mathrm{h}^{(\mathrm{b})}$ & 204 & 122.4 & 244.8 & 122.4 & 40.8 & 40.8 & 122.4 & 102 & 102 & 30 & 132 & 244.8 & \\
\hline Design flow rate, $1 / h^{(b)}$ & 410 & 245 & 492 & 245 & 82 & 82 & 245 & 205 & 205 & 60 & 265 & 492 & \\
\hline Heat load, W/, (c) & $\mathrm{rBD}$ & & $\mathrm{TBD}$ & $T B D$ & & & TBD & & $\mathrm{TBD}$ & & TBD & TBD & \\
\hline Activity, $C_{1} / 1$ & TBD & & TBD & TBD & & & $\mathrm{TBD}$ & & TBD & & TBD & TBD & \\
\hline Uranium, $g / 1$ & 1.1 & & 0.92 & 0.12 & & 0.35 & 0.001 & & 2.2 & & 1.7 & 0.001 & \\
\hline Thorium, $g / 1$ & 24.6 & & 0.002 & 41 & & & 41 & & 0.005 & & 0.004 & 0.002 & \\
\hline $\mathrm{Pu}, \mathrm{g} / 1$ & Trace & & Trace & 0.0004 & & & 0.0004 & & Trace & & Trace & Trace & \\
\hline Other H.M., $\mathrm{g} / 1$ & Trace & & & Trace & & & Trace & & Trace & & Trace & Trace & \\
\hline Fission products, $g / 1$ & Trace & & Neg1. & 0.0002 & & & 0.0002 & & Trace & & 0.0002 & Trace & \\
\hline $\mathrm{HNO}_{3}, \underline{\mathrm{M}}$ & 0.15 & 0.2 & 0.02 & 0.44 & & 0.10 & 0.41 & 0.01 & 0.058 & 13.0 & 3.0 & Trace & \\
\hline$F^{-}, \underline{M}$ & & 0.005 & & 0.005 & & & 0.005 & & & & & & \\
\hline TBP-NPH, \% TBP & 30 & & 30 & & 30 & & Trace & & & & & 30 & \\
\hline $\mathrm{Fe}^{++}, \underline{M}$ & & 0.0006 & & 0.0006 & & & 0.0006 & & & & & & \\
\hline $\mathrm{N}_{2} \mathrm{H}_{4}, \mathrm{M}$ & & 0.005 & & 0.005 & & & 0.005 & & & & & & \\
\hline
\end{tabular}

(a) Exclusive of rework. Based on 263 equivalent operating days/yr.

(b) Based on processing 10,000 fuel elements/vr. Design flow rate is $20,000 \mathrm{FE} / \mathrm{yr}$ exclusive of excess required for rework.

(c) Decay heat only. 
TABLE B-10

MATERIAL BALANCE FOR THOREX SOLVENT EXTRACTION PF-320-3

\begin{tabular}{|c|c|c|c|c|c|c|c|c|c|c|c|c|}
\hline & $\begin{array}{c}2 \mathrm{~A} \\
\text { Feed }\end{array}$ & $\begin{array}{l}\text { Dilute } \\
\text { Acid } \\
\text { Addition }\end{array}$ & $\begin{array}{l}\text { Solvent } \\
\text { From No. } 2 \\
\text { Treat. }\end{array}$ & $\begin{array}{c}2 \mathrm{~A} \\
\text { Waste }\end{array}$ & $\begin{array}{c}2 \mathrm{~A} \\
\text { Uranium } \\
\text { Product }\end{array}$ & $\begin{array}{c}2 \mathrm{~B} \\
\text { Feed }\end{array}$ & $\begin{array}{c}\text { Dilute } \\
\text { Acid } \\
\text { Addition }\end{array}$ & $\begin{array}{c}2 \mathrm{~B} \\
\text { Uranium } \\
\text { Product }\end{array}$ & $\begin{array}{l}\quad \text { To } \\
\text { Solvent } \\
\text { Recovery }\end{array}$ & $\begin{array}{c}\text { Nitric } \\
\text { Acid } \\
\text { Addition }\end{array}$ & $\begin{array}{c}3 \mathrm{~A} \\
\text { Feed }\end{array}$ & $\begin{array}{c}\text { To } \\
\text { Vessel } \\
\text { Off-Gas }\end{array}$ \\
\hline Stream name & $2 \mathrm{AF}$ & $2 \mathrm{AS}$ & $2 \mathrm{AX}$ & $2 \mathrm{AW}$ & $2 \mathrm{AU}$ & 2BF & $2 \mathrm{BX}$ & $2 \mathrm{BU}$ & $2 \mathrm{BW}$ & & $2 \mathrm{BU}$ & \\
\hline Stream No. & 302 & 303 & 304 & 306 & 305 & 312 & 313 & 315 & 314 & 316 & 317 & 325 \\
\hline Relative flow rate & 916 & 100 & 254 & 1016 & 254 & 254 & 170 & 170 & 254 & 50 & 220 & \\
\hline Average flow, $1 / d^{(a)}$ & 3166 & 346 & 878 & 3512 & 878 & 878 & 587 & 587 & 878 & 171 & 758 & TBD \\
\hline Oper. flow rate, $1 / h^{(b)}$ & 132 & 14.4 & 36.6 & 146.4 & 36.6 & 36.6 & 24.5 & 24.5 & 36.6 & 7.1 & 31.6 & \\
\hline Design flow rate, $1 / h^{(b)}$ & 265 & 29 & 74 & 284 & 74 & 74 & 49 & 49 & 74 & 14.3 & 63.3 & \\
\hline Heat load, $w / 1^{(c)}$ & TBD & & & & TBD & TBD & & TBD & IBD & & $\mathrm{TBD}$ & \\
\hline Activity, Ci/1 & TBD & & & & TBD & TBD & & TBD & TBD & & TBD & \\
\hline Uranium, $g / 1$ & 1.7 & & & 0.0015 & 6.1 & 6.1 & & 9.1 & 0.006 & & 7.05 & \\
\hline Thorium, $\mathrm{g} / 1$ & 0.004 & & & Trace & 0.0015 & 0.0015 & & Trace & Trace & & Trace & \\
\hline $\mathrm{Pu}, \mathrm{g} / 1$ & Trace & & & Trace & & & & & & & & \\
\hline Other H.M., g/1 & Trace & & & & & & & & & & & \\
\hline Fission products, $\mathrm{g} / \mathrm{l}$ & 0.0002 & & & Trace & Trace & Trace & & Trace & Trace & & Trace & \\
\hline $\begin{array}{l}\mathrm{HNO}_{3}, \underline{\mathrm{M}} \\
\mathrm{F}^{-}, \mathrm{M}\end{array}$ & 3.0 & 0.3 & & 2.72 & 0.05 & 0.05 & 0.01 & 0.085 & Trace & 13.0 & 3.0 & \\
\hline TBP-NPH, \% TBP & & & 30 & & 30 & 30 & & & 30 & & & \\
\hline $\mathrm{Fe}^{H}, \underline{M}$ & & 0.005 & & 0.0005 & & & & & & & & \\
\hline $\mathrm{N}_{2} \mathrm{H}_{4}, \underline{\mathrm{M}}$ & & 0.005 & & 0.0005 & & & & & & & & \\
\hline
\end{tabular}

(a) Exclusive of rework. Based on 263 equivalent operating days/yr.

(b) Based on processing 10,000 fuel elements/yr. Design flow rate is $20,000 \mathrm{FE} / \mathrm{yr}$ exclusive of excess required for rework.

(c) Decay heat only. 
TABLE B-11

MATERIAL BALANCE FOR THOREX SOLVENT EXTRACTION PF-320-4

\begin{tabular}{|c|c|c|c|c|c|c|c|c|c|c|c|c|c|c|}
\hline & $\begin{array}{r}3 \mathrm{~A} \\
\text { Feed } \\
\end{array}$ & $\begin{array}{c}\text { Dilute } \\
\text { Aczd }\end{array}$ & $1 \stackrel{\mathrm{M}}{\mathrm{AcId}}$ & $\begin{array}{c}\text { Solvent } \\
\text { From No. } 2 \\
\text { Treat. } \\
\end{array}$ & $\begin{array}{l}\text { To Low } \\
\text { Level } \\
\text { Waste }\end{array}$ & $\begin{array}{c}3 \mathrm{~A} \\
\text { Uranium } \\
\text { Product }\end{array}$ & $\begin{array}{c}3 B \\
\text { Feed } \\
\end{array}$ & $\begin{array}{l}\text { Dilute } \\
\text { Aced }\end{array}$ & $\begin{array}{c}\text { To } \\
\text { Solvent } \\
\text { Recovery }\end{array}$ & $\begin{array}{c}3 \mathrm{~B} \\
\text { Uranium } \\
\text { Product }\end{array}$ & \begin{tabular}{|l} 
Solvent \\
Addition
\end{tabular} & $\begin{array}{c}\text { Wash } \\
\text { Rework }\end{array}$ & $\begin{array}{c}\text { Conc. } \\
\text { Feed }\end{array}$ & $\begin{array}{c}\text { To } \\
\text { Vessel } \\
\text { Off-Gas }\end{array}$ \\
\hline Stream name & $3 \mathrm{AF}$ & 3AIS & $3 A S$ & $3 \mathrm{AX}$ & 3AW & $3 \mathrm{AU}$ & $3 \mathrm{BF}$ & $3 \mathrm{~B} \lambda$ & $3 \mathrm{BW}$ & $3 \mathrm{BU}$ & 3 WS & $3 \mathrm{wW}$ & 3BU & \\
\hline Stream No. & 402 & 403 & 404 & 405 & 406 & 408 & 409 & 410 & 411 & 412 & 415 & 416 & 419 & 428 \\
\hline Relative flow rate & 220 & 20 & 5 & 65 & 245 & 65 & 66 & 51 & 66 & 51 & 0.3 & 0.3 & 51 & \\
\hline Average $\mathrm{flow}, 1 / \mathrm{d}^{(\mathrm{a})}$ & 758 & 68.3 & 17.1 & 224 & 844 & 224 & 225 & 174 & 225 & 174 & 1.0 & 1.0 & 174 & TBD \\
\hline Oper. flow rate, $1 / h^{(b)}$ & 31.6 & 2.85 & 0.7 & 9.3 & 35.2 & 9.3 & 9.4 & 7.25 & 9.4 & 7.25 & 0.04 & 0.04 & 7.25 & \\
\hline Design flow rate, $1 / h^{(b)}$ & 63.3 & 5.7 & 1.45 & 18.7 & 70.5 & 18.7 & 18.8 & 14.5 & 18.8 & 14.5 & 0.1 & 0.1 & 14.5 & \\
\hline Heat loas $w / 1^{(c)}$ & TBD & & & & Neg1 & TBD & TBD & & Neg1 & TBD & & & $\mathrm{TBD}$ & \\
\hline Activity, $\mathrm{C}_{1} / 1$ & TBD & & & & TBD & TBD & TBD & & TBD & $T B D$ & & & TBD & \\
\hline Uranium, $g / 1$ & 7.05 & & & & 0.005 & 23.8 & 23.7 & & 0.024 & 30.6 & & Trace & 30.6 & \\
\hline Thor 1 um, $g / 1$ & Trace & & & & Trace & Neg1 & Neg1 & & $\mathrm{Neg} 1$ & Neg1 1 & & & Negl & \\
\hline $\mathrm{Pu}, \mathrm{g} / \mathrm{I}$ & & & & & & & & & & & & & & \\
\hline Other H.M., $\mathrm{g} / 1$ & & & & & Trace & & & & & & & & & \\
\hline Fission product, $g / 1$ & Trace & & & & Trace & Neg1 & Neg1 & & & Neg1 & & & Neg1 & \\
\hline $\mathrm{HNO}_{3}, \underline{\mathrm{M}}$ & 3.0 & 0.1 & 1.0 & & 2.71 & 0.03 & 0.03 & 0.01 & Trace & 0.049 & & Trace & 0.049 & \\
\hline $\mathrm{F}^{-}, \underline{\mathrm{M}}$ & & & & & & & & & & & & & & \\
\hline TBP, \% & & & & 30 & & 30 & 30 & & 30 & & & Trace & & \\
\hline $\mathrm{NPH}, \%$ & & & & 70 & & 70 & 70 & & 70 & & 100 & 100 & & \\
\hline
\end{tabular}

(a) Exclusive of rework. Based on 263 equivalent operating days/yr.

(b) Based on processing 10,000 fuel elements/yr. Design flow rate is $20,000 \mathrm{FE} / \mathrm{yr}$ exclusive of excess required for rework.

(c) Decay heat only. 
TABLE B-12

MATERIAL BALANCE FOR THOREX SOLVENT EXTRACTION PF-320-5

\begin{tabular}{|c|c|c|c|c|c|}
\hline & $\begin{array}{l}\text { Conc. } \\
\text { Feed }\end{array}$ & $\begin{array}{l}\text { Conc. } \\
\text { Over- } \\
\text { Heads }\end{array}$ & $\begin{array}{l}\text { Conc. } \\
\text { Uranium } \\
\text { Product }\end{array}$ & $\begin{array}{c}\text { Product } \\
\text { to } \\
\text { Refab }\end{array}$ & $\begin{array}{c}\text { To } \\
\text { Vessel } \\
\text { Of } \mathrm{f}-\mathrm{Gas}\end{array}$ \\
\hline Stream name & $3 \mathrm{BU}$ & & $3 \mathrm{UC}$ & $3 \mathrm{UC}$ & \\
\hline Stream No. & 500 & 504 & 503 & 510 & 517 \\
\hline Relative flow rate & 51 & 46 & 5 & 5 & \\
\hline Average flow, $1 / d^{(a)}$ & 174 & 157 & 17 & 17 & TBD \\
\hline Operating flow rate, $1 / h^{(b)}$ & 7.25 & 6.5 & 0.7 & 0.7 & \\
\hline Design flow rate, $1 / h^{(b)}$ & 14.5 & 13.1 & 1.4 & 1.4 & \\
\hline Heat load, $w / 1{ }^{(c)}$ & TBD & & $\mathrm{TBD}$ & TBD & \\
\hline Activity, Ci/1 & $\mathrm{TBD}$ & & TBD & TBD & \\
\hline Uranium, $g / 1$ & 30.6 & & 313 & 313 & \\
\hline Thorium, g/1 & Neg 1 & & Neg1 & Neg 1 & \\
\hline Fission products, $\mathrm{g} / 1$ & Neg 1 & & Neg 1 & Negl & \\
\hline $\mathrm{HNO}_{3}, \underline{\mathrm{M}}$ & 0.049 & 0.02 & 0.32 & 0.32 & \\
\hline
\end{tabular}

(a) Exclusive of rework. Based on 263 equivalent operating days/yr.

(b) Based on processing 10,000 fuel elements/yr. Design flow rate is $20,000 \mathrm{FE} / \mathrm{yr}$ exclusive of excess required for rework.

(c) Decay heat only. 
TABLE B-13

MATERIAL BALANCE FOR THOREX SOLVENT EXTRACTION PF-350-1

\begin{tabular}{|c|c|c|c|c|c|c|c|c|c|c|c|c|c|}
\hline & $\begin{array}{l}\text { IBT } \\
\text { Conc. } \\
\text { Feed }\end{array}$ & $\begin{array}{l}\text { Conc. } \\
\text { Over- } \\
\text { Heads }\end{array}$ & $\begin{array}{l}\text { Conc. } \\
\text { Prod. }\end{array}$ & $\begin{array}{c}2 \mathrm{D} \\
\text { Denit. } \\
\text { Feed }\end{array}$ & Ste & m Add & $\begin{array}{l}\text { Formic } \\
\text { Acid } \\
\text { Add }\end{array}$ & $\begin{array}{l}\text { To } \\
\text { HLW }\end{array}$ & $\begin{array}{l}\text { Denit. } \\
\text { Prod. }\end{array}$ & $\begin{array}{l}\text { Demin. } \\
\text { Water }\end{array}$ & $\begin{array}{l}\text { Feed } \\
\text { Adj. }\end{array}$ & $\begin{array}{l}\text { 2D } \\
\text { Feed }\end{array}$ & $\begin{array}{l}\text { To } \\
\text { Vessel } \\
\text { Off-Gas }\end{array}$ \\
\hline $\begin{array}{l}\text { Stream name } \\
\text { Stream No. }\end{array}$ & $\begin{array}{l}1 \mathrm{BT} \\
101\end{array}$ & 103 & 102 & 105 & 104 & 106 & 107 & 111 & 108 & 109 & $113-114$ & $\begin{array}{l}2 \mathrm{DF} \\
117\end{array}$ & 125 \\
\hline $\begin{array}{l}\text { Relative flow rate } \\
\text { Average flow, } 1 / d^{(a)} \\
\text { Oper. flow rate, } 1 / h^{(b)} \\
\text { Design flow rate, } 1 / h^{(b)} \\
\text { Heat load, W/1 } \\
\text { Activity, Ci/1 } \\
\text { Uranium, g/1 } \\
\text { Thorium, g/1 } \\
\text { Pu, g/1 } \\
\text { Other H.M., g/1 } \\
\text { Fission products, g/1 } \\
\text { HNO } 3, \underline{M} \\
F^{-}, \underline{M} \\
\text { HCOOH, }^{M} \\
\text { TBP-NPH, V\% TBP } \\
\text { Fe }^{++}, \underline{M} \\
N_{2} H_{4}, M\end{array}$ & $\begin{array}{c}850 \\
2937 \\
122.4 \\
245 \\
\text { TBD } \\
\text { TBD } \\
0.002 \\
41.0 \\
0.0004 \\
\text { Trace } \\
0.0002 \\
0.39 \\
0.005 \\
\text { Trace } \\
0.0006 \\
0.005\end{array}$ & (1) & $\begin{array}{c}850 \\
2937 \\
122.4 \\
245 \\
\text { TBD } \\
\text { TBD } \\
0.002 \\
41.0 \\
0.0004 \\
\text { Trace } \\
0.0002 \\
0.39 \\
0.005 \\
\\
0.0006 \\
0.005\end{array}$ & $\begin{array}{c}850 \\
2937 \\
122.4 \\
245 \\
\text { TBD } \\
\text { TBD } \\
0.002 \\
41.0 \\
0.0004 \\
\text { Trace } \\
0.0002 \\
0.39 \\
0.005 \\
\\
0.0006 \\
0.005\end{array}$ & TBD & $\begin{array}{l}1275 \\
4406 \\
183.6 \\
367.1\end{array}$ & $\begin{array}{r}29.8 \\
102.8 \\
4.3 \\
8.6\end{array}$ & $\begin{array}{c}2115 \\
7298 \\
304 \\
608 \\
\text { TBD } \\
\text { TBD } \\
\\
\\
\text { Trace } \\
\text { Trace } \\
0.32\end{array}$ & $\begin{array}{c}39.4 \\
148.3 \\
6.2 \\
12.4 \\
\text { TBD } \\
\text { TBD } \\
0.04 \\
812 \\
0.008 \\
\text { Trace } \\
0.004 \\
-0.35 \\
0.1\end{array}$ & $\begin{array}{c}110.6 \\
370.7 \\
15.4 \\
30.9 \\
\text { TBD } \\
\text { TBD }\end{array}$ & TBD & $\begin{array}{c}150 \\
519 \\
21.6 \\
43.3 \\
\text { TBD } \\
\text { TBD } \\
0.01 \\
232 \\
0.002 \\
\text { Trace } \\
0.001 \\
-0.1 \\
0.03 \\
\\
0.0035 \\
0.03\end{array}$ & TBD \\
\hline
\end{tabular}

(a) Exclusive of rework. Based on 263 equivalent operating days/yr.

(b) Based on processing 10,000 fuel elements/yr. Design flow rate is $20,000 \mathrm{FE} / \mathrm{yr}$ exclusive of excess required for rework.

(c) Decay heat only. 
TABLE B-14
MATERIAL BALANCE FOR THOREX SOLVENT EXTRACTION PF-350-2

\begin{tabular}{|c|c|c|c|c|c|c|c|c|c|c|c|c|c|c|c|c|c|c|}
\hline & $\underset{\text { Feed }}{2 \mathrm{D}}$ & $\begin{array}{l}\text { D1lute } \\
\text { Ac1d }\end{array}$ & $\stackrel{5}{\frac{M}{M}}$ & $\begin{array}{l}\text { Solvent } \\
\text { From No. } 2 \\
\text { Treat. }\end{array}$ & $\begin{array}{l}\text { Conc. } \\
\text { Acld }\end{array}$ & $\begin{array}{l}2 \mathrm{D} \\
\text { Product }\end{array}$ & $\begin{array}{c}2 \mathrm{D} \\
\text { Waste }\end{array}$ & $\begin{array}{l}\text { To } \\
\text { HLW }\end{array}$ & $\begin{array}{c}2 E \\
\text { Feed }\end{array}$ & $\begin{array}{c}2 E \\
\text { Product }\end{array}$ & $\begin{array}{c}2 \mathrm{E} \\
\text { Waste }\end{array}$ & Dilute & $\begin{array}{c}2 \mathrm{ET} \\
\text { Concen. } \\
\text { Feed }\end{array}$ & $\begin{array}{l}\text { Conc. } \\
\text { Over- } \\
\text { heads }\end{array}$ & $\begin{array}{c}\text { 2ET } \\
\text { Product }\end{array}$ & $\begin{array}{l}\text { To } \\
\text { Th } \\
\text { Store }\end{array}$ & $\begin{array}{c}\text { To } \\
\text { Vesse1 } \\
\text { Off-Gas }\end{array}$ & $\begin{array}{c}2 E \\
\text { Scrub }\end{array}$ \\
\hline Stream name & $2 \mathrm{DF}$ & $2 \mathrm{DS}$ & $2 \mathrm{DIS}$ & $2 \mathrm{DX}$ & $2 \mathrm{DA}$ & $2 \mathrm{DT}$ & $2 \mathrm{DW}$ & & $2 \mathrm{EF}$ & $2 \mathrm{ET}$ & 2EW & $2 \mathrm{EX}$ & $2 \mathrm{ET}$ & & $2 \mathrm{THN}$ & 2 2THN & & $2 \mathrm{ES}$ \\
\hline Stream No. & 200 & 202 & 201 & 203 & 236 & 204 & 205 & 208 & 210 & 213 & 212 & 211 & 216 & 219 & 218 & 223 & 235 & 237 \\
\hline Relative flow rate & 150 & 125 & 25 & 1159 & 25 & 1159 & 325 & 325 & 1159 & 680 & 1301 & 680 & 680 & 605 & 75 & 75 & & 142 \\
\hline Average flow, $1 / d^{(a)}$ & 519 & 432.5 & 86.5 & 4010 & 86.5 & 4010 & 1124.5 & 1124.5 & 4010 & 2352 & 4501 & 2352 & 2352 & 2093 & 259 & 259 & TBD & 491 \\
\hline oper. flow rate, $1 / h^{(b)}$ & 21.6 & 18 & 3.6 & 167 & 3.6 & 167 & 46.8 & 46.8 & 167 & 98 & 187.5 & 98 & 98 & 87 & 11 & 11 & & 20.5 \\
\hline Design flow rate, $1 / h^{(b)}$ & 43.3 & 36 & 7.2 & 334 & 7.2 & 334 & 93.7 & 93.7 & 334 & 196 & 375 & 196 & 196 & 174 & 22 & 22 & & 41 \\
\hline Heat load, $w / 1$ (c) & TBD & & & & & TBD & TBD & $T B D$ & $\mathrm{TBD}$ & TBD & TBD & & TBD & & TBD & IBD & & \\
\hline Activity, $\mathrm{C}_{1} / 1$ & TBD & & & & & TBD & TBD & TBD & TBD & TBD & TBD & & TBD & & TED & $\mathrm{TBD}$ & & \\
\hline Urantum, $g / 1$ & 0.01 & & & & & 0.001 & Trace & Trace & 0.001 & 0.001 & Neg1 & & 0.002 & & 0.015 & 0.015 & & \\
\hline Thor 1um, $g / 1$ & 232 & & & & & 30 & 0.11 & 0.11 & 30 & 51.1 & 0.027 & & 51.1 & & 464 & 464 & & \\
\hline $\mathrm{Pu}, \mathrm{g} / 1$ & 0.002 & & & & & Neg1 1 & 0.001 & 0.001 & Neg1 & Neg1 & Negl & & Neg1 & & Neg1 & Neg1 & & \\
\hline Other H.M., $\mathrm{g} / 1$ & Trace & & & & & Neg1 & Trace & Trace & Neg1 & Neg1 & Neg1 & & Negl & & Neg1 & Neg1 & & \\
\hline Fission products, g/1 & 0.001 & & & & & Neg1 & 0.0005 & 0.0005 & Neg1 & Negl & Neg1 1 & & Neg1 & & Trace & Trace & & \\
\hline $\begin{array}{l}\mathrm{HNO}_{3}, \underline{\mathrm{M}} \\
\mathrm{F}^{-}, \mathrm{M} \\
\mathrm{HCOOH}, \underline{\mathrm{M}}\end{array}$ & $\begin{array}{c}-0.1 \\
0.03\end{array}$ & 0.01 & 5.0 & & 13.0 & 0.05 & $\begin{array}{l}1.16 \\
0.014\end{array}$ & $\begin{array}{l}1.16 \\
0.014\end{array}$ & 0.05 & 0.10 & Trace & 0.01 & 0.10 & Trace & 0.5 & 0.5 & & \\
\hline $\begin{array}{l}\text { TBP-NPH, VX TBP } \\
\mathrm{Pe}^{++}, \underline{\mathrm{M}} \\
\mathrm{N}_{2} \mathrm{H}_{4}, \underline{\mathrm{M}}\end{array}$ & $\begin{array}{l}0.0035 \\
0.03\end{array}$ & 0.045 & & 30 & & 30 & $\begin{array}{l}0.019 \\
0.014\end{array}$ & & 30 & & 30 & & & & & & & 30 \\
\hline
\end{tabular}

(a) Exclusive of rework. Based on 263 equivalent operating days/yr.

(b) Based on processing 10,000 fuel elements/yr. Deelgn flow rate 18 20,000 pE/yr exclusive of excess required for rework.

(c) Decay heat only. 